Portland State University

PDXScholar

$1-1-2011$

\title{
Cultivating Environmental Stewardship in Middle School Students
}

Kelly Anne Fischer

Portland State University

Follow this and additional works at: https://pdxscholar.library.pdx.edu/open_access_etds Let us know how access to this document benefits you.

Recommended Citation

Fischer, Kelly Anne, "Cultivating Environmental Stewardship in Middle School Students" (2011).

Dissertations and Theses. Paper 560.

https://doi.org/10.15760/etd.560

This Thesis is brought to you for free and open access. It has been accepted for inclusion in Dissertations and Theses by an authorized administrator of PDXScholar. Please contact us if we can make this document more accessible: pdxscholar@pdx.edu. 
Cultivating Environmental Stewardship in Middle School Students

\author{
by \\ Kelly Anne Fischer \\ A thesis submitted in partial fulfillment of the \\ requirements for the degree of \\ Master of Science \\ in \\ Environmental Science and Management
}

Thesis Committee:

Marion Dresner, Chair

Catherine de Rivera

Candyce Reynolds

Portland State University

2011 


\begin{abstract}
Environmental stewardship is an important attribute for students and populations of all ages to have. This study looked at the effect of middle school students of a teacher who participated in a summer field ecology training program taking part in a long-term ecology project, and the impact of the experience on their environmental stewardship attitude. A variety of qualitative and quantitative techniques were used to look at changes in students' environmental stewardship attitudes including: surveying in a pre/post format, teacher, parent, and student focus groups, and teacher interviews. The teacher's experience with the summer field ecology training provided a foundation for development of curriculum and confidence in carrying out fieldwork with his students. Results indicate that participation in a long-term project contributed towards an increase in the students' environmental stewardship attitude, especially if the students reported having taken part in environmental activities in the past or if they were female. The results also indicate a number of implications for other schools and teachers including: focusing on middle school students, good teacher training, focused, long-term projects for students, support for teachers for project implementation, and ecological restoration as part of the student projects.
\end{abstract}




\section{ACKNOWLEDGEMENTS}

I would like to thank Dr. Marion Dresner, my advisor and friend, for all of her hard work, patience, and guidance in helping me complete this project.

I would like to thank all of the teachers and their students who supported me with their time and energy over the past two years, especially Pad Quinn who was invaluable throughout the entire process and really made all of this work possible.

I would like to thank Dr. Catherine de Rivera and Dr. Candyce Reynolds for all of their invested time and energy in this project.

I would like to thank Kala Gonsler, Hannah McDonald, Julie McWhorter, Kerissa Fuccillo, and Steve Braun for listening to me and helping me with data collection and sanity.

I would like to thank the National Science Foundation and the Gray Family Foundation for their financial support in this research.

Lastly, I would like to thank my loving, patient husband, Eric Fischer, and family, for their support and encouragement as this very long process draws to a close. I promise now to dedicate my full energy and attention to the two of you. 


\section{TABLE OF CONTENTS}

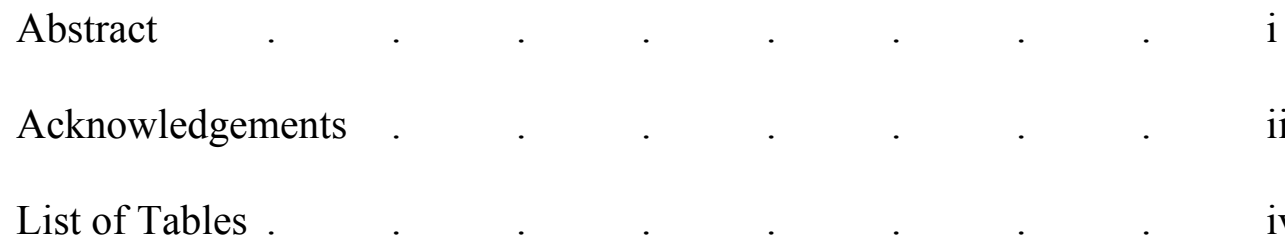

Chapter 1

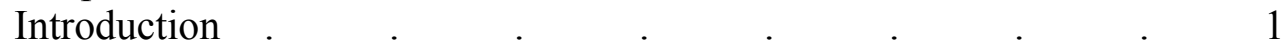

Chapter 2

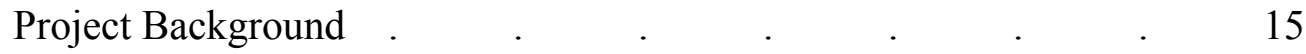

Chapter 3

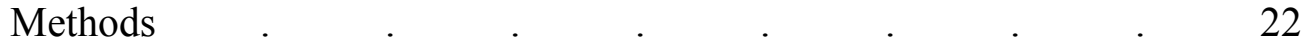

Chapter 4

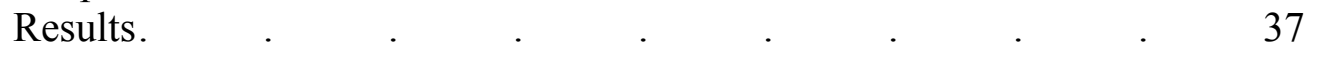

Chapter 5

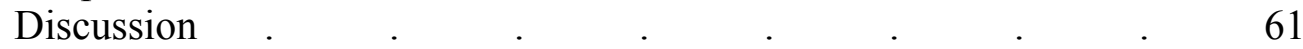

Chapter 6

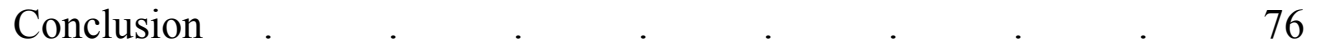

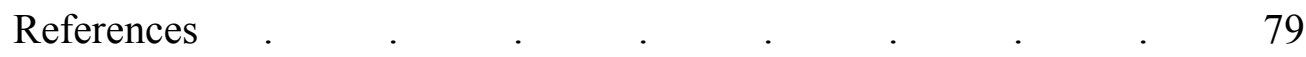

Appendices

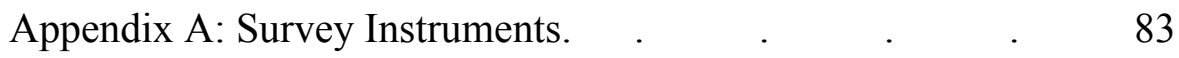

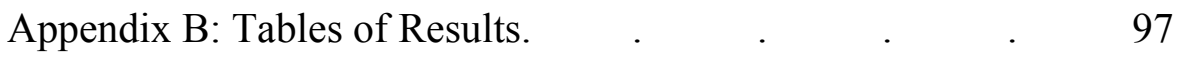

Appendix C: Human Subjects Documentation. $\quad$. $\quad$. 121 


\section{LIST OF TABLES}

3.1: Respect for the Environment Pre-Stewardship Survey Statements (Appendices

A.1 and A.4) . $\quad . \quad$. $\quad . \quad$. $\quad . \quad$. $\quad . \quad$. 24

3.2: Desire to Learn about the Environment Pre-Stewardship Survey Statements

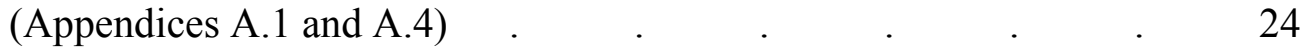

3.3: Interest in Sharing Environmental Knowledge with Others Pre-Stewardship

Survey Statements (Appendices A.1 and A.4) . . . . 25

3.4: Attachment to Place Pre-Stewardship Survey Statements (Appendices A.1 and

A.4) . . . . . . . . . . . . . . . 25

3.5: Improving Degraded Environments and Protecting the Environment Pre-

Stewardship Survey Statements (Appendices A.1 and A.4) . $\quad$. 25

3.6: Projects and Methods Listed by Teacher. $\quad . \quad$. $\quad$. 34

4.1: Year Two Experimental and Control Group Comparison based on Individual Statements Post-Stewardship Results (Appendix A.5) $(\mathrm{p}<0.05) \quad$. 39

4.2: Year One Overall Stewardship Survey Results (Appendices A.1 and A.2)

4.3: Year Two Overall Stewardship Survey (Pre/Post) Results (Appendices A.4 and A.5)

4.4: Year One Individual Statement Stewardship Survey (Pre/Post) Results (Appendices A.1 and A.2) .

4.5: Year One Pre-Stewardship Survey Areas based on Past Experiences with Environmental Activities (Appendix A.1) . $\quad$. $\quad . \quad$. $\quad 48$

4.6: Year Two Post-Stewardship Survey Areas based on Past Experiences with Environmental Activities for Experimental and FO Control Groups (Appendix A.5)

50

4.7: Year One Quinn's Class Pre/Post Stewardship Survey Areas based on Gender (Appendices A.1 and A.2)

4.8: Year One Marquardt's Class Pre/Post Stewardship Survey Areas based on Gender (Appendices A.1 and A.2) . . . . . . . 52 
4.9: Year One Carnes' Class Pre/Post Stewardship Survey Areas based on Gender (Appendices A.1 and A.2)

4.10: Year Two Post-Survey Stewardship Areas based on Gender (Appendix A.5)

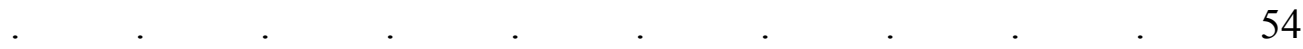

4.11: Year Two Post-Survey Stewardship Areas based on Grade for Experimental and FO Control Groups (Appendix A.5) . $\quad . \quad$. $\quad . \quad 55$

4.12: Year One Overall Science Interest Survey Results (Appendix A.3) 56

4.13: Year One Individual Statement Science Interest Survey (Pre/Post) Results

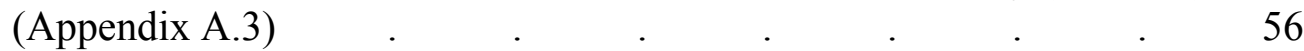

4.14: Year Two Overall Science Interest Survey (Pre/Post) Results (Appendix A.6)

4.15: Year Two Individual Statement Science Interest Survey (Pre/Post) Results

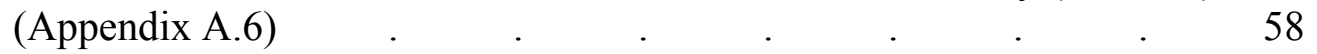

4.16: Year Two Post-Science Interest Survey Results Displayed based on Gender

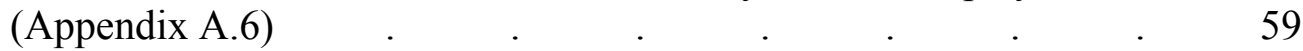

4.17: Year Two Post-Science Interest Survey Results Displayed based on Grade (Appendix A.6) 


\section{CHAPTER 1: INTRODUCTION}

Environmental stewardship is an important facet of environmental education not only for the environmental experiences that it brings about but also for the sense of duty it provokes. The natural resources of the earth are in limited supply and the obligation to protect them and the health of the planet for future generations falls to all citizens of the planet, especially the youth that will be inheriting the current and ever-changing environmental state. Without developing a strong sense of environmental stewardship early in life, it is unlikely that young people will feel a sense of obligation to protect the natural world and its ecosystems. Can first-hand ecological knowledge gained through participation in a year-long, school-based environmental monitoring program lead to heightened stewardship attitudes? This was tested at an environment-themed middle school located in Beaverton, Oregon.

\section{Environmental Stewardship}

Environmental stewardship is defined as the "duty to look after our world prudently and conscientiously" and to defend and protect ecosystems in order to be viable for future generations (Manzanal et al. 1999; Foster 2005). This responsibility can be developed at any age through a variety of experiences, from elementary school-aged students through elder zoo volunteers (Cronin-Jones 2000; Kenney et al. 2003; Fraser et al. 2009). Forms of "defending" and "protecting" vary, and may include direct participation in environmental conservation activities, such as taking part in a long-term ecology project, engaging in environmentally 
conscious behaviors, such as choosing to recycle and/or compost, and helping to educate others about the environment, such as through informing them of the consequences of their choices.

Directly measuring environmental stewardship attitudes can be a challenge because of the different ways that stewardship and attitudes are held and expressed. Attitudes can be exhibited through knowledge and behaviors, the foundation of both of which is personal values (Manfredo and Teel 2008). This study seeks to demonstrate such complexities in attitude measurement and change due to student participation in a long-term ecology project.

\section{Long-term Outcomes}

Exposing students to environmental projects when they are young can foster a love and interest in the natural world that can remain with them throughout their lives (Palmer and Suggate 1996). Undergraduate college students who report having participated in an environmental program in the past, are more likely to have a higher environmental stewardship attitude score than those students who have not (Dresner 2009). Ryan et al. (2001) also found that the more often an environmental volunteer, of any age, participates at a site, the more likely they will do so again and reap the benefits of volunteering. The benefits of volunteering include: "doing something worthwhile... gaining educational experience...[and] helping the environment" (Ryan et al. 2001, p. 630). While the volunteer gains a number of benefits, more positive aspects of the activity benefit the ecosystem being protected and/or restored (Ryan et al. 2001). This outcome is promising for 
educators (and the planet) because it has been shown to make a long-term difference by having students work on environmental issue projects. As will be shown in the literature (see Examples of Long-term Projects), long-term ecologybased projects, directed by teachers and undertaken by students, can have a profound effect on the students' environmental stewardship attitude and indirectly, their behavior. These behavior choices will hopefully remain with them, throughout their lives, and lead to better environmental protection, conservation, and appreciation as they grow older.

It is evident that there is a link between environmental experiences in youth and the resultant adult behavior and choices. In the United Kingdom, in a study by Palmer and Suggate, science educators "were asked to state...which, if any, of the years of their lives were particularly memorable in the development of positive attitudes toward the environment" (Palmer and Suggate 1996, p. 110)? The most commonly named influences involved childhood experiences of nature and involvement of family and adults' (teachers included) enthusiasm for the natural world (Palmer and Suggate 1996). A high number of respondents also noted sustainable activities as part of their daily lives (i.e. leading a "green" lifestyle, recycling, enjoying outdoor activities) (Palmer and Suggate 1996). This study again shows the importance of working with students, exposing them to environmental issues, and allowing them to develop a strong environmental stewardship attitude that can influence their behavior in the future. 


\section{The Need for More Environmental Education}

According to Coyle in 2005, "only one to two percent of adults in America can be considered environmentally literate" (Johnson and Catley 2009). This, coupled with the growing complexities of environmental problems, demonstrates the need to produce environmentally conscious citizens that care for the environment (Johnson and Catley 2009). Louv (2005, p. 3) feels that it is also important for the human environment, "How the young respond to nature, and how they raise their own children, will shape the configurations and conditions of our cities, homes - our daily lives."

One solution is the inclusion of more environmental education (EE) built into the curriculum, at all levels of education. This is currently taking shape in schools with environmental themes (i.e. Rachel Carson Environmental Middle School, Sunnyside Environmental Middle School), traditional schools offering environmental science classes (i.e. IB and AP Environmental Science classes at Beaverton High School), and inclusion of placed-based, environmental experiences as part of the school year curriculum (i.e. Outdoor School). It stands to reason that with more exposure to environmental experiences, including long-term ecology projects, students will have a better appreciation and understanding of the natural world. This appreciation and understanding will hopefully lead to improving stewardship attitudes. 


\section{Examples of Long-Term Projects}

Improving stewardship attitudes through fieldwork is both qualitatively and quantitatively measured in the current literature through a number of studies. Crawford (2000) documented a case study of a high school ecology class in the Pacific Northwest where one teacher, “Jake,” (a pseudonym) provided opportunities for his students to do original, authentic research and fieldwork for members of the local community. The students became aware of local problems and suggested solutions based on their data analysis. Crawford, as the "participantobserver" researcher, conducted semi-structured interviews with the teacher, made classroom and fieldtrip video observations, conducted random student interviews, and analyzed the results from anonymous student questionnaires given at the end of the year, in order to establish how this teacher created an inquiry-based learning environment in his classroom. All of these different types of data were summarized and coded to corroborate or refute the researcher's hypothesis and resulted in six key characteristics of Jake's ecology classroom. After working on their projects throughout the year, the students expressed greater feelings of "ownership" in their community during their concluding interviews, denoting a change in environmental stewardship attitudes.

In a study conducted in the Great Smokey Mountains National Park (GSMNP), middle and high school students and teachers were given the opportunity to experience "...connections with nature, environmental stewardship... learning and discovery, awareness of GSMNP and biodiversity" 
(Stern et al. 2008, p. 34). The majority of the program consisted of experiential and place-based learning using the national park as an outdoor classroom. A sample (not random) of the fourth through seventh grade students that took part in the program completed pre-experience, post-experience, and follow-up surveys that were each measured on a 5-point Likert-type scale and sought to measure "Connection with nature," "Environmental stewardship (stewardship)," "Interest in learning and discovery (discovery)," and "Knowledge and awareness of GSMNP and biological diversity (awareness)." The pre- and post-experience surveys were administered at GSMNP, by the staff there, and the follow-up surveys were administered by the teachers, in their classrooms, three months after the experience. The students that participated in the program had statistically significant gains in each of the components studied, especially "stewardship." Three months after the program, the measurements of "connection with nature," "stewardship," and "awareness" remained higher than the levels before the students participated in the program demonstrating the longevity in the attitude change due to the experience. Though this was a short period of time following the program, it still is promising for environmental attitude change.

A program in Pennsylvania, utilized school grounds as the fieldwork sites for kindergarten through eighth grade students to conduct research projects (Kenney et al. 2003). Lessons were designed by an outside group to make implementation easier for teachers. Groups of students were taken into their schoolyards and explored original problems and authentic solutions, such as ideas for litter control. 
The program effect on student "knowledge, skills, and attitudes were measured using surveys, tests, interviews, and focus group discussions" (Kenney et al. 2003, p. 21). Target grades were selected and tracked over a 3-year period, and given tests before and after several lessons. A random sampling of students was selected, from the target grades, for focus group discussions that were a mix of male and female, same grade level students. The resulting data show that students made statistically significant gains in environmental knowledge and anecdotally there were changes in environmental stewardship attitudes, for example: "[students] learned to better appreciate plants and animals in their environment," "students said they would tell the younger kids, 'Don't kill anything - it's part of nature,'” the students had more respect for nature and confessed to littering in the past but would not do so now because it's polluting (Kenney et al. 2003, p. 23). The teachers also reported, in their interviews, that the students now "want to pick up trash," "they are seeing the outdoor space as their own and feel more of a role or obligation in caring for it," and they tell each other what activities they should stop doing because of their impact on the natural world (Kenney et al. 2003, p. 23). By working in locally relevant spaces, the students took ownership of the areas and changed some of their own behaviors, an example of change in environmental stewardship attitudes.

A study by Cook (2008) in northern England followed Year 9 geography students (ages 13-14) and found that those who participated in fieldwork had the greatest development of their environmental stewardship attitude. Cook used a 
variety of methods including: a Likert-type survey, activities, interviews, photo elicitation, and open-ended questions to capture students' ideas and feelings toward fieldwork. A significant proportion of the students became attached to "their" fieldwork areas and stated that they would be upset if the area were destroyed. However, this example of growth was offset by a small proportion of students who viewed the fieldwork areas as important only because the study of the sites was attached to their grade for the class. From this deficiency, the importance of expressing the connection between the site and the larger ecosystem to the students, not just the importance of the final product and grade, should be noted.

Barnett et al. (2006) followed field-based ecology programs in Boston, Massachusetts, using sites within the city that the students could easily access, over a 2-year period. Different groups were given a variety of projects (e.g. avian studies, water quality, turtle ecology) on which to collect data. Those data were later presented at a yearly student research conference, validating the research done by the students. Quantitative and qualitative data were collected, via student surveys and interviews from a random sampling of the program participants (and also from a control group that did not take part in the fieldwork), in a pre/post format (the survey was slightly modified in the second year), and showed an increase in environmental stewardship in those that participated. Some of the teachers were also interviewed to gage their students' thinking towards the environment and better see if the students had a change in their level of science interest. The experimental group showed a statistically significant increase in their 
stewardship attitudes based on survey and interview data. The participating students also showed ownership of "their" site denoting a change in stewardship attitude.

Lastly, a program in Ohio designed to foster "real science" ("i.e. biomonitoring protocols of the Ohio Environmental Protection Agency") learning in $11^{\text {th }}$ and $12^{\text {th }}$ graders, has been successful in fostering stronger environmental stewardship attitudes (Taylor et al. 2008, p. 1). This opportunity allowed both teachers and students to attend a 12-day training session where the group learned how to collect data using the protocols of the Ohio Environmental Protection Agency. The information learned was then taken back to their schools and original data were collected and analyzed on the school sites. This program gave students the opportunity to become citizen scientists for their community and to assist a state government agency. The teachers and students were given surveys, kept journals, participated in discussions, participated in focus groups, gave presentations, visited websites, and took part in interviews in order to measure their knowledge of the procedures and the correct data collection method, as well as their attitudes toward science. Results from this program exhibited qualitative increases in stewardship attitudes and interest in science careers.

\section{Current Project}

Past researchers have designed a number of studies and many mention the important components necessary when measuring environmental stewardship attitudes. This current study takes suggestions from a number of researchers 
including: embodying the role of participant-observer (Crawford 2000), the use of semi-structured teacher interviews (Crawford 2000; Kenney et al. 2003; Barnett et al. 2006; Taylor et al. 2008; Cook 2008), the use of anonymous student questionnaires/surveys (Crawford 2000; Stern et al. 2008), the use of 5-point Likert-type questionnaires/surveys in a pre/post format (Barnett et al. 2006; Kenney et al. 2008; Cook 2008; Stern et al. 2008; Taylor et al. 2008), the use of middle school students (Barnett et al. 2006; Kenney et al. 2008; Cook 2008; Stern et al. 2008), having the students take part in long-term ecology project or study (Crawford 2000; Kenney et al. 2003; Barnett et al. 2006; Cook 2008; Stern et al. 2008; Taylor et al. 2008), and modification of the survey instrument between years one and two (Barnett et al. 2006). This project differs from most of the projects described above in that the teachers receive direct, specific training from scientists on how to carry out a long-term ecology project with their students. In some of the aforementioned studies, the teachers and the students either receive training together or experienced all of the stewardship building activities together. By working directly with teachers, who impact a great number of students over the course of their teaching, more individuals can be influenced to change their behaviors and environmental stewardship attitudes, which could possibly result in a life-long respect for, and action to protect, the natural world.

\section{Students as the Targeted Group}

Students will choose to care for local and global ecosystems only if they have an interest in doing so; this interest must be developed and honed. Louv 
(2005, p. 150) reports that, "The childhoods of environmentalists and naturalists are replete with stories of their childhood inspiration, leading directly to their later activism." It has been shown that middle and high school aged students that participate in fieldwork-based environmental programs, led by scientists, have a greater sense of environmental stewardship and will likely live more sustainably (Manzanal et al. 1999; Crawford 2000; Taylor et al. 2008; Johnson and Catley 2009). As discussed above, there are a number of project-based case studies demonstrating the success of improving stewardship attitudes in students.

Because today's youth will be the group sustaining our natural resources, processes and systems, and protecting the flora, fauna, and "natural capital" that support this planet, students will need to be bright and choose careers in science, technology, engineering, and math (STEM) in order to better understand and develop strategies for dealing with the complexities of the environmental future (i.e. climate change, extinctions, invasive species, human alterations to the landscape, natural materials necessary to produce capital) (Prescott-Allen 2001; Goodwin 2003; Taylor et al. 2008; Johnson and Catley 2009). Currently, the number of students in the U.S. who have successfully completed a degree in STEM fields has decreased, due to a loss of interest in science (Taylor et al. 2008). University students are switching out of STEM majors because of "a belief that other majors are more interesting," not because the students are incapable of the subject matter (Seymour and Hewitt 1997; Taylor et al. 2008, p. 2). Interest in STEM careers can be created and maintained by having students participate in 
original, fieldwork-based environmental programs that foster positive environmental concern and stewardship (Kenney et al. 2003; Barnett et al. 2006; Cook 2008; Stern et at. 2008; Taylor et al. 2008). In the current study, interest in science careers will hopefully be captured using a science interest surveying tool. Areas of Environmental Stewardship

Environmental stewardship was broken down into five areas or groupings by the author: 1. respect for the environment, 2 . desire to learn about the environment, 3. interest in sharing environmental knowledge with others, 4. attachment to place, and 5. improving degraded environments and protecting the environment. These specific groupings each come with different attributes of environmental interest, appreciation, and responsibility, as described below. It is these specific areas that the environmental stewardship surveys (Appendices A.1, A.2, A.4, and A.5), used in this project, tests for changes in.

"Respect for the environment" (respect) is a direct measure of environmental stewardship. Respect for the environment is exhibited by awareness of personal impacts made to the environment, feelings of frustration when the environment is negatively impacted, and concern about environmental health and condition (Manzanal et al. 1999; Ryan et al. 2001; Kenney et al. 2003; Bodzin 2008; Cook 2008; Stern et al. 2008).

The "desire to learn about the environment" (learn) can be viewed as another, separate part of environmental stewardship. This is exhibited by wanting to collect data on the natural world, an interest in learning more about plants and 
animals, and overall enjoyment in observing natural phenomenon (Manzanal et al. 1999; Ryan et al. 2001; Kenney et al. 2003; Barnett et al. 2006; Bodzin 2008; Stern et al. 2008).

"Sharing environmental knowledge with others" (sharing) was seen as a separate part of environmental stewardship. It is often exhibited by informing other people on recently acquired environmental knowledge, suggesting improvements to someone's incorrect environmental actions, and exposing others to natural settings (Kenney et al. 2003; Bodzin 2008).

"Attachment to place" (place) is perhaps the most documented part of environmental stewardship. It can be exhibited by wanting or choosing to spend time in nature or the outdoors, missing particular natural areas that are no longer visited, and a feeling of ownership because of a personal investment in a natural location (Manzanal et al. 1999; Ryan et al. 2001; Barnett et al. 2006; Bodzin 2008; Cook 2008). Many researchers have written about place and the feelings of attachment that it holds for people, especially natural areas (Newell 1997; Ryan 2005; Clayton and Myers 2009). The attachment to place can include affection for the place, a person's relationship to the place, and emotional ties between a person and a place and these feelings of attachment can be increased by frequently visiting that place and/or holding fond memories of the place in childhood (Ryan 2005; Clayton and Myers 2009). Louv (2005, p. 218) claims that “...place-based education increases students' sense of stewardship and environmental consciousness and adds to their sense of attachment to place." 
And, finally, "improving degraded environments and protecting the environment" (improve), a part of environmental stewardship, is most commonly thought of as stewardship. It can be exhibited by involvement in restoration or conservation activities, donation of money for environmental projects, or behavioral changes that are less destructive to the environment (Manzanal et al. 1999; Ryan et al. 2001; Kenney et al. 2003; Barnett et al. 2006; Bodzin 2008; Stern et al. 2008).

While environmental stewardship encompasses all of the different areas described above, each area has nuances that are perhaps better exhibited by some individuals than others. Breaking the large term into smaller subsets allows for the nuances to shine through and the differences within environmental stewards to be exhibited and further examined.

\section{Purpose Statement}

The purpose of this study was to measure changes in environmental attitudes of students that participated in a long-term, ecology-based project, tied to science curriculum. One key aspect of this study is the direct training that the teachers receive from scientists at the summer Teaching Ecological Complexity through Field Science Inquiry program. This study looks at a variety of qualitative and quantitative environmental stewardship and science interest data, collected over two school years, on students that take part in such long-term ecology projects. 


\section{CHAPTER 2: PROJECT BACKGROUND}

The Teaching Ecosystem Complexity through Field Science Inquiry (TEC) is a teacher professional development program funded by the National Science Foundation and led by Portland State University. The collaboration includes personnel from universities and staff from Long Term Ecological Research sites (LTERs). The aim of the program is to increase teacher content knowledge and confidence in teaching ecosystem complexity using field studies and scientific inquiry. The teachers that attend have opportunities to learn directly from scientists, experience their work, assist in their research, and rely on their mentoring while doing their own research. A website, Ecoplexity (www.ecoplexity.org), was developed to serve as a major resource for students and teachers throughout the summer program and during the school year.

The TEC summer ecology training programs were held between 2007 and 2010. At these summer programs, life science teachers learned how to carry out long-term, ecology projects with their students. During the following school year, the teachers were expected to implement student projects and received project implementation help from graduate students. Graduate students helped collect the following data on the teachers and students: teacher classroom practices (including teacher confidence in teaching ecology), student interest in science, and student stewardship attitudes. These data were collected in a pre/post format. Classroom practices were assessed before and after the teachers took part in the summer workshop, as well as after the teachers carried out their long-term projects in the 
classroom. Student surveys were conducted before and after the students took part in their long-term ecology projects.

\section{Year One (2009-2010 School Year) Background: Summer Program}

Ten teachers worked in different groups, along-side scientists, on different inquiry-based ecology projects, including moth studies, leaf-litter decomposition studies, and invertebrate pit-fall trap studies, over a 2-week period in the summer at the HJ Andrews Experimental Forest LTER. For each in-depth research project, teachers worked through the scientific method by creating a hypothesis, collecting and analyzing data, interpreting the statistical results, and communicating their findings in a research paper or poster. Frequent presentations and group discussions helped to build knowledge of scientific ideas and connected those ideas to the research project. Teachers remained at the site during the 2-weeks of the workshop, which afforded them a greater depth of experience. The result was better teacher "preparedness to: teach using fieldwork, conduct long-term experiments, pose a hypothesis, and collect data," with their students (responses from the exit surveys at the conclusion of the workshop and conformation of results by graduate student

observations). It was expected that the teachers in attendance would participate in a fieldwork-based ecology project, during the 2009-2010 school year, with their students.

It was expected that the students who participated in ecology data collection in the field would have a change in their environmental attitudes and stewardship. With this better understanding of and work in natural spaces, students may live 
more sustainability in the future and make more environmentally conscious decisions.

\section{Year Two (2010-2011 School Year) Background: Summer Program}

Seven teachers (one repeating teacher from Year One) worked in different groups, along-side scientists, on different inquiry-based ecology projects, including vertebrate studies, long-term forest plot installation and vegetation studies, and invertebrate pit-fall trap studies, over a 2 -week period in the summer in two locations in Forest Park (the invertebrate group collected data in the Coast Range, as well) in Oregon. The teachers did not remain on site for the full 2-weeks, given the close proximity to home. It was expected that the teachers in attendance would participate in a fieldwork-based ecology project, during the 2010-2011 school year, with their students.

\section{Outcomes of the Summer TEC Program}

Teacher outcomes of the summer program include:

1. Increased teacher knowledge of ecological content and modeling: According to teachers' evaluations and pre/post-surveys, the workshops were very successful in increasing their knowledge of ecological content.

2. Improved teacher skills in teaching through field methods: According to teachers' evaluations and pre/post-surveys, the workshops were very successful in increasing their knowledge of and ability to carry out field research. Many teachers responding to the year-end, online survey described how they engaged 
students in field-based research assignments using protocols from the Ecoplexity website.

3. Improved pedagogical skills in teaching through inquiry: There is evidence from the teacher practices pre/post-surveys that teacher confidence in doing field studies and research with students, and a few aspects of science inquiry activities with students, did change.

4. Increased interest in science and understanding of ecological complexity and scientific inquiry by students of teachers involved in summer program: There is evidence that students had increased opportunities to learn about the environment and ecology because of the training their teachers had received.

The above outcomes of the program demonstrate the quality of the program being offered and the increased confidence in inquiry-based science teaching. I am investigating the relationships between exposure to these long-term ecological research projects and environmental stewardship attitudes in students. This study on student stewardship attitudes falls under the larger TEC program. The two studies were carried out in conjunction with one another and called upon many of the same researches (i.e. graduate students, professors, participating teachers, participating students).

\section{Year One Background: Participants and Projects}

Of the 10 teachers that took part in the 2009 summer training, only 4 completed both pre- and post-survey measures of their students. The ecology projects that the students collected, analyzed, and reported data on varied 
depending on the interest, resources, and available time of the students and teacher. These 4 teachers (Quinn, Cooper, Marquardt, and Carnes) carried out a variety of projects, including: invasive species removal and percent cover studies, leaf-litter decomposition rate studies, and pit-fall trapping of invertebrate studies.

Quinn teaches integrated science at Rachel Carson Environmental Middle School in Beaverton, Oregon and has a background in environmental consulting. The students that attend this options school are in grades 6-8. The project was run with Quinn's homeroom, seventh grade students. The project was made of a number of studies of a natural area on the school grounds including: pitfall trapping, counting, and identifying invertebrates, invasive species identification and removal, and phenology monitoring of different trees.

Cooper teaches biology and IB environmental studies at Beaverton High School in Beaverton, Oregon. The students that attend this traditional high school are in grades 9-12. The project was run with Cooper's EcoClub, an after school group made up of some of her students and others from the school. The students that participated were in grades $10-12$. One difficulty this teacher ran into was having the same students take the pre- and post-surveys, and be the same students participating in the long-term project throughout the year. The project included taking percent cover readings in both in the fall and spring of an area in Forest Park, removing invasive English ivy, and planting and analyzing leaf-litter bags. Marquardt teaches general biology at Wilson High School in Portland, Oregon. The students that attend this traditional high school are in grades 9-12. 
The project was carried out by all of Marquardt's $9^{\text {th }}$ grade biology classes. The project the group carried out worked in conjunction with the Bureau of Environmental Services and the students visited, learned different water quality sampling methods, took samples, analyzed results, and did restoration work at 3 different local creeks.

Carnes teaches a variety of science and health classes at Century High School in Hillsboro, Oregon. The students that attend this traditional high school are in grades 9-12. The project was carried out mainly by her $9^{\text {th }}$ and $10^{\text {th }}$ graders and included a self-chosen inquiry project. Some of the projects included bird, lichen, soil, tree, and plant studies.

\section{Year Two Background: Participant and Project}

One teacher was followed and his students were monitored for changes in stewardship attitudes, for this project. Because of demonstrated commitment to the program, Quinn, was chosen to be closely monitored. All of the other summer program attendees were given support in the implementation of their long-term projects.

Quinn continues to teach integrated science at Rachel Carson Environmental Middle School, an options school, in Beaverton, Oregon. The project was run with all of Quinn's students, grades 6-8. The project was made of a number of studies of a natural area on the school grounds including: identifying, tagging, and taking baseline information on trees, coring a number of sample trees, invasive species identification and removal, and phenology monitoring of different 
trees and plants. The group of students also made numerous visits to Willow Creek, near their school, and took part in restoration work there, as part of the SOLV program. The projects took place over the length of the school year. The school also provides numerous opportunities for students to make visits to different environmental sites throughout the year. 


\section{CHAPTER 3: METHODS}

\section{Year One: Stewardship Survey}

Measuring environmental stewardship attitudes in students has been used by Ryan et al. (2001) and helped to direct the development of the initial 15 question stewardship surveys used in this study (Appendices A.1 and A.2). Each statement meant to capture how the student felt towards that specific aspect of the environment. This survey was measured on a 4-point Likert-type scale. The students took a similar survey at the conclusion of their project, the poststewardship survey (Appendix A.2). Each response option was given a corresponding point value in order to calculate stewardship scores. The response choices and point values (in parenthesis) included:

- $\quad$ Definitely NOT true for me (1)

- True for me once and a while (2)

- $\quad$ Sometimes true for me (3)

- Definitely TRUE for me (4)

The survey also asked for gender, grade level, and if the student had participated in ecological fieldwork in the past. Two statements were written in reverse (example: I don't really like discovering animals or plants while outdoors) and their point value was likewise calculated in reverse. The survey was used with a variety of students in Year One.

\section{Year Two: Stewardship Survey}

For Year Two, the survey was based on the 15-question pre-stewardship survey (Appendix A.1) given in Year One but removed certain questions and added a variety of others, increasing the total number to 30 questions, in order to more 
fully capture changes in stewardship attitudes (Appendix A.4). The scale was also increased to a 5-point Likert-type scale with responses and point values (in parenthesis) including:

- $\quad$ Definitely NOT true for me (1)

- $\quad$ I might (2)

- $\quad$ Sometimes (3)

- Often (4)

- Definitely true for me (5)

Changing the survey from 4- to 5- response options is more in line with the literature. Though because of these survey changes, there could be a problem with the validity of the instrument.

Personal questions like gender and if the student had ever helped to restore or had conducted research in natural areas before this class were also included on the survey. The students took a similar survey at the conclusion of their project, the post-stewardship survey (Appendix A.5). Three statements on the survey were written in reverse and their point values were likewise calculated in reverse. The survey was used with a variety of middle school students in Year Two.

\section{Areas of Environmental Stewardship}

Environmental stewardship has been broken into five areas or groupings: 1 . respect for the environment, 2. desire to learn about the environment, 3 . interest in sharing environmental knowledge with others, 4. attachment to place, and 5. improving degraded environments and protecting the environment. These specific groupings each come with different attributes of environmental interest, appreciation, and responsibility, as described above. It is these specific areas that 
the environmental stewardship surveys (Appendices A.1, A.2, A.4, and A.5), used in this project, tests for changes in. The following tables give specifics on which questions from the pre-stewardship surveys are grouped into each of the stewardship areas. Note that some statements have been slightly modified on the post-stewardship surveys.

Table 3.1: Respect for the Environment Pre-Stewardship Survey Statements (Appendices A.1 and A.4)

\begin{tabular}{|l|l|}
\hline \multicolumn{1}{|c|}{ Year One Survey Statements } & \multicolumn{1}{c|}{ Year Two Survey Statements } \\
\hline $\begin{array}{l}\text { 4. I feel that natural areas, like parks, } \\
\text { preserves, wildlife refuges, are important. }\end{array}$ & $\begin{array}{l}\text { 18. I am more aware of my impacts to the } \\
\text { natural environment (than before). }\end{array}$ \\
\hline $\begin{array}{l}\text { 14. I feel a strong emotional connection to } \\
\text { natural areas. }\end{array}$ & $\begin{array}{l}\text { 19. I get upset when I learn about the } \\
\text { destruction of natural areas, even if they are far } \\
\text { away. }\end{array}$ \\
\hline & $\begin{array}{l}\text { 23. When I am on a trail, I try not to go off } \\
\text { trail. }\end{array}$ \\
\hline & $\begin{array}{l}\text { 30. I am concerned about present conditions in } \\
\text { Forest Park and about how it can be preserved. }\end{array}$ \\
\hline
\end{tabular}

Table 3.2: Desire to Learn About the Environment Pre-Stewardship Survey Statements (Appendices A.1 and A.4)

\begin{tabular}{|l|l|}
\hline \multicolumn{1}{|c|}{ Year One Survey Statements } & \multicolumn{1}{c|}{ Year Two Survey Statements } \\
\hline $\begin{array}{l}\text { 3. I don't really like discovering animals or } \\
\text { plants while outdoors. (Statement in reverse) }\end{array}$ & $\begin{array}{l}\text { 3. I don't really like finding signs of animals or } \\
\text { learning about the plants, while I am outdoors. } \\
\text { (Statement in reverse) }\end{array}$ \\
\hline $\begin{array}{l}\text { 15. I like to learn about natural ecosystems, the } \\
\text { plants and animals that live in them. }\end{array}$ & $\begin{array}{l}\text { 11. I think it will be fun to collect data in a } \\
\text { natural area. }\end{array}$ \\
\hline & $\begin{array}{l}\text { 14. I think that by collecting data, better } \\
\text { management decisions about a natural area can } \\
\text { be made. }\end{array}$ \\
\hline & $\begin{array}{l}\text { 15. I like to learn about natural ecosystems, the } \\
\text { plants and animals that live in them. }\end{array}$ \\
\hline & $\begin{array}{l}\text { 17. I can recognize unhealthy landscapes (like } \\
\text { ones with invasive species). }\end{array}$ \\
\hline & $\begin{array}{l}\text { 20. I try to seek out more information about } \\
\text { the natural world whenever I can. }\end{array}$ \\
\hline & 26. I enjoy observing things in nature. \\
\hline &
\end{tabular}


Table 3.3: Interest in Sharing Environmental Knowledge with Others PreStewardship Survey Statements (Appendices A.1 and A.4)

\begin{tabular}{|l|l|}
\hline \multicolumn{1}{|c|}{ Year One Survey Statements } & \multicolumn{1}{c|}{ Year Two Survey Statements } \\
\hline $\begin{array}{l}\text { 2. I enjoy talking to my friends and/or family } \\
\text { about what I'm doing in science class. }\end{array}$ & $\begin{array}{l}\text { 2. I enjoy talking to my friends and family } \\
\text { about what I'm doing in science class. }\end{array}$ \\
\hline $\begin{array}{l}\text { 13. I think I would bring family and friends to } \\
\text { the natural area where I worked to show them } \\
\text { around. }\end{array}$ & $\begin{array}{l}\text { 13. I would show the natural area where I } \\
\text { worked to my friends and/or family, if I have a } \\
\text { chance. }\end{array}$ \\
\hline & $\begin{array}{l}\text { 25. People are often surprised about how many } \\
\text { species I can identify in natural areas. }\end{array}$ \\
\hline & $\begin{array}{l}\text { 29. I actively advocate for conservation by } \\
\text { talking to others. }\end{array}$ \\
\hline
\end{tabular}

\section{Table 3.4: Attachment to Place Pre-Stewardship Survey Statements} (Appendices A.1 and A.4)

\begin{tabular}{|l|l|}
\hline \multicolumn{1}{|c|}{ Year One Survey Statements } & \multicolumn{1}{c|}{ Year Two Survey Statements } \\
\hline $\begin{array}{l}\text { 1. When I can, I go outdoors to natural } \\
\text { environments in my free time. }\end{array}$ & $\begin{array}{l}\text { 1. I go outdoors to natural environments in my } \\
\text { free time whenever I can. }\end{array}$ \\
\hline $\begin{array}{l}\text { 7. I would be upset if a natural area where I } \\
\text { worked was destroyed. }\end{array}$ & $\begin{array}{l}\text { 4. I feel a strong attachment to particular } \\
\text { natural places. }\end{array}$ \\
\hline $\begin{array}{l}\text { 8. I think you can get along fine in every day } \\
\text { life without spending time in nature. }\end{array}$ & $\begin{array}{l}\text { 8. I think you can get along fine without } \\
\text { spending time in nature. (Statement in } \\
\text { reverse) }\end{array}$ \\
\hline $\begin{array}{l}\text { 10. If I had to move away, I would miss the } \\
\text { natural areas I had visited near my home or } \\
\text { school. }\end{array}$ & $\begin{array}{l}\text { 10. If I had to move away, I would miss the } \\
\text { natural areas where I have visited with my } \\
\text { class. }\end{array}$ \\
\hline & 16. I like the chance to be outdoors. \\
\hline & 24. I feel at home when I am in natural areas. \\
\hline
\end{tabular}

Table 3.5: Improving Degraded Environments and Protecting the Environment Pre-Stewardship Survey Statements (Appendices A.1 and A.4)

\begin{tabular}{|l|l|}
\hline \multicolumn{1}{|c|}{ Year One Survey Statements } & \multicolumn{1}{c|}{ Year Two Survey Statements } \\
\hline $\begin{array}{l}\text { 5. I am making a meaningful contribution to } \\
\text { helping the environment in this project. }\end{array}$ & $\begin{array}{l}\text { 5. I think that I am going to help the } \\
\text { environment through our project in science } \\
\text { class. }\end{array}$ \\
\hline $\begin{array}{l}\text { 6. I would like to help (or have already helped) } \\
\text { create natural areas/landscapes at home. }\end{array}$ & $\begin{array}{l}\text { 6. I would like to help restore or study natural } \\
\text { areas in my community. }\end{array}$ \\
\hline $\begin{array}{l}\text { 9. I think I would help protect a natural area if } \\
\text { I had a chance to work there. }\end{array}$ & $\begin{array}{l}\text { 7. I would not give \$15 of my own money to } \\
\text { help the environment. (Statement in reverse) }\end{array}$ \\
\hline $\begin{array}{l}\text { 11. I would like to do restoration work in a } \\
\text { local natural area. }\end{array}$ & $\begin{array}{l}\text { 9. I think people can do something helpful for } \\
\text { the natural world. }\end{array}$ \\
\hline $\begin{array}{l}\text { 12. I would like to help protect natural areas in } \\
\text { other parts of the country. }\end{array}$ & $\begin{array}{l}\text { 12. I think my work in natural areas is doing } \\
\text { something useful. }\end{array}$ \\
\hline & $\begin{array}{l}21 . \text { I write letters to elected officials about } \\
\text { environmental issues. }\end{array}$ \\
\hline & $\begin{array}{l}22 . \text { I have encouraged my family to change } \\
\text { their energy use. }\end{array}$ \\
\hline & $\begin{array}{l}27 . \text { I think my work in natural areas will result } \\
\text { in improvements in environmental conditions. }\end{array}$ \\
\hline & $\begin{array}{l}28 . \text { I like the feeling of doing something } \\
\text { useful. }\end{array}$ \\
\hline & 25 \\
\hline
\end{tabular}


These areas of stewardship provide a variety of areas in which a student may have a change in attitude and were measured in both Year One and Year Two using the stewardship surveys in a pre- and post-project format.

\section{Graduate Student Participation}

Two graduate students served as a support for project implementation for the teachers. They met the teachers at the summer workshop and then stayed in contact with them throughout the school year. The graduate students served a support system for the teachers in ways of lesson ideas, providing supplies, and as an expert for students to interact with as they carried out their projects. Via email,

phone calls, and meetings, the teacher and the graduate student built both a rapport and relationship with one another. With this bond established, past experience has shown that the teacher is more likely to include the graduate student in more lessons, fieldwork, and planning and also to be more honest about barriers, challenges, and successes encountered along the way. The method of using graduate students for teacher support has also been seen in the research of Taylor et al. (2008). Participant observers have also been used in the research of Crawford (2000) and Bodzin (2008), among others.

\section{Year One: Student Measures}

Before the students began their fieldwork projects, the students completed the anonymous, 15 question science interest survey (Appendix A.3). This survey measured their overall interest in the field of science and their likelihood of entering a STEM field in the future. The survey was measured on a 3-point Likert 
scale with response choices ranging from "Definitely NOT true for me" to "Definitely TRUE for me." At the completion of the project, the students took the science interest survey again and changes were measured. The survey also asked for gender and grade level of the student. Since the survey was completed anonymously, the changes in variables were measured class-wide, not on an individual student basis.

Also before the students began their fieldwork projects, the students completed the 15 question pre-stewardship survey (Appendix A.1), anonymously, to measure their starting attitudes towards their local environment and their willingness to protect it. The changes in student scores were measured and the results were analyzed. Since the survey was anonymous, the changes in variables were calculated class-wide, not on an individual student basis. The use of surveys with students to measure changes in stewardship attitudes have been used by other researchers including: Crawford (2000), Palmburg and Kuru (2000), Kenney et al. (2003), Barnett et al. (2006), Bodzin (2008), Cook (2008), Stern et al. (2008), and Taylor et al. (2008), among others.

Student environmental stewardship was also qualitatively monitored by graduate student observations and interactions with the students. Anecdotes of support for the natural world and specific actions that students took to live more sustainably were noted. 


\section{Year One: Student Symposium}

At the close of the school year, after the projects were completed, the teachers were given the opportunity to bring some student representatives to a Student Symposium where the students were able to share their project findings with members of the university community and the public. This validated the work carried out by the students and allowed the students and teachers to show what had been learned over the course of the year. Informally during the Symposium, graduate students were able to ask the students about their projects and the possible effects that they had on their environmental stewardship attitudes. Some of the questions included:

- What have you learned about human impacts on the natural ecosystems?

- What changes have you made at home to lessen your impact on the natural world?

- Do you now feel differently about the site that you worked at?

Similar questions were also asked of parents that attended the Student Symposium to see if they had noticed any changes in their child due to their taking part in a fieldwork project. Other researchers have used open-ended questions with students, including: Manzanal et al. (1999), Crawford (2000), Barnett et al. (2006), Bodzin (2008), Cook (2008), and Taylor et al. (2008), among others.

After the students and members of the public left, the second half of the day consisted of a post-project focus group with the teachers and graduate students.

Some of the questions posed to the teachers included:

- What did you observe about your students during instruction/research that we [graduate students] might have missed? 
- Have the students reported any changes made at home (recycling, visiting natural areas more often, conserving energy, recommending changes to their parents, etc.) because of their fieldwork experiences/material learned in class?

- Have your students verbally demonstrated any changes in stewardship attitudes toward the environment?

- Did you notice a change in your students' fieldwork abilities?

Any additional information needed from the teachers, or questions that needed to be answered regarding specific activities for individual teachers, was done through individual, follow-up interviews. The responses of the questions to the students, parents, and teachers were recorded by hand and then divided into the five areas of environmental stewardship. The use of open-ended, semi-structured interview questions has been used with teachers by other researchers including: Crawford (2000), Kenney et al. (2003), Bodzin (2008), and Taylor et al. (2008), among others.

\section{Year Two: Student Measures}

Before the students began their fieldwork projects, the students completed an anonymous, 15 question science interest survey (Appendix A.6). This survey was very similar to the one used in Year One and measured the students' overall interest in the field of science and their likelihood of entering a STEM field in the future. The survey was measured on a 5-point Likert scale (a change from the 3point scaled used in the past) with response choices ranging from "Never true for me" to "Always true for me." The survey also asked for grade level and gender. At the completion of the project, the students took the science interest survey again 
and changes were measured. Since the survey was anonymous, the changes were measured class-wide, not on an individual student basis.

Also before the students began their fieldwork projects, the students completed the 30-question pre-stewardship survey (Appendix A.4), anonymously, to measure their starting attitudes toward their local environment and their willingness to protect it. The changes in student scores were measured and the results were analyzed (see Years One and Two: Survey Analysis - Stewardship). Since the survey was anonymous, the changes were calculated class-wide, not on an individual student basis. The use of surveys with students to measure changes in stewardship attitudes have been used by other researchers including: Crawford (2000), Palmburg and Kuru (2000), Barnett et al. (2006), Kenney et al. (2003), Bodzin (2008), Cook (2008), Stern et al. (2008), and Taylor et al. (2008), among others.

A random sampling of the in the experimental group participated in focus groups before and after their projects. Before the project, 22 students, 17 males and 5 females, grades 6 and 8 , were randomly selected and took part in the focus groups (4 were held with no more than 6 students each) over their lunch period of approximately 25 minutes. The students were all asked the same questions and then each was given a chance to respond. After the project, a random sampling was again taken and 18 students, 8 females and 10 males, grades 6,7 , and 8 , took park in the focus groups ( 3 were held with no more than 6 students each) of the same time and format as before. These groups consisted of a maximum of 6 students 
each, of the same grade level, who returned a permission form (approximately $98 \%$

positive response return rate). The focus groups were facilitated by a graduate student and the following questions were asked:

- Do you share or teach what you learn about the environment with other people? Who?

- Are there specific natural areas, places that you frequency visit (or would if you could on your own), which you enjoy? Where?

- Outside of what you do in school, what specific activities do you do so that you can help the environment?

- How does helping the environment help your community/neighborhood?

- What things have you learned in science class that have changed how you behave or changed how you feel towards the environment?

- Other thoughts about the environment and why we learn about it?

The comments were recorded by hand and collected anonymously with no names written down. The grade level of the group, the number of participants, and the ratio of males and females was noted. The responses were coded for areas of stewardship.

\section{Year Two: Control Group}

Rachel Carson Environmental Middle School (RCMS), an environmentallythemed middle school, is nested within Five Oaks Middle School (FOMS), a traditional middle school, in Beaverton, Oregon. The students and teachers have access to the same campus amenities (school forest, wetlands nearby, etc.). As a control, 4 classes (1 from RCMS and 3 from FOMS) that were taught by teachers who did not participate in the summer training program were also measured. 3 of the control classes, Five Oaks control (FO control), did not take part in long-term ecology based projects during the school year. These classes took only the postsurveys to measure their science interest and environmental stewardship attitudes. 
1 control class, Rachel Carson control (RC control), did take part in all of the same projects, lessons, and activities as the experimental class. The results of all of the control groups were compared to the experimental group (Quinn's class).

All of the participating teachers (control and experimental) were asked, through email, a series of questions about what they feel could influence their students' stewardship attitudes. The questions included:

- What activities that your students have taken part in so far this school year may have contributed to their stewardship attitude?

- Have you seen your students share or teach with they have learned about the environment with other people? Who? Examples?

- Do your students speak of specific natural places that they like to visit? Which places? Is there a sense of pride?

- What changes have your students made outside of school (at home, in their community, etc.) because of their environmental work? Either reported from the students or their parents?

- Do you have any specific anecdotes of stewardship examples from your students?

- If applicable, please give me a detailed explanation of your long-term ecology projects you have carried out with your students (duration, work the students did, where the project took place, etc.)

While not all teachers responded, those that did had impressive work that they had done with their students (Appendix B.7).

\section{Year Two: Parent Focus Groups}

Informal focus groups were held with parents at the end of the school year. The parents were preparing to supervise field visits for the students of RCMS. Though there was a lot of coming and going, approximately 15 parents were present for the focus group questions. The parents also talked with the researched on the site visits. The questions asked of the parent focus group included 
speculation on what could account for their child's stewardship attitude including

both factors occurring in school and at home (Appendix B.6):

- What changes have you seen in your child that you think are linked to the work and projects they take part in at this school?

- Specifically, has your child suggested changes your family should make in regards to changing energy usage, recycling, composting, changing modes of transportation, planting different plants (removing invasives, planting natives), etc.?

- Are there activities that your family took part in before your child came to RCMS that could have supported their environmental attitude? How do you encourage environmental behaviors at home?

- Have you noticed a change in the amount of time your child spends or wants to spend outdoors?

- Does your child teach you about what they learn in school? What specifically?

- Can you attribute and of the changes you have seen in your child to the projects they do in school that you may not have mentioned beforehand? Specific examples.

- What does your child want to be when they grow up? 
Table 3.6: Projects and Methods Listed by Teacher

\begin{tabular}{|c|c|c|c|c|}
\hline Teacher & Year & $\begin{array}{l}\text { Grade } \\
\text { Level }\end{array}$ & Projects & Methods/Instruments \\
\hline Quinn & One & 7 & $\begin{array}{l}\text { Pitfall trapping, } \\
\text { invasive species, } \\
\text { phenology }\end{array}$ & $\begin{array}{l}\text { Pre/Post stewardship survey, Pre/Post } \\
\text { science interest survey, Post student focus } \\
\text { group, Post parent focus group, Post teacher } \\
\text { focus group, graduate student participation, } \\
\text { teacher interviews }\end{array}$ \\
\hline Cooper & One & $10-12$ & $\begin{array}{l}\text { Percent cover, } \\
\text { invasive species, } \\
\text { leaf-litter }\end{array}$ & $\begin{array}{l}\text { Pre/Post stewardship survey, Pre/Post } \\
\text { science interest survey, Post student focus } \\
\text { group, Post parent focus group, Post teacher } \\
\text { focus group, graduate student participation, } \\
\text { teacher interviews }\end{array}$ \\
\hline Marquardt & One & 9 & Water quality & $\begin{array}{l}\text { Pre/Post stewardship survey, Pre/Post } \\
\text { science interest survey, Post student focus } \\
\text { group, Post parent focus group, Post teacher } \\
\text { focus group, graduate student participation, } \\
\text { teacher interviews }\end{array}$ \\
\hline Carnes & One & $9-10$ & Open inquiry & $\begin{array}{l}\text { Pre/Post stewardship survey, Pre/Post } \\
\text { science interest survey, Post student focus } \\
\text { group, Post parent focus group, Post teacher } \\
\text { focus group, graduate student participation, } \\
\text { teacher interviews }\end{array}$ \\
\hline Quinn & Two & $6-8$ & $\begin{array}{l}\text { Baseline tree data, } \\
\text { invasive species, } \\
\text { phenology, SOLV } \\
\text { restoration at } \\
\text { Willow Creek, } \\
\text { environmental site } \\
\text { visits }\end{array}$ & $\begin{array}{l}\text { Pre/Post stewardship survey, Pre/Post } \\
\text { science interest survey, Pre/Post student } \\
\text { focus group, Post parent focus group, } \\
\text { graduate student participation, teacher } \\
\text { interviews }\end{array}$ \\
\hline RC Control & Two & $6-8$ & $\begin{array}{l}\text { Baseline tree data, } \\
\text { invasive species, } \\
\text { phenology, SOLV } \\
\text { restoration at } \\
\text { Willow Creek, } \\
\text { environmental site } \\
\text { visits }\end{array}$ & $\begin{array}{l}\text { Pre/Post stewardship survey, Pre/Post } \\
\text { science interest survey }\end{array}$ \\
\hline $\begin{array}{l}6^{\text {th }} \text { Grade } \\
\text { FO Control }\end{array}$ & Two & 6 & None & $\begin{array}{l}\text { Post stewardship survey, Post science } \\
\text { interest survey }\end{array}$ \\
\hline $\begin{array}{l}7^{\text {th }} \text { Grade } \\
\text { FO Control }\end{array}$ & Two & 7 & None & $\begin{array}{l}\text { Post stewardship survey, Post science } \\
\text { interest survey }\end{array}$ \\
\hline $\begin{array}{l}8^{\text {th }} \text { Grade } \\
\text { FO Control }\end{array}$ & Two & 8 & None & $\begin{array}{l}\text { Post stewardship survey, Post science } \\
\text { interest survey }\end{array}$ \\
\hline
\end{tabular}

Years One and Two: Survey Analysis - Stewardship

Paper copies of the surveys were collected from the teachers and the data

were coded (for example: if a student answered "Definitely true for me" on a

regular statement, a score of 5 was given for that statement). If there was a missing 
answer, the item was left blank in the Excel program. If a statement had multiple answers, an average was taken and entered in the Excel program. If the averaged answer was a whole number, the program used the information for calculations, if it was not a whole number, it was not part of the frequency table calculations and it was considered a blank cell. The non-whole numbers were used for mean and t-test calculations.

From the raw data, frequency tables were created on a per question, per teacher basis. Each of the tables contained the number of students to answer in a similar fashion and the percent of the whole (for example: male $=14(53.8 \%)$, female $=10(38.5 \%)$, blank/unanswered/non-whole number response $=2(7.7 \%))$ as well as the total number of responses (n). For each of the true survey statements, a similar frequency table was created. The data for each statement for each teacher included: the code (1-4 for the Year One survey and 1-5 for the Year Two survey), the response items ("Definitely not true for me" to "Definitely true for me"), the frequency and percentage of each of the response items, the frequency and percentage of blank/unanswered statements, the total number of responses (n), the average answer (mean), the standard deviation, and the variance. If the teacher completed both pre- and post-surveys, the two tables were placed side-by-side and the change in the average answers was calculated.

Further analysis was done running one-tailed distribution, homoscedastic ttests of the data looking for changes in mean scores of statistical significance $(p<0.05)$ on classes that completed both the pre- and post-surveys (Barnett et al. 
2006). Similar t-tests were also run comparing mean answers given between experimental and control groups. The stewardship data were further analyzed to look for statistically significant changes in scores based on the five areas of environmental stewardship. One-tailed distribution, homoscedastic t-tests were run comparing the five groupings using pre- and post-surveys of the same teacher, males and females of the same teacher, positive and negative responses to the presurvey question(s), and grade level significance of the experimental with the control groups (Barnett et al. 2006).

\section{Years One and Two: Survey Analysis - Science Interest}

Science interest surveys from both years were analyzed in a similar fashion as the stewardship surveys. Paper copies of the surveys were collected from the teachers and the data were coded and entered into Excel. From the raw data, frequency tables were created on a per teacher, per question basis. If the teacher completed both pre- and post-surveys, the two tables were placed side-by-side and the change in the average answers was calculated. Further analysis was done running one-tailed distribution, homoscedastic t-tests of the data looking for changes in mean scores of statistical significance $(p<0.05)$ on classes that completed both the pre- and post-surveys (Barnett et al. 2006). Similar t-tests were also run comparing mean answers given between experimental and control groups. The science interest data was not broken down further into areas or groupings, like the stewardship data. 


\section{CHAPTER 4: RESULTS}

\section{Summary of Students' Science Experiences: Experimental and Control Groups}

The experimental teacher reported (Appendix B.7) having his science classes take part in tree-tagging, plant measuring and identification, and a number of site visits including Hoyt Arboretum, Steigerwald Refuge, and Willow Creek with SOLV, among others. His students had also taken part in a number of individual projects, many of which had environmental themes (i.e. ocean pollution, wolf habitat, turtles and metro greenspaces). His students talked proudly of going back to specific sites to show friends and family the work that they had done there. The students often reported to the teacher removing invasive species from their yards as well as organizing beach cleanups and ivy pulls for other students. The students in the RC control class took part in all of the same activities listed above but under the guidance of a different lead, science teacher.

The $6^{\text {th }}$ grade FO control teacher reported (Appendix B.7) that her students had not yet begun their ecology unit and therefore would not have experienced any science lessons that would influence their stewardship attitudes. In April, for Earth Day, she does have a garbage pick-up planned around the school grounds. The $7^{\text {th }}$ grade FO control teacher listed (Appendix B.7) a number of projects and activities that could have influenced his students' stewardship attitudes including: plant, bird, and wildlife studies, tree planting, and wetland monitoring. He has included a

number of outdoor learning experiences for his students into his science curriculum 
and feels this could influence their stewardship attitudes. The $8^{\text {th }}$ grade FO control teacher was unresponsive to questions asked.

\section{Stewardship Survey Results}

Attending an environmentally themed middle school impacted the students' environmental stewardship attitudes. When the post-stewardship surveys (Appendix A.5) were compared on a statement-by-statement basis, the results showed that the experimental group had statistically significant higher results than the FO controls on nearly every statement (Table 4.1). The results of the research also yield a statistically significant change in the stewardship surveys scores in the areas of: overall stewardship effects on the experimental class, past environmental experience, and gender, for many of the classes surveyed. These areas of change were often supported by responses from focus groups. The stewardship surveys, when grouped by grade, are not statistically convincing. 
Table 4.1: Year Two Experimental and Control Group Comparison based on Individual Statements Post-Stewardship Survey Results (Appendix A.5) $(\mathbf{p}<\mathbf{0 . 0 5})$

\begin{tabular}{|c|c|c|c|c|c|}
\hline Statement* & $\begin{array}{l}\text { Exp. } \\
\text { Group } \\
\text { M }\end{array}$ & $\begin{array}{l}\text { RC Control } \\
\mathrm{M}(\mathrm{p})\end{array}$ & $\begin{array}{c}6^{\text {th }} \text { Grade } \\
\text { FO Control } \\
\text { M (p) }\end{array}$ & $\begin{array}{c}7^{\text {th }} \text { Grade } \\
\text { FO Control } \\
\text { M (p) }\end{array}$ & $\begin{array}{c}8^{\text {th }} \text { Grade } \\
\text { FO Control } \\
\text { M (p) }\end{array}$ \\
\hline 1. Go outdoors in free time & 3.333 & $3.256(0.3163)$ & 2.635 & 2.506 & 2.617 \\
\hline $\begin{array}{l}\text { 2. Talking to friends and } \\
\text { family }\end{array}$ & 3.350 & $3.551(0.1050)$ & 2.787 & 2.232 & 2.756 \\
\hline $\begin{array}{l}\text { 3. Finding plant and animal } \\
\text { signs }\end{array}$ & 4.457 & 4.154 & 3.773 & 3.595 & 3.707 \\
\hline $\begin{array}{l}\text { 4. Attachment to natural } \\
\text { places }\end{array}$ & 3.825 & $3.795(0.427)$ & 2.787 & 2.398 & 2.621 \\
\hline $\begin{array}{l}\text { 5. Project helps } \\
\text { environment }\end{array}$ & 4.138 & $4.184(0.4761)$ & - & - & - \\
\hline 6. Restore natural areas & 3.864 & $4.000(0.1924)$ & 2.613 & 2.590 & 2.488 \\
\hline $\begin{array}{l}\text { 7. Give } \$ 15 \text { to help } \\
\text { environment }\end{array}$ & 3.925 & $4.192(0.0850)$ & $\begin{array}{c}3.662 \\
(0.1091)\end{array}$ & 3.578 & $\begin{array}{c}3.815 \\
(0.2714)\end{array}$ \\
\hline 8. Spending time in nature & 4.395 & $4.603(0.0683)$ & 3.527 & 3.639 & 3.679 \\
\hline 9. Do something helpful & 4.679 & $4.724(0.3130)$ & 3.959 & 3.651 & 4.050 \\
\hline $\begin{array}{l}\text { 10. Miss natural areas if } \\
\text { move }\end{array}$ & 4.063 & $4.115(0.3711)$ & 2.907 & 3.060 & 2.608 \\
\hline 11. Fun to collect data & 3.750 & $3.821(0.3273)$ & 2.720 & 2.793 & 2.537 \\
\hline 12. Doing something useful & 4.367 & $4.390(0.4274)$ & - & - & 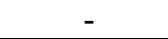 \\
\hline $\begin{array}{l}\text { 13. Show natural area to } \\
\text { friends }\end{array}$ & 3.654 & $3.782(0.2445)$ & 2.707 & 2.506 & 2.325 \\
\hline 14. Collecting data & 3.950 & $4.167(0.0706)$ & 2.892 & 2.963 & 2.802 \\
\hline 15. Learn about ecosystems & 3.802 & $3.935(0.1841)$ & 3.000 & 2.744 & 2.939 \\
\hline 16. Be outdoors & 4.691 & 4.500 & 3.907 & 4.108 & 3.915 \\
\hline 17. Unhealthy landscapes & 4.136 & $3.922(0.0709)$ & 3.067 & 2.571 & 3.061 \\
\hline 18. Aware of my impacts & 4.362 & $4.372(0.4701)$ & 2.967 & 2.763 & 3.282 \\
\hline 19. Get upset & 4.072 & $4.013(0.3665)$ & 2.576 & 2.827 & 3.231 \\
\hline 20. I seek more information & 3.258 & $3.091(0.1785)$ & 2.321 & 2.403 & 2.571 \\
\hline 21. Write letters to officials & 1.696 & $1.513(0.0947)$ & $\begin{array}{c}1.763 \\
(0.3514) \\
\end{array}$ & $\begin{array}{c}1.720 \\
(0.4399) \\
\end{array}$ & $\begin{array}{c}1.618 \\
(0.3111) \\
\end{array}$ \\
\hline 22. Change energy usage & 3.309 & $3.372(0.3759)$ & 2.915 & 2.500 & 2.885 \\
\hline 23. Not go off trail & 3.580 & $4.013(0.0139)$ & 3.373 & 2.883 & 2.947 \\
\hline $\begin{array}{l}\text { 24. Feel at home in natural } \\
\text { areas }\end{array}$ & 3.866 & 3.538 & 2.836 & 2.605 & 2.731 \\
\hline 25. I can identify species & 3.406 & 3.052 & 2.400 & 2.182 & 2.192 \\
\hline 26. Enjoy observing nature & 4.072 & $4.103(0.3580)$ & 3.133 & 3.026 & 2.987 \\
\hline 27. Improve environment & 4.044 & $4.105(0.3580)$ & - & - & - \\
\hline 28. Doing something useful & 4.313 & $4.321(0.4793)$ & 3.276 & 3.208 & 3.584 \\
\hline 29. Talk to others & 3.072 & $3.143(0.3474)$ & 2.746 & 2.299 & 2.520 \\
\hline 30. Park conditions & 3.768 & $3.795(0.4354)$ & 2.542 & 2.805 & 2.870 \\
\hline
\end{tabular}

*Statements have been paraphrased from full statements on survey. Certain statements $(7,12$, and 27) have been removed because they apply to specific projects that FO control groups have not participated in. If $\mathrm{p}<0.05$ and not in bold, then the control group had a statistically significant higher score than the experimental group. 


\section{Overall Stewardship Effects on the Experimental Class}

The overall scores for the stewardship survey (Appendices A.4 and A.5), for Year Two, yield an increase in mean for the experimental class (Quinn), as well as the $\mathrm{RC}$ control class, from the pre- to the post-survey (Table 4.3). When the overall mean scores of the experimental class were compared with the FO control classes, the scores were higher and statistically significant for the experimental group (compared with: $6^{\text {th }}$ grade FO control, $\mathrm{p}<0.0005 ; 7^{\text {th }}$ grade FO control, $\mathrm{p}<0.0005,8^{\text {th }}$ grade FO control, $\left.\mathrm{p}<0.0005\right)$. Quinn also showed an overall increase in mean scores in Year One (Appendices A.1 and A.2), with other teachers exhibiting little change and a decrease in mean for 3 of the 4 classes (Table 4.2).

Table 4.2: Year One Overall Stewardship Survey Results (Appendices A.1 and A.2)

\begin{tabular}{|l|l|l|l|l|}
\hline Teacher & $\begin{array}{l}\text { Grade Level }-\mathrm{n} \\
\left(\text { Total } \mathrm{n}^{*}\right)\end{array}$ & $\begin{array}{l}\mathrm{M}-\text { Pre } \\
(\mathrm{SD})\end{array}$ & $\begin{array}{l}\mathrm{M}-\text { Post } \\
(\mathrm{SD})\end{array}$ & $\begin{array}{l}\text { Change in M } \\
(\mathrm{p})\end{array}$ \\
\hline Cooper & $10-1$ & 3.505 & 3.248 & -0.257 \\
& $11-5(7)$ & $(0.328)$ & $(0.287)$ & $(0.0870)$ \\
& $12-1$ & & & \\
\hline Quinn & $7-26(26)$ & 3.383 & 3.450 & 0.068 \\
& & $(0.484)$ & $(0.364)$ & $(0.2988)$ \\
\hline Marqardt & $9-72(72)$ & 2.429 & 2.300 & -0.129 \\
& & $(0.646)$ & $(0.642)$ & $(0.1218)$ \\
\hline Carnes & $9-15$ & 2.752 & 2.580 & -0.172 \\
& $10-20(41)$ & $(0.522)$ & $(0.631)$ & $(0.0957)$ \\
& $11-3$ & & & \\
\hline
\end{tabular}

*The difference in the total number of students and the breakdown of students per grade comes from the number of students completing the surveys that left the grade level question blank. 
Table 4.3: Year Two Overall Stewardship Survey (Pre/Post) Results (Appendices A.4 and A.5)

\begin{tabular}{|l|l|l|l|l|}
\hline Teacher & $\begin{array}{l}\text { Grade Level - No. } \\
\text { of Post Students } \\
(\text { Total (n) })\end{array}$ & $\begin{array}{l}\text { M - Pre } \\
(\mathrm{SD})\end{array}$ & $\begin{array}{l}\text { M - Post } \\
(\mathrm{SD})\end{array}$ & $\begin{array}{l}\text { Change in M } \\
(\mathrm{p})\end{array}$ \\
\hline $\begin{array}{l}6-31 \\
7-28(81)\end{array}$ & $\begin{array}{l}3.775 \\
(0.491)\end{array}$ & $\begin{array}{l}3.840 \\
(0.522)\end{array}$ & $\begin{array}{l}0.065 \\
(0.1500)\end{array}$ \\
\hline Quinn & $\begin{array}{l}\text { RC Control } \\
7-26\end{array}$ & $\begin{array}{l}3.842 \\
(0.478)\end{array}$ & $\begin{array}{l}3.851 \\
(0.481)\end{array}$ & $\begin{array}{l}0.009 \\
(0.4151)\end{array}$ \\
\hline $\begin{array}{l}\text { 6th Grade FO } \\
\text { Control }\end{array}$ & $6-75(75)$ & $* * *$ & $\begin{array}{l}2.955 \\
(0.774)\end{array}$ & $* * *$ \\
\hline $\begin{array}{l}7 \text { th Grade FO } \\
\text { Control }\end{array}$ & $7-84(84)$ & $* * *$ & $\begin{array}{l}2.821 \\
(0.700)\end{array}$ & $* * *$ \\
\hline $\begin{array}{l}\text { 8th Grade FO } \\
\text { Control }\end{array}$ & $8-84(84)$ & $* * *$ & $\begin{array}{l}2.939 \\
(0.664)\end{array}$ & $* * *$ \\
\hline
\end{tabular}

*The difference in the total number of students and the breakdown of students per grade comes from the number of students completing the survey that left the grade level question blank. ***The individual FO controls did not take the pre-survey.

In Year Two, when taken on a statement-by-statement basis, the stewardship survey results yield a statistically significant $(\mathrm{p}<0.05)$ or close to significant $(\mathrm{p}<0.1)$ increase in mean scores for 5 of the statements for Quinn's class. Because no pre-surveys were completed by the FO controls, no such comparison can be made. While initially I named 5 areas of environmental stewardship, the findings show that 3 general areas of environmental stewardship experienced a change because of the projects completed by the students. The 3 areas, or themes, include: 1. naturalist learning, 2. environmental efficacy, and 3. changes in environmental perception.

\section{Specific Theme 1. Naturalist Learning}

Naturalist learning can be expressed by wanting to learn outdoors. This was exhibited by the experimental students both quantitative and qualitatively. Two statements experienced statistically significant changes in naturalist learning from 
the pre- to the post-stewardship survey (Appendices A.4 and A.5), for the experimental group, including (all quotations are paraphrased unless in quotation marks):

- $\quad$ Statement 3: I don't really like finding signs of animals or learning about the plants, while I am outdoors. (Statement in reverse) $(p=0.0076)$

- Statement 16: I like the chance to be outdoors. $(p=0.0158)$

The experimental group had statistically significant higher scores in naturalist learning than the $\mathrm{RC}$ control group on the same 2 statements:

- $\quad$ Statement 3: I don't really like finding signs of animals or learning about the plants, while I am outdoors. (Statement in reverse) $(p=0.0351)$

- $\quad$ Statement 16: I like the chance to be outdoors. $(p=0.0272)$

These statements were reinforced by the responses from the focus groups

(Appendices B.4, B.5, B.6, and B.7):

- Student: When we first started going outside I didn't realize how connected we all are together.

- $\quad$ Student: Watching salmon eggs hatch, I learned how delicate life really is.

- $\quad$ Student: I drive my parents crazy talking about plants and animals.

- $\quad$ Student: I try to convince my family to go on hikes and walks with me and then I tell them about what I know.

- Student: I have brought family and friends back to the sites where we have visited - hiking at Hoyt Arboretum, Multnomah Falls, Oregon Foodbank, and SOLV.

- $\quad$ Student: I like the forest by my dad's house; we hike there and catch frogs and tadpoles in the pond.

- Parent: We camp.

- Parent: We hike for fun.

- Parent: She gets excited about watching the grey herons.

- $\quad$ Parent: He is identifying holly in the backyard and gets excited about removing it.

- $\quad$ Teacher: Several of the students talk proudly about going back to places we have taken them on site visits (wildlife refuge, Oaks Bottom, Hoyt Arboretum). 
The RC control group experienced a statistically significant change from the pre- to the post-stewardship survey in this area on one statement:

- Statement 8: I think you can get along fine without spending time in nature. (Statement in reverse) $(\mathrm{p}=0.0127)$

This demonstrates the effectiveness of the projects that the students participated in.

\section{Specific Theme 2. Environmental Efficacy}

Environmental efficacy, the interest in affecting change in one's

environment, was also exhibited by the students both quantitative and qualitatively.

Two statements experienced significant or close to statistically significant changes in environmental efficacy from the pre- to the post-stewardship survey (Appendices A.4 and A.5), including:

- Statement 12: I think my work in natural areas is doing something useful. ( $\mathrm{p}=0.0098)$

- Statement 18: I am more aware of my impacts to the natural environment (than before). $(\mathrm{p}=0.0632)$

These statements were reinforced by responses from the focus groups (Appendices

\section{B.4, B.5, B.6, and B.7):}

- Student: After all of the work we do on a site, a difference has really been made.

- Student: I am awed by the amount of work done at the sites and what we did.

- Student: When removing [invasive] blackberry from a roadside and stopping and looking back, it is really impressive.

- Student: I turn off the lights in my house when I go to bed and try to use as much daylight as possible and not watch a lot of TV.

- Student: I take bottles and cans in to be recycled.

- Student: When I ride my bike with my friends I stay on trail and try to convince them to do the same.

- Student: I do litter removal from the ground with my family all the time.

- Parent: My child is turning off the lights all of the time! 
- Parent: When we bought a hybrid car my child did all of the research on fuel efficiency.

- $\quad$ Parent: It is easy to get them to see their results at SOLV.

- $\quad$ Teacher: More than one student has told me they have removed invasive species from their yards and their neighbor's yards based on what we have done at school.

- $\quad$ Teacher: Students are organizing for other students to attend community service projects including ivy pulls and beach cleanups.

The student's passion for their work in the environment was also observed by the graduate students as they worked with the students in the field. Sometimes while explaining the task at hand the students would interrupt with excitement about the work. "Can I just pull any ivy that I see? I just hate ivy," one student said as we were walking to their work and study site. This is an example of environmental efficacy, as well as respect for the environment and improving degraded environments and protecting the environment, a specific area of stewardship.

Parents had great pride in their voices when talking about their children and the way that they are committed to the environmental work they are doing. During the focus group, some mentioned home activities that could have impacted the students' sense of environmental efficacy (Appendix B.6):

- $\quad$ Parent: We have always recycled and composted; we reuse plastic bags, reuse containers, use cloth bags at the grocery store, and buy in bulk to save on packaging [many parents nodded along to these activities].

\section{Specific Theme 3. Changes in Environmental Perception}

Environmental perception, or how the environment is viewed, was exhibited by the students, again, both quantitative and qualitatively. One statement experienced a close to statistically significant change in environmental perception from the pre- to the post-stewardship survey (Appendices A.4 and A.5): 
- Statement 17: I can recognize unhealthy landscapes (like ones with invasive species). $(\mathrm{p}=0.09011)$

This statement was reinforced by response from the focus groups (Appendices B.4, B.5, B.6, and B.7):

- Student: I pull ivy everywhere I see it.

- Student: I'm conscious about trail health; I notice a lot of invasives.

- Student: I pick up litter more.

- Student: I learned how to remove [invasive] blackberry and it has opened my eyes to what is really a problem out there.

- Parent: He identifies reed canary grass and suggests sites that should be SOLV sites next year.

- Parent: My child is often asking, "don't you want to pull the ivy?"

- Teacher: I had one student who for the last three years has continued to remove [invasive] blackberries from his yard.

Students were most excited to share information about their work that they had done (blackberry removal, removing invasive species, cleaning up sites) and about sharing what they learned with others (informing parents to change their energy usage, having the family recycle and start a compost bin, teaching friends about different plants while playing together in the woods).

The experimental group had statistically or close to statistically significant higher scores in changes in environmental perception than the RC control group on 2 statements:

- Statement 17: I can recognize unhealthy landscapes (like ones with invasive species) $\mathrm{p}=0.0709$

- Statement 25: People are often surprised about how many species I can identify in natural areas $(\mathrm{p}=0.0362)$ and close to significantly higher

This demonstrates the effect that the experimental teacher had on his students and their interest and perception of the natural world. 
The results were not as strong in Year One (Table 4.4). When taken on a statement-by-statement basis, the Year One stewardship survey results yield a statistically significant $(p<0.05)$ or close to significant $(p<0.1)$ increase in scores for 2 of the 4 classes on at least one or more statements (Table 4.4).

Table 4.4: Year One Individual Statement Stewardship Survey (Pre/Post) Results (Appendices A.1 and A.2)

\begin{tabular}{|l|l|l|l|l|}
\hline Teacher & Statement & $\begin{array}{l}\text { M - Pre } \\
(\mathrm{SD})\end{array}$ & $\begin{array}{l}\text { M - Post } \\
(\mathrm{SD})\end{array}$ & $\begin{array}{l}\text { Change in M } \\
(\mathrm{p})\end{array}$ \\
\hline Quinn & $\begin{array}{l}\text { 8. I think you can get along fine in } \\
\text { every day life without spending } \\
\text { time in nature. (Statement in } \\
\text { reverse) }\end{array}$ & $\begin{array}{l}3.346 \\
(0.875)\end{array}$ & $4.000(0)$ & $\begin{array}{l}0.654 \\
(\mathrm{p}<0.005)\end{array}$ \\
\hline Quinn & $\begin{array}{l}\text { 12. I would like to help protect } \\
\text { natural areas in other parts of the } \\
\text { country. }\end{array}$ & $\begin{array}{l}3.558 \\
(0.947)\end{array}$ & $3.024(1.047)$ & $\begin{array}{l}0.466 \\
(0.782)\end{array}$ \\
\hline Marquardt & $\begin{array}{l}\text { 4. I feel that natural areas, like } \\
\text { parks, preserves, wildlife refuges, } \\
\text { are important. }\end{array}$ & $\begin{array}{l}2.338 \\
(1.004)\end{array}$ & $3.615(0.560)$ & $\begin{array}{l}0.269 \\
(0.0834)\end{array}$ \\
\hline Marquardt & $\begin{array}{l}\text { 5. I am making a meaningful } \\
\text { contribution to helping the } \\
\text { environment in this project. }\end{array}$ & $\begin{array}{l}1.918 \\
(0.824)\end{array}$ & $2.861(1.004)$ & $\begin{array}{l}0.523 \\
(0.0011)\end{array}$ \\
\hline
\end{tabular}

\section{Past Environmental Experiences}

Results show that students who reported having participated in environmental experiences in the past have a higher stewardship attitude score than those students who had not. Analysis of the pre-stewardship surveys results in statistically significant or close to statistically significant findings for those students that reported having had previous experience in environmental and/or restoration activities (i.e. they reported "yes" to either one or both of the pre-questions on the pre-stewardship survey (Pre-question 1: Have you ever participated in any activities lead by environmental organizations? Pre-question 2: Have you participated in ecological restoration activities before?)), for Year One. For their 
overall pre-stewardship survey scores, 2 of the 4 Year One teachers (Cooper $(\mathrm{p}=0.0469)$ and Carnes $(\mathrm{p}=0.0363))$ had statistically significant higher scores for the students that had participated in activities lead by environmental organizations and/or having participated in ecological restoration activities in the past. Quinn's Year One scores were unable to be analyzed for significance here due to only one student responding "no" to both of the pre-questions; fitting for the class given all of the environmental opportunities the students had. Marquardt's class's scores were higher (average mean for previous experience $=2.452$, average mean no previous experience $=2.251$ ) for those students who had participated, though not statistically significant $(\mathrm{p}=0.1180)$.

Breaking the responses to the pre-questions down further into the 5 stewardship areas, specific areas show higher scores than others (Table 4.5) for a number of the Year One teachers. Cooper's class had statistically significant higher scores in both desire to learn about the environment $(\mathrm{p}=0.0312)$ and improving degraded environments and protecting the environment $(\mathrm{p}=0.0312)$, if the students reported having taken part in restoration and/or environmental activities in the past. Carnes' class had statistically significant $(\mathrm{p}=0.0149)$ higher scores in attachment to place if the students had participated in environmental activities in the past. When comparing previous experience for Carnes' class using post-surveys, the class had significantly higher scores in attachment to place $(\mathrm{p}=0.0020)$, desire to learn about the environment $(\mathrm{p}=0.0083)$, and respect for the environment $(\mathrm{p}=0.0264)$. The post-survey analysis was unable to be run with 
Cooper and Quinn's classes because zero students reported no previous

environmental experience.

Table 4.5: Year One Pre-Stewardship Survey Areas based on Past Experiences with Environmental Activities (Appendix A.1)

\begin{tabular}{|c|c|c|c|c|c|c|c|c|c|c|}
\hline \begin{tabular}{|c|} 
Teacher \\
$\mathrm{n}^{*}$ \\
Prev Exp \\
$\mathrm{n}^{*}$ \\
No Prev \\
Exp
\end{tabular} & $\begin{array}{l}\text { Respect } \\
\text { M } \\
\text { Prev } \\
\text { Exp } \\
\text { No Prev } \\
\text { Exp }\end{array}$ & $\begin{array}{c}\text { (Change } \\
\text { in M) }\end{array}$ & $\begin{array}{c}\text { Learn } \\
M \\
\text { Prev } \\
\text { Exp } \\
\text { No } \\
\text { Prev } \\
\text { Exp }\end{array}$ & $\begin{array}{c}\text { (Change } \\
\text { in M) }\end{array}$ & \begin{tabular}{|l} 
Sharing \\
$M$ \\
Prev \\
Exp \\
No Prev \\
Exp
\end{tabular} & $\begin{array}{c}\text { (Change } \\
\text { in } \mathrm{M})\end{array}$ & \begin{tabular}{|c|} 
Place \\
M \\
Prev \\
Exp \\
No Prev \\
Exp
\end{tabular} & $\begin{array}{c}\text { (Change } \\
\text { in M) }\end{array}$ & \begin{tabular}{|c|} 
Improve \\
$\mathrm{M}$ \\
Prev Exp \\
No Prev \\
Exp
\end{tabular} & \begin{tabular}{|c|} 
(Change \\
in M)
\end{tabular} \\
\hline $\begin{array}{c}\text { Cooper } \\
5 \\
2 \\
\end{array}$ & $\begin{array}{l}3.900 \\
3.500\end{array}$ & \begin{tabular}{|l|}
$(0.400)$ \\
$\mathbf{0 . 0 3 1 2}$
\end{tabular} & $\begin{array}{l}4.000 \\
2.500\end{array}$ & & $\begin{array}{l}3.100 \\
3.250 \\
\end{array}$ & & $\begin{array}{l}3.550 \\
3.250 \\
\end{array}$ & & $\begin{array}{l}3.600 \\
3.400\end{array}$ & \begin{tabular}{|l|}
$(0.200)$ \\
$\mathbf{0 . 0 3 1 2}$
\end{tabular} \\
\hline \begin{tabular}{|ll} 
Marquar \\
dt & \\
& 41 \\
& 31 \\
\end{tabular} & $\begin{array}{l}2.293 \\
2.048\end{array}$ & \begin{tabular}{|c|}
$(0.245)$ \\
0.1370
\end{tabular} & $\begin{array}{l}2.427 \\
2.403\end{array}$ & $\begin{array}{c}(0.024) \\
0.4544\end{array}$ & $\begin{array}{l}2.207 \\
2.016\end{array}$ & $\begin{array}{c}(0.191) \\
0.1592\end{array}$ & $\begin{array}{l}2.848 \\
2.605\end{array}$ & $\begin{array}{c}(0.243) \\
0.0774\end{array}$ & $\begin{array}{l}2.488 \\
2.184\end{array}$ & \begin{tabular}{|l|}
$(0.304)$ \\
0.1370
\end{tabular} \\
\hline $\begin{array}{c}\text { arnes } \\
18 \\
15\end{array}$ & $\begin{array}{l}3.028 \\
2.833\end{array}$ & 0.2228 & $\begin{array}{l}2.639 \\
2.417\end{array}$ & $\begin{array}{l}(0.222) \\
0.1633\end{array}$ & $\begin{array}{l}2.611 \\
2.583\end{array}$ & $\begin{array}{l}(0.028) \\
0.4501\end{array}$ & $\begin{array}{l}3.104 \\
2.583\end{array}$ & $\begin{array}{l}(0.521) \\
\mathbf{0 . 0 1 4 9}\end{array}$ & $\begin{array}{l}2.789 \\
2.490\end{array}$ & \begin{tabular}{|l|}
$(0.299)$ \\
0.2228
\end{tabular} \\
\hline
\end{tabular}

A response of "yes" to either pre-question 1 and/or pre-question 2 results in Previous Experience; a response of "no" to both pre-question 1 and pre-question 2 results in No Previous Experience. *n values may not be equal to initial $\mathrm{n}$ values given in Table 4.2 due to missing responses to both prequestion 1 and 2.

In Year Two, when the surveys were analyzed in regards to previous environmental restoration work (answering "yes" to the Pre-question: Have you ever helped to restore or conduct research in a natural area before this class?), the results are again encouraging (Table 4.6). In the $7^{\text {th }}$ grade FO control group, across all areas of environmental stewardship, the students who had previous environmental experience had statistically significant higher scores than their classmates who did not. In the $8^{\text {th }}$ grade FO control group, in 3 areas of environmental stewardship (interest in sharing environmental knowledge with others $(\mathrm{p}<0.005)$, attachment to place $(\mathrm{p}=0.0118)$, and improving degraded environments and protecting the environment $(\mathrm{p}<0.005))$, the students who had 
previous experience had statistically significant higher scores than their classmates who did not. The $6^{\text {th }}$ grade FO control group was close to significant in some stewardship areas but their $\mathrm{n}$ for no previous experience was very low. The test on the $\mathrm{RC}$ control was unable to be run because there were zero responses of having no previous experience reported by the students. The experiential group, also with low numbers (4) for no previous experience, did not have any significantly higher scores in any of the areas those that reported having prior environmental restoration experience. 
Table 4.6: Year Two Post-Stewardship Survey Areas based on Past Experiences with Environmental Activities for Experimental and FO Control Groups (Appendix A.5)

\begin{tabular}{|c|c|c|c|c|c|c|c|c|c|c|}
\hline $\begin{array}{c}\text { Teacher } \\
\mathrm{n}^{*} \\
\text { Prev } \\
\text { Exp } \\
\mathrm{n}^{*} \\
\text { No } \\
\text { Prev } \\
\text { Exp } \\
\end{array}$ & \begin{tabular}{|c|} 
Respect \\
$\mathrm{M}$ \\
Prev \\
Exp \\
No \\
Prev \\
Exp
\end{tabular} & $\begin{array}{c}\text { (Change } \\
\text { in M) } \\
\text { p }\end{array}$ & $\begin{array}{c}\text { Learn } \\
\mathrm{M} \\
\text { Prev } \\
\text { Exp } \\
\text { No } \\
\text { Prev } \\
\text { Exp }\end{array}$ & $\begin{array}{c}\text { (Change } \\
\text { in } \mathrm{M}) \\
\mathrm{p}\end{array}$ & \begin{tabular}{|c} 
Sharing \\
M \\
Prev \\
Exp \\
No \\
Prev \\
Exp
\end{tabular} & $\begin{array}{c}\text { (Change } \\
\text { in } \mathrm{M}) \\
\mathrm{p}\end{array}$ & \begin{tabular}{|c} 
Place \\
M \\
Prev \\
Exp \\
No \\
Prev \\
Exp
\end{tabular} & $\begin{array}{c}\text { (Change } \\
\text { in } \mathrm{M}) \\
\mathrm{p}\end{array}$ & $\begin{array}{c}\text { Improve } \\
M \\
\text { Prev } \\
\text { Exp } \\
\text { No Prev } \\
\text { Exp }\end{array}$ & $\begin{array}{c}\text { (Change } \\
\text { in } \mathrm{M} \text { ) } \\
\mathrm{p}\end{array}$ \\
\hline $\begin{array}{c}\text { Quinn } \\
77 \\
4 \\
\end{array}$ & $\begin{array}{l}3.950 \\
3.875 \\
\end{array}$ & \begin{tabular}{|l|}
$(0.075)$ \\
0.4194
\end{tabular} & $\begin{array}{l}3.960 \\
3.607 \\
\end{array}$ & \begin{tabular}{|l|}
$(0.353)$ \\
0.1514
\end{tabular} & $\begin{array}{l}3.419 \\
3.188 \\
\end{array}$ & \begin{tabular}{|l|}
$(0.231)$ \\
0.2744 \\
\end{tabular} & $\begin{array}{l}4.052 \\
3.625 \\
\end{array}$ & $\begin{array}{c}(0.427) \\
0.0790\end{array}$ & $\begin{array}{l}3.873 \\
3.778 \\
\end{array}$ & $\begin{array}{l}(0.095) \\
0.3729\end{array}$ \\
\hline $\begin{array}{c}6^{\text {th }} \\
\text { Grade } \\
\text { FO } \\
\text { Control } \\
5 \\
63 \\
\end{array}$ & $\begin{array}{l}2.950 \\
2.820 \\
\end{array}$ & \begin{tabular}{|l|}
$(0.130)$ \\
0.4257
\end{tabular} & $\begin{array}{l}3.186 \\
2.956 \\
\end{array}$ & \begin{tabular}{|l|}
$(0.230)$ \\
0.3052 \\
\end{tabular} & $\begin{array}{l}3.100 \\
3.566 \\
\end{array}$ & $\begin{array}{c}(-0.466) \\
0.0950\end{array}$ & $\begin{array}{l}3.533 \\
3.000 \\
\end{array}$ & $\begin{array}{l}(0.533) \\
0.0892\end{array}$ & $\begin{array}{l}3.480 \\
2.934 \\
\end{array}$ & $\begin{array}{l}(0.546) \\
0.0750\end{array}$ \\
\hline $\begin{array}{c}7^{\text {th }} \\
\text { Grade } \\
\text { FO } \\
\text { Control } \\
40 \\
33\end{array}$ & $\begin{array}{l}3.238 \\
2.401\end{array}$ & $\begin{array}{l}(0.837) \\
<\mathbf{0 . 0 0 5}\end{array}$ & $\begin{array}{l}3.269 \\
2.501\end{array}$ & $\begin{array}{l}(0.768) \\
<\mathbf{0 . 0 0 5}\end{array}$ & $\begin{array}{l}2.606 \\
2.014\end{array}$ & \begin{tabular}{|l|}
$(0.592)$ \\
$<\mathbf{0 . 0 0 5}$
\end{tabular} & \begin{tabular}{|l|}
3.413 \\
2.706
\end{tabular} & $\begin{array}{l}(0.707) \\
<\mathbf{0 . 0 0 5}\end{array}$ & $\begin{array}{l}3.149 \\
2.432\end{array}$ & $\begin{array}{l}(0.717) \\
<\mathbf{0 . 0 0 5}\end{array}$ \\
\hline $\begin{array}{c}8^{\text {th }} \\
\text { Grade } \\
\text { FO } \\
\text { Control } \\
18 \\
52 \\
\end{array}$ & $\begin{array}{l}3.367 \\
3.031 \\
\end{array}$ & \begin{tabular}{|l|}
$(0.336)$ \\
0.1170
\end{tabular} & $\begin{array}{l}3.136 \\
2.948 \\
\end{array}$ & $\begin{array}{c}(0.188) \\
0.2134\end{array}$ & $\begin{array}{l}2.792 \\
2.272 \\
\end{array}$ & \begin{tabular}{|l|}
$(0.520)$ \\
$<\mathbf{0 . 0 0 5}$ \\
\end{tabular} & \begin{tabular}{|l}
3.434 \\
2.931 \\
\end{tabular} & $\begin{array}{l}(0.503) \\
\mathbf{0 . 0 1 1 8}\end{array}$ & $\begin{array}{l}3.338 \\
2.795 \\
\end{array}$ & $\begin{array}{l}(0.543) \\
<\mathbf{0 . 0 0 5}\end{array}$ \\
\hline
\end{tabular}

A response of "yes" to the pre-question results in Previous Experience; a response of "no" to the pre-question and results in No Previous Experience. "n values may not be equal to initial $\mathrm{n}$ values given in Table 4.3 due to a missing response to the pre-question.

\section{Gender}

The results show that females have a greater stewardship attitude score than males of the same grade. Breaking the Year One stewardship survey results into females and males resulted in some statistically significant findings (Tables 4.7, 4.8, and 4.9). Quinn's Year One female students had significantly higher scores than their male counterparts on the pre-survey in the area of respect for the environment $(\mathrm{p}=0.0377)$, as well as on the post-survey in this area $(\mathrm{p}=0.0473)$ 
(Table 4.7). The females showed higher mean scores on the post-survey in all areas and on the pre-survey in all but one area of environmental stewardship (desire to learn about the environment). The post-survey also showed statistically higher scores for the females in the area of attachment to place $(p=0.0269)$ and a significantly higher mean score for females on the pre- compared with the postsurvey in this area $(\mathrm{p}=0.0158)$. Because of the low $\mathrm{n}$ for Cooper's class, and having only 1 male student complete the pre-survey, the t-test for significance was unable to be run for that group.

Table 4.7: Year One Quinn's Class Pre/Post Stewardship Survey Areas based on Gender (Appendices A.1 and A.2)

\begin{tabular}{|c|c|c|c|c|c|c|c|c|c|c|}
\hline $\begin{array}{c}\text { Survey } \\
\mathrm{n}^{*} \mathrm{~F} \\
\mathrm{n}^{*} \mathrm{M}\end{array}$ & $\begin{array}{c}\text { Respect } \\
\mathrm{M} \\
\text { Female } \\
\text { Male }\end{array}$ & $\mathrm{p}$ & $\begin{array}{c}\text { Learn } \\
\text { M } \\
\text { Female } \\
\text { Male }\end{array}$ & $\mathrm{P}$ & $\begin{array}{c}\text { Sharing } \\
\mathrm{M} \\
\text { Female } \\
\text { Male }\end{array}$ & $\mathrm{p}$ & \begin{tabular}{|c} 
Place \\
M \\
Female \\
Male
\end{tabular} & $\mathrm{P}$ & $\begin{array}{c}\text { Improve } \\
\text { M } \\
\text { Female } \\
\text { Male }\end{array}$ & $\mathrm{p}$ \\
\hline $\begin{array}{c}\text { Pre: } 10 \\
14\end{array}$ & & $\begin{array}{c}\mathbf{0 . 0 3 7 7} \\
* * \mathbf{F}\end{array}$ & $\begin{array}{l}3.350 \\
3.571\end{array}$ & 0.1988 & $\begin{array}{l}3.200 \\
3.143\end{array}$ & 0.3568 & $\begin{array}{l}3.650 \\
3.339\end{array}$ & 0.1057 & $\begin{array}{l}3.620 \\
3.257\end{array}$ & 0.0655 \\
\hline $\begin{array}{c}\text { Post: } 9 \\
18\end{array}$ & $\begin{array}{l}3.667 \\
3.250\end{array}$ & $\begin{array}{c}\mathbf{0 . 0 4 7 3} \\
* * \mathbf{F}\end{array}$ & $\begin{array}{l}3.556 \\
3.472\end{array}$ & 0.3253 & $\begin{array}{l}3.167 \\
2.833\end{array}$ & 0.1149 & $\begin{array}{l}3.778 \\
3.486\end{array}$ & $\begin{array}{c}0.0269 \\
* * \mathbf{F}\end{array}$ & $\begin{array}{l}3.667 \\
3.469\end{array}$ & 0.1564 \\
\hline $\begin{array}{c}\text { Post- } \\
\text { Pre } \\
\text { Change } \\
\text { Female } \\
\text { (Male) }\end{array}$ & $\begin{array}{c}0.017 \\
(0)\end{array}$ & $\begin{array}{l}0.4631 \\
0.5000\end{array}$ & $\begin{array}{c}0.206 \\
(-0.099)\end{array}$ & $\begin{array}{l}0.2261 \\
0.2929\end{array}$ & $\begin{array}{c}-0.033 \\
(-0.310)\end{array}$ & $\begin{array}{l}0.4600 \\
0.0829\end{array}$ & $\begin{array}{c}0.128 \\
(0.147)\end{array}$ & $\begin{array}{c}\mathbf{0 . 0 1 5 8} \\
0.2378 \\
* * \mathbf{F}\end{array}$ & $\begin{array}{c}0.047 \\
(0.212)\end{array}$ & $\begin{array}{l}0.4094 \\
0.1140\end{array}$ \\
\hline
\end{tabular}

*n values may not be equal to initial $\mathrm{n}$ values given in Table 4.2 due to no response to gender question. ${ }^{* * \mathrm{~F}}=$ statistically significant higher scores for females as compared to males in their class or a statically significant increase in scores from pre- to post-survey for females.

Marquardt's class had statistically significant higher scores for the females in all stewardship areas of the post-survey (Table 4.8). On the pre-survey, all of the stewardship area mean scores for the females were higher than the males, though only 2 were statistically significant (interest in sharing environmental knowledge with others $(\mathrm{p}=0.0407)$ and improving degraded environments and protecting the environment $(\mathrm{p}=0.0133)$ ). This same group of females had a significant increase in 
their scores from the pre- to the post-survey in the area of respect for the

environment $(\mathrm{p}=0.0051)$.

Table 4.8: Year One Marquardt's Class Pre/Post Stewardship Survey Areas based on Gender (Appendices A.1 and A.2)

\begin{tabular}{|c|c|c|c|c|c|c|c|c|c|c|}
\hline $\begin{array}{c}\text { Survey } \\
\mathrm{n}^{*} \mathrm{~F} \\
\mathrm{n}^{*} \mathrm{M}\end{array}$ & \begin{tabular}{|c|} 
Respect \\
$\mathrm{M}$ \\
Female \\
Male
\end{tabular} & $\mathrm{p}$ & \begin{tabular}{|c} 
Learn \\
M \\
Female \\
Male
\end{tabular} & $\mathrm{P}$ & \begin{tabular}{|c} 
Sharing \\
M \\
Female \\
Male
\end{tabular} & $\mathrm{p}$ & \begin{tabular}{|c} 
Place \\
M \\
Female \\
Male
\end{tabular} & $\mathrm{P}$ & \begin{tabular}{|c|} 
Improve \\
$\mathrm{M}$ \\
Female \\
Male
\end{tabular} & $\mathrm{p}$ \\
\hline $\begin{array}{r}\text { re: } 42 \\
31 \\
\end{array}$ & $\begin{array}{l}2.274 \\
2.081 \\
\end{array}$ & 0.19 & $\begin{array}{l}2.476 \\
2.371 \\
\end{array}$ & 0.3042 & $\begin{array}{l}2.286 \\
1.952 \\
\end{array}$ & $* * \mathbf{F}$ & $\begin{array}{l}2.827 \\
2.629 \\
\end{array}$ & 02 & $\begin{array}{l}2.524 \\
2.145 \\
\end{array}$ & $\begin{array}{c}0.0133 \\
* * F\end{array}$ \\
\hline 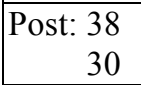 & $\begin{array}{l}2.671 \\
2.133\end{array}$ & $\begin{array}{c}0.0051 \\
* * \mathbf{F}\end{array}$ & $\begin{array}{l}2.500 \\
2.100\end{array}$ & $\begin{array}{c}0.0429 \\
* * \mathbf{F}\end{array}$ & $\begin{array}{l}.053 \\
1.633\end{array}$ & $\begin{array}{c}0.0124 \\
* * F\end{array}$ & $\begin{array}{l}2.697 \\
2.289\end{array}$ & $\begin{array}{c}0.0075 \\
* * F\end{array}$ & $\begin{array}{l}2.332 \\
1.933\end{array}$ & $\begin{array}{c}0.0108 \\
* * F\end{array}$ \\
\hline $\begin{array}{l}\text { Ost-Pre } \\
\text { Change } \\
\text { Female }\end{array}$ & $\begin{array}{c}0.397 \\
(0.052)\end{array}$ & $\begin{array}{c}\mathbf{0 . 0 2 2 1} \\
0.4102 \\
* * \mathrm{~F}\end{array}$ & $\begin{array}{c}0.024 \\
(-0.271)\end{array}$ & $\begin{array}{l}0.4542 \\
0.1145\end{array}$ & $\begin{array}{c}-0.233 \\
(-0.319)\end{array}$ & $\begin{array}{l}0.0811 \\
0.0674\end{array}$ & $\begin{array}{c}-0.130 \\
(-0.340)\end{array}$ & $\begin{array}{l}0.1995 \\
0.0305\end{array}$ & $\begin{array}{c}-0.192 \\
(-0.212)\end{array}$ & $\begin{array}{l}0.1008 \\
0.1463\end{array}$ \\
\hline
\end{tabular}

*n values may not be equal to initial $\mathrm{n}$ values given in Table 4.2 due to no response to gender question. ${ }^{*} \mathrm{~F}=$ statistically significant higher scores for females as compared to males in their class or a statically significant increase in scores from pre- to post-survey for females.

Carnes' females had significantly higher scores than the males in their class

on the pre-survey in all of the stewardship areas except sharing environmental

knowledge (Table 4.9). On the post-survey, the females only had significantly

higher scores than the males in the area of improving degraded environments and

protecting the environment $(\mathrm{p}=0.0441)$. There was no significant increase in mean

scores for males or females from the pre- to the post-survey, for this class. 
Table 4.9: Year One Carnes' Class Pre/Post Stewardship Survey Areas based on Gender (Appendices A.1 and A.2)

\begin{tabular}{|c|c|c|c|c|c|c|c|c|c|c|}
\hline $\begin{array}{c}\text { Survey } \\
\mathrm{n} * \mathrm{~F}\end{array}$ & $\begin{array}{c}\text { Respect } \\
\mathrm{M}\end{array}$ & $\mathrm{p}$ & $\begin{array}{c}\text { Learn } \\
\mathrm{M}\end{array}$ & $\mathrm{P}$ & $\begin{array}{c}\text { Sharing } \\
\mathrm{M}\end{array}$ & $\mathrm{p}$ & $\begin{array}{c}\text { Place } \\
\mathrm{M}\end{array}$ & $\mathrm{P}$ & $\begin{array}{c}\text { Improve } \\
\mathrm{M}\end{array}$ & $\mathrm{p}$ \\
$\mathrm{n} * \mathrm{M}$ & $\begin{array}{c}\text { Female } \\
\text { Male }\end{array}$ & & $\begin{array}{c}\text { Female } \\
\text { Male }\end{array}$ & & $\begin{array}{c}\text { Female } \\
\text { Male }\end{array}$ & & $\begin{array}{c}\text { Female } \\
\text { Male }\end{array}$ & & $\begin{array}{c}\text { Female } \\
\text { Male }\end{array}$ & \\
\hline Pre: 25 & 3.160 & $\mathbf{0 . 0 0 1 7}$ & 2.690 & 0.1720 & 2.790 & $\mathbf{0 . 0 1 1 2}$ & 3.040 & $\mathbf{0 . 0 2 2 5}$ & 2.886 & $\mathbf{0 . 0 0 6 8}$ \\
11 & 2.455 & $* * \mathbf{F}$ & 2.455 & & 2.273 & $* * \mathbf{F}$ & 2.557 & $* * \mathbf{F}$ & 2.273 & $* * \mathbf{F}$ \\
\hline Post: 23 & 2.826 & 0.1904 & 2.826 & 0.1270 & 2.304 & 0.3777 & 2.913 & 0.2910 & 2.696 & $\mathbf{0 . 0 4 4 1}$ \\
13 & 2.577 & & 2.500 & & 2.385 & & 2.788 & & 2.215 & $* * \mathbf{F}$ \\
\hline $\begin{array}{c}\text { Post- } \\
\text { Pre }\end{array}$ & & & & & & & & & & \\
Change & & & & & & & & & & \\
Female & -0.334 & 0.0514 & 0.136 & 0.2735 & -0.486 & 0.0031 & -0.127 & 0.2328 & -0.190 & 0.1702 \\
(Male) & $(0.122)$ & 0.2325 & $(0.045)$ & 0.4361 & $(0.112)$ & 0.3710 & $(0.231)$ & 0.2239 & $(-0.058)$ & 0.4313 \\
\hline
\end{tabular}

*n values may not be equal to initial $\mathrm{n}$ values given in Table 4.2 due to no response to gender question. $* * \mathrm{~F}=$ statistically significant higher scores for females as compared to males in their class or a statically significant increase in scores from pre- to post-survey for females.

Analyzing the post-stewardship survey results for gender in Year Two reveals that out of the 5 survey groups, 3 had statistically higher scores by the female students in the area of respect for the environment than their male counterparts (Table 4.10). The experimental group was the only group to have any area of environmental stewardship receive higher scores by the male students (improving degraded environments and protecting the environment, $\mathrm{p}=0.0173$ ). The $8^{\text {th }}$ grade FO control group had statistically higher scores by the female respondents in all areas of environmental stewardship except interest in sharing environmental knowledge with others $(p=0.0654)$, though it was close to significant. 
Table 4.10: Year Two Post-Survey Stewardship Areas based on Gender (Appendix A.5)

\begin{tabular}{|c|c|c|c|c|c|c|c|c|c|c|}
\hline $\begin{array}{c}\text { Teacher } \\
\mathrm{n} * \mathrm{~F} \\
\mathrm{n} * \mathrm{M}\end{array}$ & $\begin{array}{c}\text { Respect } \\
\text { M } \\
\text { Female } \\
\text { Male } \\
\end{array}$ & $\mathrm{p}$ & $\begin{array}{c}\text { Learn } \\
\text { M } \\
\text { Female } \\
\text { Male }\end{array}$ & $\mathrm{p}$ & $\begin{array}{c}\text { Sharing } \\
\text { M } \\
\text { Female } \\
\text { Male }\end{array}$ & $\mathrm{p}$ & $\begin{array}{c}\text { Place } \\
\text { M } \\
\text { Female } \\
\text { Male }\end{array}$ & $\mathrm{p}$ & $\begin{array}{c}\text { Improve } \\
\text { M } \\
\text { Female } \\
\text { Male }\end{array}$ & $\mathrm{p}$ \\
\hline $\begin{array}{c}\text { Quinn } \\
32 \\
49\end{array}$ & $\begin{array}{l}4.232 \\
3.750\end{array}$ & $\begin{array}{c}0.0023 \\
* * \mathbf{F}\end{array}$ & $\begin{array}{l}3.889 \\
3.977\end{array}$ & 0.2813 & $\begin{array}{l}3.328 \\
3.459\end{array}$ & 0.2216 & $\begin{array}{l}4.059 \\
4.012\end{array}$ & 0.361 & $\begin{array}{l}4.032 \\
3.761\end{array}$ & $\begin{array}{c}\mathbf{0 . 0 1 7 3} \\
* * \mathbf{M}\end{array}$ \\
\hline $\begin{array}{c}\mathrm{RC} \\
\text { Control } \\
34 \\
44\end{array}$ & $\begin{array}{l}4.162 \\
3.960\end{array}$ & 0.0884 & $\begin{array}{l}3.949 \\
3.843\end{array}$ & 0.2066 & $\begin{array}{l}3.471 \\
3.326\end{array}$ & 0.2138 & $\begin{array}{l}4.098 \\
3.867\end{array}$ & 0.052 & $\begin{array}{l}3.807 \\
3.326\end{array}$ & 0.2175 \\
\hline $\begin{array}{c}6^{\text {th }} \\
\text { Grade } \\
\text { FO } \\
\text { Control } \\
39 \\
35\end{array}$ & $\begin{array}{l}3.115 \\
2.606\end{array}$ & $\begin{array}{c}\mathbf{0 . 0 1 9 5} \\
* * \mathbf{F}\end{array}$ & $\begin{array}{l}3.209 \\
2.813\end{array}$ & $\begin{array}{c}\mathbf{0 . 0 3 7 4} \\
* * \mathbf{F}\end{array}$ & $\begin{array}{l}2.741 \\
2.542\end{array}$ & 0.1656 & $\begin{array}{l}3.181 \\
3.021\end{array}$ & 0.215 & $\begin{array}{l}3.073 \\
2.870\end{array}$ & 0.1396 \\
\hline $\begin{array}{c}7^{\text {th }} \\
\text { Grade } \\
\text { FO } \\
\text { Control } \\
34 \\
50\end{array}$ & $\begin{array}{l}2.855 \\
2.802\end{array}$ & 0.4108 & $\begin{array}{l}3.006 \\
2.811\end{array}$ & 0.1453 & $\begin{array}{l}2.353 \\
2.309\end{array}$ & 0.4086 & $\begin{array}{l}3.113 \\
3.031\end{array}$ & 0.308 & $\begin{array}{l}2.867 \\
2.778\end{array}$ & 0.2964 \\
\hline $\begin{array}{c}8^{\text {th }} \\
\text { Grade } \\
\text { FO } \\
\text { Control } \\
45 \\
33\end{array}$ & $\begin{array}{l}2.488 \\
2.533\end{array}$ & $\begin{array}{c}<0.005 \\
* * \mathbf{F}\end{array}$ & $\begin{array}{l}3.151 \\
2.743\end{array}$ & $\begin{array}{c}0.0155 \\
* * \mathbf{F}\end{array}$ & $\begin{array}{l}2.538 \\
2.285\end{array}$ & 0.0654 & $\begin{array}{l}3.221 \\
2.806\end{array}$ & $\begin{array}{c}\mathbf{0 . 0 1 1} \\
* * \mathbf{F}\end{array}$ & $\begin{array}{l}3.146 \\
2.633\end{array}$ & $\begin{array}{c}<0.005 \\
* * \mathbf{F}\end{array}$ \\
\hline
\end{tabular}

*n values may not be equal to initial $\mathrm{n}$ values given in Table 4.3 due to missing responses to the gender question. ${ }^{* *} \mathrm{~F}=$ statistically significant higher scores for females as compared to males in their class. ${ }^{* *} \mathrm{M}=$ statistically significant higher scores for males as compared to females in their class.

\section{Grade}

Analyzing the post-surveys for significance in grade reveals that when the experimental group is divided into its component grades $\left(6^{\text {th }}, 7^{\text {th }}\right.$, and $\left.8^{\text {th }}\right)$, each grade has a statistically significant higher score than the comparable FO control grades in all of the areas of environmental stewardship (Table 4.11). The grade-bygrade comparison was not done between the experimental and $\mathrm{RC}$ control because of already exhibited similar scores between these two groups (Table 4.3). 
Table 4.11: Year Two Post-Survey Stewardship Areas based on Grade for Experimental and FO Control Groups (Appendix A.5)

\begin{tabular}{|c|c|c|c|c|c|c|c|c|c|c|}
\hline Teacher: $\mathrm{n}^{*}$ & \begin{tabular}{|c|} 
Respect \\
$\mathrm{M}$
\end{tabular} & $\mathrm{p}$ & $\begin{array}{c}\text { Learn } \\
\mathrm{M}\end{array}$ & $\mathrm{p}$ & $\begin{array}{c}\text { Sharing } \\
\mathrm{M}\end{array}$ & $\mathrm{p}$ & $\begin{array}{c}\text { Place } \\
\text { M }\end{array}$ & $\mathrm{p}$ & \begin{tabular}{|c|} 
Improve \\
$\mathrm{M}$
\end{tabular} & $\mathrm{p}$ \\
\hline $6^{\text {th }}$ Grade & & & & & & & & & & \\
\hline Quinn: 31 & 3.850 & $<0.005 \mid$ & & $<0.005$ & & $<0.005$ & 4.066 & $<0.005$ & 3.794 & $|<\mathbf{0 . 0 0 5}|$ \\
\hline$\frac{\text { FO Control: } 75}{7^{\text {th }} \text { Grade }}$ & 873 & & 3.019 & & & & 3.104 & & 2.976 & \\
\hline $\begin{array}{l}\text { Quinn: } 28 \\
\text { FO Control: } 84\end{array}$ & $\begin{array}{l}3.885 \\
2.824\end{array}$ & $<0.005$ & $\begin{array}{l}3.709 \\
2.890\end{array}$ & $<0.005$ & $\begin{array}{l}3.125 \\
2.327\end{array}$ & $<0.005$ & $\begin{array}{l}3.879 \\
3.064\end{array}$ & $<0.005$ & $\begin{array}{l}3.709 \\
2.814\end{array}$ & $<0.005$ \\
\hline $8^{\text {th }}$ Grade & & & & & & & & & & \\
\hline $\begin{array}{l}\text { Quinn: } 22 \\
\text { FO Control: } 84\end{array}$ & $\begin{array}{l}4.138 \\
3.087\end{array}$ & $<0.005$ & $\begin{array}{l}4.278 \\
2.949\end{array}$ & $<0.005$ & $\begin{array}{l}3.795 \\
2.436\end{array}$ & $<0.005$ & $\begin{array}{l}4.174 \\
3.028\end{array}$ & $<0.005$ & $\begin{array}{l}4.176 \\
2.913\end{array}$ & $<0.005$ \\
\hline
\end{tabular}

$*_{n}$ values may not be equal to initial $\mathrm{n}$ values given in Table 4.3 due to missing responses to the gender question.

\section{Science Interest Survey Results}

Overall, the science interest survey results are not strongly significant. The data can be used to supplement the stewardship data.

\section{Year One: Science Interest Survey Results}

The overall scores for the science interest survey (Appendix A.3) yield a decrease in mean for 3 of the 4 classes from the pre- to the post-survey (Table 4.12). When taken on a statement-by-statement basis, the results yield a statistically significant $(\mathrm{p}<0.05)$ or close to significant $(\mathrm{p}<0.1)$ increase in score for 1 of the 4 classes (Table 4.13). Quinn's class had 1 statement that had a statistically significant increase $(\mathrm{p}=0.0073)$ and 2 statements that had a close to significant increase $(\mathrm{p}=0.0823$ and $\mathrm{p}=0.0811)$ in mean score. 
Table 4.12: Year One Overall Science Interest Survey Results (Appendix A.3)

\begin{tabular}{|l|l|l|l|l|}
\hline Teacher & $\begin{array}{l}\text { Grade Level }-\mathrm{n} \\
(\text { Total } \mathrm{n})\end{array}$ & $\begin{array}{l}\mathrm{M}-\text { Pre } \\
(\mathrm{SD})\end{array}$ & $\begin{array}{l}\mathrm{M}-\text { Post } \\
(\mathrm{SD})\end{array}$ & $\begin{array}{l}\text { Change in M } \\
(\mathrm{p})\end{array}$ \\
\hline Cooper & $10-1$ & 2.473 & 2.289 & -0.184 \\
& $(1-4(6)$ & $(0.261)$ & $(0.274)$ & $(0.1397)$ \\
\hline Quinn & $7-26(26)$ & 2.404 & 2.482 & 0.0778 \\
& & $(0.230)$ & $(0.220)$ & $\mathbf{( 0 . 0 1 1 1 )}$ \\
\hline Marqardt & $9-72(72)$ & 2.121 & 1.935 & -0.186 \\
& & $(0.289)$ & $(0.341)$ & $(0.0002)$ \\
\hline Carnes & $9-17$ & 2.022 & 1.945 & -0.077 \\
& $10-19$ & $(0.386)$ & $(0.277)$ & $(0.1560)$ \\
& $11-2(40)$ & & & \\
& $12-1$ & & & \\
\hline
\end{tabular}

*The difference in the total number of students and the breakdown of students per grade comes from the number of students completing the surveys that left the grade level question blank.

Table 4.13: Year One Individual Statement Science Interest Survey (Pre/Post) Results (Appendix A.3)

\begin{tabular}{|c|c|c|c|c|}
\hline Teacher & Statement & $\begin{array}{l}\text { M-Pre } \\
(\mathrm{SD})\end{array}$ & $\begin{array}{l}\mathrm{M}-\text { Post } \\
(\mathrm{SD})\end{array}$ & $\begin{array}{l}\text { Change in M } \\
\text { (p) }\end{array}$ \\
\hline Quinn & $\begin{array}{l}\text { 8. I think you can get along } \\
\text { perfectly well in everyday } \\
\text { life without science. } \\
\text { (Statement in reverse) }\end{array}$ & $\begin{array}{l}2.400 \\
(0.638)\end{array}$ & $\begin{array}{l}2.815 \\
(0.388)\end{array}$ & $\begin{array}{l}0.375 \\
(0.0073)\end{array}$ \\
\hline Quinn & $\begin{array}{l}10 . \text { I would rather be given } \\
\text { the right answer to a science } \\
\text { problem than to work it out } \\
\text { myself. (Statement in } \\
\text { reverse) }\end{array}$ & $\begin{array}{l}2.231 \\
(0.697)\end{array}$ & $\begin{array}{l}2.4815 \\
(0.569)\end{array}$ & $\begin{array}{l}0.251 \\
(0.0823)\end{array}$ \\
\hline Quinn & $\begin{array}{l}\text { 12. I am more curious about } \\
\text { the plants, animals, earth } \\
\text { and universe where I live } \\
\text { because of my science } \\
\text { lessons. }\end{array}$ & $\begin{array}{l}2.346 \\
(0.676)\end{array}$ & $\begin{array}{l}2.593 \\
(0.562)\end{array}$ & $\begin{array}{l}0.246 \\
(0.0811)\end{array}$ \\
\hline
\end{tabular}

\section{Year Two: Science Interest Survey Results}

Analysis of the science interest survey (Appendix A.6) scores yield an increase in mean scores from the pre- to the post-survey for both the experimental and RC control group (Table 4.15). The FO control groups did not take the presurvey so there is no change in mean to report. When taken on a statement-bystatement basis, the results yield a statistically significant $(\mathrm{p}<0.05)$ or close to significant $(\mathrm{p}<0.1)$ increase in mean score for both the experimental and RC control 
group on several statements (Table 4.15). The experimental group approached a significant increase in mean score on statements 6 and 11 (I have become more aware of the environment because of my science lessons, $\mathrm{p}=0.0879$; I am more curious about plants, animals, earth and universe because of my science lessons, $\mathrm{p}=0.0995)$. The $\mathrm{RC}$ control group had a statistically significant higher mean score for statement 1 (I think science at school is boring (a statement written and scored in reverse)), $\mathrm{p}=0.0033$, and was nearly significant on statement 10 (I believe you can learn science in lots of places, not only laboratories or classrooms), $\mathrm{p}=0.0712$.

Table 4.14: Year Two Overall Science Interest Survey (Pre/Post) Results (Appendix A.6)

\begin{tabular}{|c|c|c|c|c|c|c|}
\hline Teacher & $\begin{array}{l}\text { Grade } \\
\text { Level }\end{array}$ & $\begin{array}{l}\text { No. of Pre } \\
\text { Students } \\
\left.\text { (Total }(n)^{*}\right)\end{array}$ & $\begin{array}{l}\text { No. of Post } \\
\text { Students } \\
\left.\text { (Total }(n)^{*}\right)\end{array}$ & $\begin{array}{l}\text { M - Pre } \\
\text { (SD) }\end{array}$ & $\begin{array}{l}\text { M - Post } \\
\text { (SD) }\end{array}$ & $\begin{array}{l}\text { Change in } M \\
\text { (p) }\end{array}$ \\
\hline Experimental & $\begin{array}{l}6 \\
7 \\
8 \\
\end{array}$ & $\begin{array}{l}32 \\
29(85) \\
21\end{array}$ & $\begin{array}{l}31 \\
28(81) \\
22\end{array}$ & $\begin{array}{l}3.769 \\
(0.542)\end{array}$ & $\begin{array}{l}3.800 \\
(0.586)\end{array}$ & $\begin{array}{l}0.031 \\
(0.3607)\end{array}$ \\
\hline RC Control & $\begin{array}{l}6 \\
7 \\
8 \\
\end{array}$ & $\begin{array}{l}29 \\
24(87) \\
31 \\
\end{array}$ & $\begin{array}{l}26 \\
22(79) \\
30 \\
\end{array}$ & $\begin{array}{l}3.930 \\
(0.574)\end{array}$ & $\begin{array}{l}3.944 \\
(0.508) \\
\end{array}$ & $\begin{array}{l}0.014 \\
(0.4335)\end{array}$ \\
\hline $\begin{array}{l}6^{\text {th }} \text { Grade FO } \\
\text { Control }\end{array}$ & 6 & $* * *$ & $72(72)$ & $* * *$ & $\begin{array}{l}2.979 \\
(0.777)\end{array}$ & $* * *$ \\
\hline $\begin{array}{l}7^{\text {th }} \text { Grade FO } \\
\text { Control }\end{array}$ & 7 & $* * *$ & $80(80)$ & $* * *$ & $\begin{array}{l}2.851 \\
(0.729)\end{array}$ & $* * *$ \\
\hline $\begin{array}{l}8^{\text {th }} \text { Grade FO } \\
\text { Control }\end{array}$ & 8 & $* * *$ & $85(85)$ & $* * *$ & $\begin{array}{l}3.124 \\
(0.710)\end{array}$ & $* * *$ \\
\hline
\end{tabular}

*The difference in the total number of students and the breakdown of students per grade comes from the number of students completing the surveys that left the grade level question blank. ${ }^{* * * T h e}$ individual grade control groups did not take the pre-survey. 
Table 4.15: Year Two Individual Statement Science Interest Survey (Pre/Post) Results (Appendix A.6)

\begin{tabular}{|l|l|l|l|l|}
\hline Teacher & Statement & $\begin{array}{l}\mathrm{M}-\text { Pre } \\
\text { (SD) }\end{array}$ & $\begin{array}{l}\text { M - Post } \\
\text { (SD) }\end{array}$ & $\begin{array}{l}\text { Change in M } \\
(\mathrm{p})\end{array}$ \\
\hline Quinn & $\begin{array}{l}\text { 6. I have become more aware of the } \\
\text { environment because of my science } \\
\text { lessons. }\end{array}$ & $\begin{array}{l}3.881 \\
(1.062)\end{array}$ & $\begin{array}{l}4.101 \\
(0.988)\end{array}$ & $\begin{array}{l}0.220 \\
(0.0879)\end{array}$ \\
\hline Quinn & $\begin{array}{l}\text { 11. I am more curious about plants, } \\
\text { animals, earth and universe because } \\
\text { of my science lessons. }\end{array}$ & $\begin{array}{l}3.682 \\
(1.020)\end{array}$ & $\begin{array}{l}3.889 \\
(1.030)\end{array}$ & $\begin{array}{l}0.207 \\
(0.0995)\end{array}$ \\
\hline $\begin{array}{l}\text { RC } \\
\text { Control }\end{array}$ & $\begin{array}{l}\text { 1. I think science at school is boring. } \\
\text { (Statement in reverse) }\end{array}$ & $\begin{array}{l}4.414 \\
(0.751)\end{array}$ & $\begin{array}{l}4.688 \\
(0.463)\end{array}$ & $\begin{array}{l}\mathbf{0 . 2 7 5} \\
\mathbf{( 0 . 0 0 3 3})\end{array}$ \\
\hline $\begin{array}{l}\text { RC } \\
\text { Control }\end{array}$ & $\begin{array}{l}\text { 10. I believe you can learn science in } \\
\text { lots of places, not only laboratories } \\
\text { or classrooms. }\end{array}$ & $\begin{array}{l}4.402 \\
(0.952)\end{array}$ & $\begin{array}{l}4.595 \\
(0.684)\end{array}$ & $\begin{array}{l}0.193 \\
(0.0712)\end{array}$ \\
\hline
\end{tabular}

Overall, on the post-science interest surveys, the experimental group had a statistically significant higher mean score than all FO control groups $\left(6^{\text {th }}\right.$ grade FO control, $\mathrm{p}<0.0005 ; 7^{\text {th }}$ grade FO control, $\mathrm{p}<0.0005 ; 8^{\text {th }}$ grade FO control, $\mathrm{p}<0.0005$ ). When taken on a statement-by-statement basis, the experimental group had a statistically significant higher mean score on all of the statements compared to all of the FO control groups, with one exception. Statement 15 (Science is my favorite class), received a higher mean score from the $8^{\text {th }}$ grade FO control group than the experimental group.

When the experimental group was compared with the RC control group, the overall mean scores, on the post-science interest survey, were nearly significantly higher for the $\mathrm{RC}$ control group $(\mathrm{p}=0.0501)$. When taken on a statement-bystatement basis, none of the mean statement scores were statistically significant or nearly statistically significant.

When the post-survey scores were further analyzed by gender, the $6^{\text {th }}$ grade FO control group had statistically significant higher mean score by the females than 
males $(\mathrm{p}=0.0457)$ (Table 4.16). None of the other test groups had any significant differences based on gender.

Table 4.16: Year Two Post-Science Interest Survey Results Displayed based on Gender (Appendix A.6)

\begin{tabular}{|c|c|c|}
\hline $\begin{array}{c}\text { Teacher } \\
\mathrm{n}^{*} \text { Female } \\
\mathrm{n}^{*} \text { Male }\end{array}$ & $\begin{array}{c}\text { M (SD) } \\
\text { Female } \\
\text { Male }\end{array}$ & $\mathrm{p}$ \\
\hline Quinn & & \\
32 & $3.722(0.578)$ & 0.1792 \\
48 & $3.847(0.591)$ & \\
\hline RC Control & & \\
34 & $3.867(0.521)$ & 0.1222 \\
45 & $4.003(0.490)$ & \\
\hline $6^{\text {th }}$ Grade FO Control & $3.163(0.758)$ & $\mathbf{0 . 0 4 5 7}$ \\
36 & $2.848(0.748)$ & $* * \mathbf{F}$ \\
34 & & \\
$7^{\text {th }}$ Grade FO Control & $2.731(0.568)$ & 0.1490 \\
30 & $2.912(0.802)$ & \\
44 & & \\
\hline $8^{\text {th }}$ Grade FO Control & $3.211(0.637)$ & 0.1235 \\
42 & $3.026(0.757)$ & \\
37 &
\end{tabular}

*n values may not be equal to initial $n$ values given in Table 4.15 due to missing responses to the gender question. ${ }^{* *} \mathrm{~F}=$ statistically significant higher scores for females as compared to males in their class.

Analyzing the post-surveys for significance by grade level reveals that when the experimental group is divided into its component grades $\left(6^{\text {th }}, 7^{\text {th }}\right.$, and $\left.8^{\text {th }}\right)$, each experimental grade has a statistically significant higher score than the FO control grades for the overall mean average (Table 4.17). The grade-by-grade comparison was not done between the experimental and RC control because of already exhibited similar scores (Table 4.14). 
Table 4.17: Year Two Post-Science Interest Survey Results Displayed based on Grade (Appendix A.6)

\begin{tabular}{|l|c|c|c|c|}
\hline \multicolumn{1}{|c|}{ Teacher } & Grade Level $-\mathrm{n}^{*}$ & $\mathrm{M}(\mathrm{SD})$ & $\begin{array}{c}\text { Difference in M } \\
\text { (Quinn - Control) }\end{array}$ & $\mathrm{p}$ \\
\hline Quinn & $6-31$ & $3.676(0.589)$ & 0.697 & $<\mathbf{0 . 0 0 5}$ \\
& $7-28$ & $3.641(0.543)$ & 0.790 & $<\mathbf{0 . 0 0 5}$ \\
& $8-22$ & $4.178(0.450)$ & 1.054 & $<\mathbf{0 . 0 0 5}$ \\
\hline $6^{\text {th }}$ Grade & $6-72$ & $2.979(0.777)$ & & \\
FO Control & & & & \\
\hline $7^{\text {th }}$ Grade & $7-80$ & $2.851(0.729)$ & & \\
FO Control & & & & \\
\hline $8^{\text {th }}$ Grade & $8-85$ & $3.124(0.710)$ & & \\
FO Control & & & & \\
\hline
\end{tabular}

*n values may not be equal to initial $n$ values given in Table 4.14 due to missing responses to the gender question.

\section{Science Interest Qualitative Results}

In Year One, the students were asked what they want to be when they grow up. Of the 10 responses, 8 fell into STEM fields (marine biologist, engineer, naturalist or teacher, bioengineer, physicist, geneticist, medical doctor, crime scene investigator). The parents, as part of Year One's focus group, were asked what their child wants to be when he/she grows up. Of the 3 responses, all three were in STEM fields (marine biologist, geneticist working with plant DNA, geneticist). In Year Two (Appendix B.6), the same question was asked of the parents. Of the 8 responses, 7 were in the STEM fields (veterinarian, physician, curing HIV or cancer, computer graphics, video game designer, architect or engineer, and work like the FIT group does). 


\section{CHAPTER 5: DISCUSSION}

The students of Rachel Carson Middle School (RCMS) scored higher than the students of Five Oaks Middle School (FOMS) on both the stewardship survey (Table 4.3) and the science interest survey (Table 4.14). The difference in these scores can be attributed to a number of variables including: different school themes (environmental vs. traditional), exposure to outdoor experiences (numerous vs. few), and science teacher training (TEC vs. unknown).

RCMS attracts students who have an initial interest in environmental science and the school hones this interest over the course of the year. The students take part in numerous, long-term environmental projects (i.e. tree tagging, plant identification, invasive plant removal, wetland monitoring and restoration (Appendix B.7)) and restoration activities, with outdoor events happening nearly every week. FOMS is a traditional middle school without an environmental theme. The students do not have very many opportunities to learn and work outdoors though some science teachers do give their students limited outdoor experiences on an irregular basis (i.e. working on litter clean up for Earth Day, taking part in wetland monitoring, and Project Feederwatch (Appendix B.7)).

One of the science teachers at RCMS, Quinn, has received extensive training in the use of different ecology protocols by attending TEC for the past 2 years. The training and experiences he has had have been implemented into his curriculum and have been shared with other science teachers at RCMS. The science teachers of FOMS have not received such training. 


\section{Stewardship Analysis}

\section{Overall Stewardship Effects on the Experimental Class - Significant Findings}

In Year Two, there were 5 statements on the environmental stewardship survey where the experimental group had a statistically significant or close to significant change in their mean scores from the pre- to the post-surveys. This change is reinforced by responses from students (Appendices B.4 and B.5), parents (Appendix B.6), and teachers (Appendix B.7) in the focus group sessions.

\section{Specific Theme 1. Naturalist Learning - Significant Findings}

One of the findings that were significant was the students' interest in naturalist learning. Students reported enjoyment of finding signs of animals and learning about plants while they are outdoors (Statement 3) and they like the chance to be outdoors (Statement 16). This reflects that, over the course of the year, given the numerous opportunities to experience and learn in the natural world, the students are still excited to learn more and enjoy the continued opportunities to go outside. As Louv (2005, p. 140) describes, “"humans seldom value what they cannot name."' Using the outdoors as for a site for science continued to spark their interest, over the year, to both learn and find out more about their surroundings.

Because they are often in natural spaces, these students are more aware of their surroundings and know the signs to look for that suggests animal activity or changes in plant phenology. Some of these signs are made explicitly clear by the teacher (i.e. here is an example of a leaf emerging). Students commented that they 
noticed changes in their environment, over the course of the year, and seemed excited about these observations.

Even though the group has battled poor weather conditions (i.e. rain, snow, mud, cold) throughout the year, the students are still excited to be outdoors during school. Learning outdoors has been viewed as important in the field of education with the naming of an eighth intelligence, the naturalist intelligence (Lach et al. 2003). Students also take this interest home and encourage their family to take them outdoors whenever possible.

Students in the FO control group also express high scores in wanting the chance to be outdoors. This opportunity is not often being met in the traditional schools and should be more incorporated into the curriculum in order for this interest to be met for the students.

\section{Specific Theme 2. Environmental Efficacy-Significant Findings}

Another variable that changed significantly was environmental efficacy. The students also believe their work in natural areas is doing something useful (Statement 12). They enjoy seeing the results of their labor and believe that they are making a difference in the natural environment. Seeing the results of their work, these students have an increased capacity to understand other environmental problems around them. They are not stifled and feel helpless in learning about these problems, but rather they are encouraged, excited, and show a positive attitude to come up with solutions. The students develop both confidence and competence in the field of environmental science because they are given time to 
master skills and fully embrace the projects at hand. They feel that by working together, the problems can be corrected. Students are taking steps to change their behavior and feel they can bring about change in their environment. Some additional examples, include (all quotations are paraphrased unless in quotation marks):

- $\quad$ Student: I feel like we can all make a difference.

- $\quad$ Student: I try to do little stuff like recycling, taking shorter showers, keeping the water on for only short periods of time - I think that small steps add up to a big step.

- $\quad$ Parent: They are often spotting [invasive] blackberry and ivy and saying how they could fix that.

This sense of purpose is important for those students not a part of the environmental middle school, as well. As expressed on the stewardship surveys by the FO control groups, those with past environmental experiences exhibited stronger stewardship attitudes (Table 4.6). Those students with this past experience have been greatly influenced by their experiences, contributing to their environmental identity.

The experimental group of students also reported more awareness of their impacts to natural environments (Statement 18). This awareness is important because it works to shape their attitudes and, more importantly, their behaviors. In the classroom, the students are taught about energy usage and sources of pollution, among other environmental problems. When they are in the field, they learn about the spread of invasives and ways of preventing such spread. Because they know and care about how their choices impact the natural landscape, they are more likely to make less destructive decisions both now, and hopefully, into the future. 


\section{Specific Theme 3. Changes in Environmental Perception - Significant Findings}

The final variable that changed significantly was changes in environmental perception. The experimental students can recognize unhealthy landscapes (like ones with invasive species) (Statement 17) because of the work they have done in them and their exposure to both healthy and unhealthy environments. The students are exposed to different environmental sites, on a regular basis, thus allowing them to see different levels of environmental degradation. At the sites, the students are explicitly taught how to correctly influence the sites (i.e. correct techniques for ivy and invasive blackberry removal) and this has then given them ownership and skill in how to carry out the work thus allowing them to affect change in the sites.

Due to urbanization, we often do not realize how much the natural environment has been altered. These students have developed a sense of what a disturbed environment really is and understand the importance of the natural, more pristine landscapes that they have been exposed to.

- Student: After working at SOLV and in Forest Park, I'm happy to see places [without invasives] like that now and I want to change my own to be like that.

The above changes from the pre- to the post-survey (supplemented by statements from the focus groups), show that the students have an increased sense of caring and protection for the natural world, an example of increased stewardship attitudes. Their passion about the environment is important to note because they truly feel that they can illicit change by working to improve natural settings and their continued work and exposure only seems to fan this passion. 
Results from the experimental group, when compared with the groups from Year One, show a larger number of changes from the pre- to the post-stewardship survey. Quinn's students had statistically significant changes from the pre- to the post-survey on two statements, in Year One (Table 4.2). While other teachers (Marquardt, Carnes', and Cooper) may have had one or two questions go through a statistically significant change, but the overall results were not very convincing.

\section{Past Environmental Experiences - Significant Findings}

The FO control group students having had past environmental experience also had a higher mean stewardship score than their fellow classmates who reported not having past environmental experience (Table 4.6). The same was true for the student groups of Year One (Table 4.5). This demonstrates the effect that experiences and work on restoration and conservation activities, in the natural world, can have on students and their environmental stewardship attitude. While few details of the reported activities were given, the fact that the students reported that they had taken part in such work speaks to them having internalized the experiences and all that was learned during the experience. These activities are already influencing the students' stewardship attitude and may continue to shape their behaviors as adults. This is supported by Louv (2005, p. 149), "Studies of environmental activists in locales as diverse as Kentucky and Norway indicate that childhood experiences are significant precursors for adult activism on behalf of the environment." 


\section{Gender - Significant Findings}

The survey results show (Tables 4.7, 4.8, 4.9, and 4.10) that females, more than males, have higher mean scores in a number of the stewardship areas, especially respect for the environment and attachment to place. This could be due to the fact that females form stronger, more mature attachments at a younger age than their male counterparts. It could also be due to females being more aware, and therefore better able to report, their feelings (especially those feelings of empathy which are so important to environmental stewardship) in these areas than males of the same age group. With this in mind, schools, teachers and programs should give all students, especially females, the chance to take part in long-term projects and to develop their environmental stewardship attitudes.

\section{Grade}

There was no statistically significant difference between the experimental group and the FO control group based on grade level (Table 4.11). In all grades, the experimental group had higher scores in all areas of stewardship than the FO control groups. This demonstrates that there is not a stewardship change that naturally occurs in students of a given grade but rather the students must be influenced by something (i.e. environmental choices made in the home, lessons taught in school, ecology projects participated in, etc.).

\section{Hypothesis Results: Stewardship}

We found that student participation in a long-term, ecology-based project on a school forest did lead to increased environmental stewardship attitudes, 
supporting the proposed hypothesis. As stated earlier, the need for environmentally conscious students is great given the current state of ecological health of the planet. As Louv (2005, p. 155) describes, "Surely children need a quality attachment to land not only for their own health, but in order to feel compelled to protect nature as adults - not only as common-sense conservationists, but as citizens and as voters." Without students having a care or concern for the natural world, who will protect and care for it in the future? In order to have bright students in the STEM fields, there must be exposure to such fields and the possible careers in them, as well. Developing a passion for the environment and an interest in STEM fields, in students, may be the perfect combination for the future outcome of our planet.

\section{Hypothesis Results: Teacher Training}

While not directly measured in this study, the training that a teacher receives at the summer workshop, Teaching Ecosystem Complexity through Field Science Inquiry (TEC), as well as the support that they receive during the following school year, helps to encourage better field experiences for their students. Though there was not a significant difference in stewardship or science interest mean scores between the experimental group and the RC controls (Tables 4.3 and 4.14), many of the ideas and projects that were implemented for both groups of RCMS students came about because of Quinn's participation and experience in the summer program. Because he received direct training from scientists and carried out a longterm project himself, he was able to take what he learned back into the classroom and implement new curricula for his students. 
Research from past TEC programs mirror the experiences that Quinn's students had in the field. Statistically significant findings $(\mathrm{p} \leq 0.05)$ on 2009 postsurveys of teacher practices indicate that students of TEC participants had statistically significant increased opportunities to learn about ecology and the environment, collect data in the field related to questions students had posed, and to learn ecology concepts.

Perhaps picking up on his own interest in the natural world, Quinn's students were more likely to express their interest in learning about the flora and fauna in the environment (Statement 3), spending time outdoors (Statement 16), recognizing unhealthy landscapes (Statement 17), and in identifying different species (Statement 25) than their counterparts that took part in the same projects but were lead by a different teacher (Table 4.1).

Using the program's website, www.ecoplexity.org, Quinn also knew well how to draw from the resources found there (protocols, background information on ecology topics, etc.) and implement that resource in his curriculum planning.

\section{Elements of Successful Student Projects}

Building off of what Quinn was able to create for his students with their long-term projects, the short-comings of other projects are made clear. While well intentioned, a number of the teachers from Year One were unable to create meaningful projects for their students.

The students in Carnes' class had exposure to natural spaces with free, open inquiry projects and they likely got too lost and frustrated in the details, and likely 
had too many problems in execution of protocols, to properly take in all of the effects of their environment. Their attention was likely on problem solving rather than experiencing their surroundings and developing stewardship awareness of their locations. This is in contrast to the students in the experimental group who were often given structured tasks, with some flexibility, to carry out while outdoors. Though the idea of complete flexibility for the students in entirely, unaided, open inquiry projects may sound appealing, and the assumption that the students will take ownership and have an increased interest because it is "their" project, the reality is that students need structure and strong guidance. Creating these open inquiry projects for their students reflects great trust and confidence in their students, on behalf of the teacher. As we have seen with other teachers, in the past, it takes time for them to develop this awareness of need for scaffolding by their students.

Though the teachers at TEC carried out open-inquiry projects, they did so within the confines of their specific area (i.e. moth, invertebrate, or vegetation studies). The teachers first collected data with the scientist, in order to become comfortable with the techniques and protocols, and then posed questions based on the data collected. Analysis of their question and assistance with additional data collection and project design were all aided by a support network of scientists and other professionals. It was this type of open inquiry that was recommended to the teachers to implement with their students. 
Other shortcomings of other projects included the lack of importance and regular exposure placed on the projects. With all of the other curriculum demands, the teachers often did not fully embrace the project and reference it enough with their students in order for the students to be aware of its importance in the classroom.

Those teachers that did not have constant exposure to environmental projects (Carnes, Marquardt, Cooper, and all FO control groups), had lower scores on their environmental stewardship surveys than those teachers who had consistent project exposure for their students (experimental and RC control group). Because the students were always aware of their project and constantly working towards a goal (i.e. removing invasives, planting trees, etc.) the students were able to remain focused and interested. In Marquardt's case, given the relatively few site visits (3), while the long-term nature of the project was there, the frequency of attention to the project was rather low. Because of this inattention, the students failed to see the connection in their fieldwork and likely did not have a strong attachment to place. While wonderful that the students were given 3 site visits (much more than in a "normal" class), more attention to the project is recommended. In Cooper's case, the students taking the pre- and post-surveys, as well as carrying out the fieldwork, were not necessarily the same students, as this was an afterschool, high school club where the students are very busy with a number of activities. Again, the frequency and focus on the project was lacking. 
The third shortcoming is the overall infrequency of visits to natural areas. The experimental group had a number of visits to natural spaces, often at least one per week, throughout the school year. This gave the students attachment to a number of outdoor places. Even if the visits were not to their study sites, the experimental students were constantly able to make comparisons between their sites and the other locations visited. This was lacking in many of the other projects. With the FO control groups, while some teachers had limited outdoor experiences for their students (i.e. working on litter clean up for Earth Day, taking part in wetland monitoring, and Project Feederwatch (Appendix B.7)), the focus is most certainly not on getting students outdoors as much as possible. The same was true for Carnes, Marquardt, and Cooper in Year One. While the importance of teaching students outdoors has been presented in other research, the message does not seem to have been grasped by traditional schooling systems. Unfortunately, according to Louv (2005, p. 2), "Our society is teaching young people to avoid direct experience in nature."

This is noteworthy because there is a strong interest in going outdoors by the students. All of the grades of the FO control groups reported a higher than average mean score for Statement 16, I like the chance to be outdoors, than for most other statements on the post-stewardship survey (Table 4.1). The students show interest in a change of scenery and would like the opportunity to take their education out of the brick buildings that it has been confined to for decades. 


\section{Recommendations for Other Teachers and Schools}

A number of recommendations can be made to other teachers and schools that want to increase their students' environmental stewardship attitudes, based on this study, they include:

1. Focusing on middle school students: Middle school students have more flexibility in their schedules and curriculum than high school students do, both during and after school, allowing for more opportunities in the field and outdoor experiences. Students at this age are still dependent on their parents for transportation (i.e. they cannot drive) and the parents are more likely to be involved in the schooling process. This additional, parental support gives teachers greater opportunities to have more fieldtrips and field experiences with their students.

2. Teacher training: Well designed, effective, hands-on teacher training is very important in order to give teachers the confidence that they need to participate in fieldwork with their students and work with them outdoors. Having the teachers receive direct instruction and work beside scientists, without having students present, allows them to focus fully on the information to be learned.

3. Focused, long-term projects for students: A focused, long-term project may take place over the course of a school year or in a couple of weeks. The importance falls on the project being fully embraced by the teacher (i.e. having graded work attached to the project, providing scaffolding for 
student research, allowing students the opportunity to develop a sense of place, and allowing the students to have a number of site visits). One suggestion is allowing students to use a research area near their school so the frequency of visitation can be increased. Facilitating the students to take ownership of a nearby natural area encourages stewardship of the area as well as pride in seeing changes occurring due to their work.

4. Support to teachers for project implementation: Providing graduate students, or other available individuals, to assist the teacher in the implementation of their student projects is very important. Because of the pressures and schedules that teachers are under, the extra support can help them find time to implement their projects and to talk through challenges and/or concerns.

5. Ecological projects and/or restoration: Giving the students the opportunity to do some sort of ecological restoration work, as a component of their project, is very important to their environmental stewardship attitude. The experience and skills gained have been shown to remain with them in the future and may influence choices that they make.

\section{Recommendations for Further Research}

These results could be improved by further research in a variety of areas including: survey development and analysis, differences in stewardship attitudes between female and male students, and following the students in a longitudinal study. 
There are still areas for improvement on both of the survey tools that were used in this study. The tools could be improved better to capture home influences on stewardship attitudes as well as students' prior interest in environmental topics and issues. Carrying out factor analysis on the survey responses may help to shed insight on other improvements and changes that could be made. Placing the survey online for the students to take in a computer lab would also aid in more complete answering of the survey statements and be a time saver for the researcher, as a suggestion.

More research should be done looking at the stewardship differences between female and male students. While our results suggest that overall, females have significantly different responses in certain aspects of stewardship, the cause for these differences is still unclear.

It would be very interesting to continue with a longitudinal study of these students and see if their environmental passion remains with them and/or if they choose careers in the STEM fields. This could be done with careful surveying over the course of the next $10+$ years and ongoing conversations with students who are graduates of both RCMS and other schools where long-term ecology projects have been carried out. 


\section{CHAPTER 6: CONCLUSION}

Environmental stewardship is an important attitude to develop in youth because the health and future of our planet depends on having environmentally conscious and active citizens defending the natural ecosystems that support the processes that provide the foundation for all life. There are a number of areas of environmental stewardship including: 1 . respect for the environment, 2 . desire to learn about the environment, 3. interest in sharing environmental knowledge with others, 4. attachment to place, and 5. improving degraded environments and protecting the environment. The specific areas that experienced change in this study include naturalist learning, environmental efficacy, and changes in environmental perception. All of these areas work in conjunction with one another and foster a well-round environmental steward of the earth.

Over the course of the two year study, there were significant changes in student stewardship attitudes because of their participation in long-term, ecological projects under the guidance of their science teacher. The results indicate that middle school students, who report having taken part in an environmental project in the past score higher on the environmental stewardship survey. Also, female students tend to score higher in specific areas than males. There was not found to be significant changes based on grade level. Some middle school students attending the environmentally-themed middle school expressed significant changes, after they had completed their projects, in the areas of learning about the natural world, feelings that their work is doing something useful for the natural world, 
enjoying being outdoors, recognizing unhealthy landscapes, and being more aware of their personal impacts to the natural world. All of these factors show the impact that regular experiences in natural settings can have on students' environmental stewardship attitudes.

Giving science teachers the opportunity to learn about long-term projects through direct, hands-on experience, like taking part in the TEC program, has been proven to increase their students' interest in science and understanding of ecological complexity. This paired with the skills the teachers gain in how to carry out successful, long-term ecology projects with their students, results in increased student environmental stewardship attitudes.

Those student projects that are focused, with structured tasks for students, as opposed to entirely open inquiry based, are highly successful. The project must also have constant exposure, and importance, and often be discussed in the classroom, in order for the students to embrace the project and understand its importance. The third element that the project must contain is frequency of visits to natural areas. The visits do not all have to be to the project site but just by having more opportunities to experience natural spaces, the students will compare and contrast the differences in their project sites and those other sites visited. For easier implementation of the project, the projects should focus on middle school students, the teachers should receive well designed, effective, handson teacher training, the projects should be focused and long-term (at least two weeks long), the teachers should receive support for implementation, and the 
projects should include a restoration component. These factors, paired with those of successful projects, can influence and increase students' environmental stewardship attitudes and increase their interest in environmental issues. Since students will be the ones taking over the responsibility for environmental protection in the future, it is imperative that they have a strong sense of environmental stewardship. The duty to make sure that this sense is honed falls to parents and teachers. The environmental attitudes of students can be impacted; it just takes parties interested and passionate in order to bring about this change. 


\section{REFERENCES}

Barnett, M., Lord, C., Strauss E., Rosca, C., Langford, H., Chavez, D. and Deni, L. 2006. Using the urban environment to engage youths in urban ecology field studies. The Journal of Environmental Education 37(2): 3-11.

Bodzin, A. M. 2008. Integrating instructional technologies in a local watershed investigation with urban elementary learners. The Journal of Environmental Education 39(2): 47-57.

Clayton, S. and Myers, G. 2009. Conservation psychology: understanding and promoting human care for nature. West Sussex, UK: Wiley-Blackwell.

Cook, V. 2008. The field as a 'pedagogical resource'? A critical analysis of students' affective engagement with the field environment. Environmental Education Research 14(5): 507-517.

Coyle, K. 2005. Environmental literacy in America: what ten years of NEETF/Roper research and related studies say about environmental literacy in the U.S. The National Environmental Education and Training Foundation, Washington, DC.

Cronin-Jones, L. L. 2000. The effectiveness of schoolyards as sites for elementary science instruction. School Science and Mathematics 100(4): 203-211.

Crawford, B.A. 2000. Embracing the essence of inquiry: new roles for science teachers. Journal of Research in Science Teaching 37(9): 916-937.

Dresner, M. 2009. Undergraduate stewardship survey results. Unpublished. 
Foster, J. 2005. Making sense of stewardship: metaphorical thinking and the environment. Environmental Education Research 11(1): 25-36.

Fraser, J., Clayton, S., Sickler, J. and Taylor, A. 2009. Belonging at the zoo: retired volunteers, conservation activism and collective identity. Aging and Society 29: $351-368$.

Goodwin, N. 2003. Five kinds of capital: useful concepts for sustainable development. Global Development and Environment Institute Working Paper \#03-07.

Johnson, E. A. and Catley, K. M. 2009. Urban soil ecology as a focal point for environmental education. Urban Ecosyst 12: 79-93.

Kenney, J. L., Militana, H. P. and Donohue, M. H. 2003. Helping teachers to use their school's backyard as an outdoor classroom: a report on the watershed learning center program. The Journal of Environmental Education 35(1): $18-26$.

Lach, C., Little, E. and Nazzaro, D. 2003. From all sides now: weaving technology and multiple intelligences into science and art. Learning and Leading with Technology 30(6): 32-59.

Louv, R. 2005. Last Child in the Woods: Saving our Children from Nature-Deficit Disorder. Chapel Hill: Algonquin Books of Chapel Hill.

Manfredo, M. and Teel, T. 2008. Integrating concepts: demonstration of a multilevel model for exploring the rise of mutualism value orientations in postindustrial society. Who Cares about Wildlife. New York: Spring Press. 
Manzanal, R. F., Barreiro, L. M. R. and Jimenez, M. C. 1999. Relationship between ecology fieldwork and student attitudes toward environmental protection. Journal of Research in Science Teaching 36(4): 431-453.

Newell, P. 1997. A cross-cultural examination of favorite places. Environment and Behavior 29: 495-514.

Palmberg, I. E. and Kuru, J. 2000. Outdoor activities as a basis for environmental responsibility. The Journal of Environmental Education 31(4): 32-36.

Palmer, J. and Suggate, J. 1996. Influences and experiences affecting the proenvironmental behavior of educators. Environmental Education Research 2(1): 109-122.

Prescott-Allen, R. 2001. Chapter 1 and Chapter 2. The Wellbeing of Nations: A Country-by-Country Index of Quality of Life and the Environment. Washington, Covelo, London: Island Press.

Ryan, R. L. 2005. Exploring the effects of environmental experience on attachment to urban natural areas. Environment and Behavior 37(3): 3-42.

Ryan, R. L., Kaplan, R. and Grese, R. E. 2001. Predicting volunteer commitment in environmental stewardship programmes. Journal of Environmental Planning and Management 44(5): 629-648.

Seymour, E. and Hewitt, N. M. 1997. Talking about leaving: why undergraduates leave the sciences. Westview, Boulder, Colorado. 
Stern, M. J., Powell, R. B., and Ardoin, N. M. 2008. What difference does it make? assessing outcomes from participation in a residential environmental education program. The Journal of Environmental Education 39(4): 31-43.

Taylor, D. J., Holly, M. L. and Zachariah, S. 2008. Landscaping locally: fostering stewardship with real science in high school curricula. Cities and the Environment 1(2): 1-12. 


\section{APPENDICES}

\section{APPENDIX A: SURVEY INSTRUMENTS}

\section{Appendix A.1: 15-Question Pre-Stewardship Survey (Year One) Stewardship Survey Pre}

Teacher's name:

Grade

School:

Check whether you are: Male

Female

Have you ever participated in any activities lead by environmental organizations: YES

Have you participated in ecological restoration activities before? YES

$\mathrm{NO}$

We're interesting in finding out what you think about science. Read each statement, and then circle the response that best describes how true the statement is for you.

\begin{tabular}{|c|c|c|c|c|}
\hline $\begin{array}{l}\text { 1. When I can, I go outdoors to } \\
\text { natural environments in my } \\
\text { free time. }\end{array}$ & $\begin{array}{l}\text { Definitely } \\
\text { NOT true for } \\
\text { me }\end{array}$ & $\begin{array}{l}\text { True for me } \\
\text { once in a } \\
\text { while }\end{array}$ & $\begin{array}{l}\text { Sometimes } \\
\text { true for me }\end{array}$ & $\begin{array}{l}\text { Definitely } \\
\text { TRUE for } \\
\text { me }\end{array}$ \\
\hline $\begin{array}{l}\text { 2. I enjoy talking to my friends } \\
\text { and/or family about what } \\
\text { I'm doing in science class. }\end{array}$ & $\begin{array}{l}\text { Definitely } \\
\text { NOT true for } \\
\text { me }\end{array}$ & $\begin{array}{l}\text { True for me } \\
\text { once in a } \\
\text { while }\end{array}$ & $\begin{array}{l}\text { Sometimes } \\
\text { true for me }\end{array}$ & $\begin{array}{l}\text { Definitely } \\
\text { TRUE for } \\
\text { me }\end{array}$ \\
\hline $\begin{array}{l}\text { 3. I don't really like } \\
\text { discovering animals or } \\
\text { plants while outdoors. }\end{array}$ & $\begin{array}{l}\text { Definitely } \\
\text { NOT true for } \\
\text { me }\end{array}$ & $\begin{array}{l}\text { True for me } \\
\text { once in a } \\
\text { while }\end{array}$ & $\begin{array}{l}\text { Sometimes } \\
\text { true for me }\end{array}$ & $\begin{array}{l}\text { Definitely } \\
\text { TRUE for } \\
\text { me }\end{array}$ \\
\hline $\begin{array}{l}\text { 4. I feel that natural areas, like } \\
\text { parks, preserves, wildlife } \\
\text { refuges, are important. }\end{array}$ & $\begin{array}{l}\text { Definitely } \\
\text { NOT true for } \\
\text { me }\end{array}$ & $\begin{array}{l}\text { True for me } \\
\text { once in a } \\
\text { while }\end{array}$ & $\begin{array}{l}\text { Sometimes } \\
\text { true for me }\end{array}$ & $\begin{array}{l}\text { Definitely } \\
\text { TRUE for } \\
\text { me }\end{array}$ \\
\hline $\begin{array}{l}\text { 5. I am making a meaningful } \\
\text { contribution to helping the } \\
\text { environment in this project. }\end{array}$ & $\begin{array}{l}\text { Definitely } \\
\text { NOT true for } \\
\text { me }\end{array}$ & $\begin{array}{l}\text { True for me } \\
\text { once in a } \\
\text { while }\end{array}$ & $\begin{array}{l}\text { Sometimes } \\
\text { true for me }\end{array}$ & $\begin{array}{l}\text { Definitely } \\
\text { TRUE for } \\
\text { me }\end{array}$ \\
\hline $\begin{array}{l}\text { 6. I would like to help (or have } \\
\text { already helped) create } \\
\text { natural areas/landscapes at } \\
\text { home. }\end{array}$ & $\begin{array}{l}\text { Definitely } \\
\text { NOT true for } \\
\text { me }\end{array}$ & $\begin{array}{l}\text { True for me } \\
\text { once in a } \\
\text { while }\end{array}$ & $\begin{array}{l}\text { Sometimes } \\
\text { true for me }\end{array}$ & $\begin{array}{l}\text { Definitely } \\
\text { TRUE for } \\
\text { me }\end{array}$ \\
\hline $\begin{array}{l}\text { 7. I would be upset if a natural } \\
\text { area where I worked was } \\
\text { destroyed. }\end{array}$ & $\begin{array}{l}\text { Definitely } \\
\text { NOT true for } \\
\text { me }\end{array}$ & $\begin{array}{l}\text { True for me } \\
\text { once in a } \\
\text { while }\end{array}$ & $\begin{array}{l}\text { Sometimes } \\
\text { true for me }\end{array}$ & $\begin{array}{l}\text { Definitely } \\
\text { TRUE for } \\
\text { me }\end{array}$ \\
\hline $\begin{array}{l}\text { 8. I think you can get along } \\
\text { fine in every day life } \\
\text { without spending time in } \\
\text { nature. }\end{array}$ & $\begin{array}{l}\text { Definitely } \\
\text { NOT true for } \\
\text { me }\end{array}$ & $\begin{array}{l}\text { True for me } \\
\text { once in a } \\
\text { while }\end{array}$ & $\begin{array}{l}\text { Sometimes } \\
\text { true for me }\end{array}$ & $\begin{array}{l}\text { Definitely } \\
\text { TRUE for } \\
\text { me }\end{array}$ \\
\hline $\begin{array}{l}\text { 9. I think I would help protect } \\
\text { a natural area if I had a } \\
\text { chance to work there. }\end{array}$ & $\begin{array}{l}\text { Definitely } \\
\text { NOT true for } \\
\text { me }\end{array}$ & $\begin{array}{l}\text { True for me } \\
\text { once in a } \\
\text { while }\end{array}$ & $\begin{array}{l}\text { Sometimes } \\
\text { true for me }\end{array}$ & $\begin{array}{l}\text { Definitely } \\
\text { TRUE for } \\
\text { me }\end{array}$ \\
\hline $\begin{array}{l}\text { 10. If I had to move away, I } \\
\text { would miss the natural areas } \\
\text { I had visited near my home } \\
\text { or school. }\end{array}$ & $\begin{array}{l}\text { Definitely } \\
\text { NOT true for } \\
\text { me }\end{array}$ & $\begin{array}{l}\text { True for me } \\
\text { once in a } \\
\text { while }\end{array}$ & $\begin{array}{l}\text { Sometimes } \\
\text { true for me }\end{array}$ & $\begin{array}{c}\text { Definitely } \\
\text { TRUE for } \\
\text { me }\end{array}$ \\
\hline
\end{tabular}




\begin{tabular}{|l|c|c|c|c|}
\hline $\begin{array}{l}\text { 11. I would like to do } \\
\text { restoration work in a local } \\
\text { natural area. }\end{array}$ & $\begin{array}{c}\text { Definitely } \\
\text { NOT true for } \\
\text { me }\end{array}$ & $\begin{array}{c}\text { True for me } \\
\text { once in a } \\
\text { while }\end{array}$ & $\begin{array}{c}\text { Sometimes } \\
\text { true for me }\end{array}$ & $\begin{array}{c}\text { Definitely } \\
\text { TRUE for } \\
\text { me }\end{array}$ \\
\hline $\begin{array}{l}\text { 12. I would like to help protect } \\
\text { natural areas in other parts } \\
\text { of the country. }\end{array}$ & $\begin{array}{c}\text { Definitely } \\
\text { NOT true for } \\
\text { me }\end{array}$ & $\begin{array}{c}\text { True for me } \\
\text { once in a } \\
\text { while }\end{array}$ & $\begin{array}{c}\text { Sometimes } \\
\text { true for me }\end{array}$ & $\begin{array}{c}\text { Definitely } \\
\text { TRUE for } \\
\text { me }\end{array}$ \\
\hline $\begin{array}{l}\text { 13. I think I would bring family } \\
\text { and friends to the natural } \\
\text { area where I worked to show } \\
\text { them around. }\end{array}$ & $\begin{array}{c}\text { Definitely } \\
\text { NOT true for } \\
\text { me }\end{array}$ & $\begin{array}{c}\text { True for me } \\
\text { once in a } \\
\text { while }\end{array}$ & $\begin{array}{c}\text { Sometimes } \\
\text { true for me }\end{array}$ & $\begin{array}{c}\text { Definitely } \\
\text { TRUE for } \\
\text { me }\end{array}$ \\
\hline $\begin{array}{l}\text { 14. I feel a strong emotional } \\
\text { connection to natural areas. }\end{array}$ & $\begin{array}{c}\text { Definitely } \\
\text { NOT true for } \\
\text { me }\end{array}$ & $\begin{array}{c}\text { True for me } \\
\text { once in a } \\
\text { while }\end{array}$ & $\begin{array}{c}\text { Sometimes } \\
\text { true for me }\end{array}$ & $\begin{array}{c}\text { Definitely } \\
\text { TRUE for } \\
\text { me }\end{array}$ \\
\hline $\begin{array}{l}\text { 15. I like to learn about natural } \\
\text { ecosystems, the plants and } \\
\text { animals that live in them. }\end{array}$ & $\begin{array}{c}\text { Definitely } \\
\text { NOT true for } \\
\text { me }\end{array}$ & $\begin{array}{c}\text { True for me } \\
\text { once in a } \\
\text { while }\end{array}$ & $\begin{array}{c}\text { Sometimes } \\
\text { true for me }\end{array}$ & $\begin{array}{c}\text { Definitely } \\
\text { TRUE for } \\
\text { me }\end{array}$ \\
\hline
\end{tabular}




\section{Appendix A.2: 15-Question Post-Stewardship Survey (Year One) Stewardship Survey Post}

Teacher's name:

Grade

School:

Check whether you are: Male

Female

Have you ever participated in any activities lead by environmental organizations: YES $\mathrm{NO}$

Have you participated in ecological restoration activities before? YES $\mathrm{NO}$

We're interesting in finding out what you think about science. Read each statement, and then circle the response that best describes how true the statement is for you.

\begin{tabular}{|c|c|c|c|c|}
\hline $\begin{array}{l}\text { 1. When I can, I go outdoors to } \\
\text { natural environments in my } \\
\text { free time. }\end{array}$ & $\begin{array}{l}\text { Definitely } \\
\text { NOT true for } \\
\text { me }\end{array}$ & $\begin{array}{l}\text { True for me } \\
\text { once in a } \\
\text { while }\end{array}$ & $\begin{array}{l}\text { Sometimes } \\
\text { true for me }\end{array}$ & $\begin{array}{l}\text { Definitely } \\
\text { TRUE for } \\
\text { me }\end{array}$ \\
\hline $\begin{array}{l}\text { 2. I enjoy talking to my friends } \\
\text { and/or family about what } \\
\text { I'm doing for my class } \\
\text { ecology project. }\end{array}$ & $\begin{array}{l}\text { Definitely } \\
\text { NOT true for } \\
\text { me }\end{array}$ & $\begin{array}{l}\text { True for me } \\
\text { once in a } \\
\text { while }\end{array}$ & $\begin{array}{l}\text { Sometimes } \\
\text { true for me }\end{array}$ & $\begin{array}{l}\text { Definitely } \\
\text { TRUE for } \\
\text { me }\end{array}$ \\
\hline $\begin{array}{l}\text { 3. I enjoy learning about } \\
\text { environmental science by } \\
\text { going outdoors. }\end{array}$ & $\begin{array}{l}\text { Definitely } \\
\text { NOT true for } \\
\text { me }\end{array}$ & $\begin{array}{l}\text { True for me } \\
\text { once in a } \\
\text { while }\end{array}$ & $\begin{array}{l}\text { Sometimes } \\
\text { true for me }\end{array}$ & $\begin{array}{l}\text { Definitely } \\
\text { TRUE for } \\
\text { me }\end{array}$ \\
\hline $\begin{array}{l}\text { 4. I feel that natural areas, like } \\
\text { where we work for our } \\
\text { science class project, are } \\
\text { important. }\end{array}$ & $\begin{array}{l}\text { Definitely } \\
\text { NOT true for } \\
\text { me }\end{array}$ & $\begin{array}{l}\text { True for me } \\
\text { once in a } \\
\text { while }\end{array}$ & $\begin{array}{l}\text { Sometimes } \\
\text { true for me }\end{array}$ & $\begin{array}{l}\text { Definitely } \\
\text { TRUE for } \\
\text { me }\end{array}$ \\
\hline $\begin{array}{l}\text { 5. I feel like I am making a } \\
\text { meaningful contribution to } \\
\text { the environment through our } \\
\text { class ecology project. }\end{array}$ & $\begin{array}{l}\text { Definitely } \\
\text { NOT true for } \\
\text { me }\end{array}$ & $\begin{array}{l}\text { True for me } \\
\text { once in a } \\
\text { while }\end{array}$ & $\begin{array}{l}\text { Sometimes } \\
\text { true for me }\end{array}$ & $\begin{array}{l}\text { Definitely } \\
\text { TRUE for } \\
\text { me }\end{array}$ \\
\hline $\begin{array}{l}\text { 6. I would like to help (or have } \\
\text { already helped) create } \\
\text { natural areas/landscapes at } \\
\text { our home. }\end{array}$ & $\begin{array}{l}\text { Definitely } \\
\text { NOT true for } \\
\text { me }\end{array}$ & $\begin{array}{l}\text { True for me } \\
\text { once in a } \\
\text { while }\end{array}$ & $\begin{array}{l}\text { Sometimes } \\
\text { true for me }\end{array}$ & $\begin{array}{l}\text { Definitely } \\
\text { TRUE for } \\
\text { me }\end{array}$ \\
\hline $\begin{array}{l}\text { 7. I would be upset if the area } \\
\text { where we work in our } \\
\text { ecology project were to be } \\
\text { destroyed. }\end{array}$ & $\begin{array}{l}\text { Definitely } \\
\text { NOT true for } \\
\text { me }\end{array}$ & $\begin{array}{l}\text { True for me } \\
\text { once in a } \\
\text { while }\end{array}$ & $\begin{array}{l}\text { Sometimes } \\
\text { true for me }\end{array}$ & $\begin{array}{l}\text { Definitely } \\
\text { TRUE for } \\
\text { me }\end{array}$ \\
\hline $\begin{array}{l}\text { 8. I think you can get along } \\
\text { perfectly well in everyday } \\
\text { life without the natural } \\
\text { environment. }\end{array}$ & $\begin{array}{l}\text { Definitely } \\
\text { NOT true for } \\
\text { me }\end{array}$ & $\begin{array}{l}\text { True for me } \\
\text { once in a } \\
\text { while }\end{array}$ & $\begin{array}{l}\text { Sometimes } \\
\text { true for me }\end{array}$ & $\begin{array}{l}\text { Definitely } \\
\text { TRUE for } \\
\text { me }\end{array}$ \\
\hline $\begin{array}{l}\text { 9. I would like to continue to } \\
\text { help protect the natural area } \\
\text { where I worked for our class } \\
\text { project. }\end{array}$ & $\begin{array}{l}\text { Definitely } \\
\text { NOT true for } \\
\text { me }\end{array}$ & $\begin{array}{l}\text { True for me } \\
\text { once in a } \\
\text { while }\end{array}$ & $\begin{array}{l}\text { Sometimes } \\
\text { true for me }\end{array}$ & $\begin{array}{l}\text { Definitely } \\
\text { TRUE for } \\
\text { me }\end{array}$ \\
\hline $\begin{array}{l}\text { 10. If I had to move away, I } \\
\text { would miss the natural area } \\
\text { where I worked. }\end{array}$ & $\begin{array}{l}\text { Definitely } \\
\text { NOT true for } \\
\text { me }\end{array}$ & $\begin{array}{l}\text { True for me } \\
\text { once in a } \\
\text { while }\end{array}$ & $\begin{array}{l}\text { Sometimes } \\
\text { true for me }\end{array}$ & $\begin{array}{l}\text { Definitely } \\
\text { TRUE for } \\
\text { me }\end{array}$ \\
\hline
\end{tabular}




\begin{tabular}{|c|c|c|c|c|}
\hline $\begin{array}{l}\text { 11. I would like to continue to } \\
\text { do restoration work in } \\
\text { Forest Park or another local } \\
\text { natural area. }\end{array}$ & $\begin{array}{l}\text { Definitely } \\
\text { NOT true for } \\
\text { me }\end{array}$ & $\begin{array}{l}\text { True for me } \\
\text { once in a } \\
\text { while }\end{array}$ & $\begin{array}{l}\text { Sometimes } \\
\text { true for me }\end{array}$ & $\begin{array}{l}\text { Definitely } \\
\text { TRUE for } \\
\text { me }\end{array}$ \\
\hline $\begin{array}{l}\text { 12. I would like to help protect } \\
\text { natural areas in other parts } \\
\text { of the country. }\end{array}$ & $\begin{array}{l}\text { Definitely } \\
\text { NOT true for } \\
\text { me }\end{array}$ & $\begin{array}{l}\text { True for me } \\
\text { once in a } \\
\text { while }\end{array}$ & $\begin{array}{l}\text { Sometimes } \\
\text { true for me }\end{array}$ & $\begin{array}{l}\text { Definitely } \\
\text { TRUE for } \\
\text { me }\end{array}$ \\
\hline $\begin{array}{l}\text { 13. I think I would bring family } \\
\text { and friends to the natural } \\
\text { area where I worked to } \\
\text { show them around. }\end{array}$ & $\begin{array}{l}\text { Definitely } \\
\text { NOT true for } \\
\text { me }\end{array}$ & $\begin{array}{l}\text { True for me } \\
\text { once in a } \\
\text { while }\end{array}$ & $\begin{array}{l}\text { Sometimes } \\
\text { true for me }\end{array}$ & $\begin{array}{l}\text { Definitely } \\
\text { TRUE for } \\
\text { me }\end{array}$ \\
\hline $\begin{array}{l}\text { 14. I feel a strong emotional } \\
\text { connection to natural areas.. }\end{array}$ & $\begin{array}{l}\text { Definitely } \\
\text { NOT true for } \\
\text { me }\end{array}$ & $\begin{array}{l}\text { True for me } \\
\text { once in a } \\
\text { while }\end{array}$ & $\begin{array}{l}\text { Sometimes } \\
\text { true for me }\end{array}$ & $\begin{array}{l}\text { Definitely } \\
\text { TRUE for } \\
\text { me }\end{array}$ \\
\hline $\begin{array}{l}\text { 15. I like to learn about natural } \\
\text { ecosystems, the plants and } \\
\text { animals that live in them. }\end{array}$ & $\begin{array}{l}\text { Definitely } \\
\text { NOT true for } \\
\text { me }\end{array}$ & $\begin{array}{l}\text { True for me } \\
\text { once in a } \\
\text { while }\end{array}$ & $\begin{array}{l}\text { Sometimes } \\
\text { true for me }\end{array}$ & $\begin{array}{l}\text { Definitely } \\
\text { TRUE for } \\
\text { me }\end{array}$ \\
\hline
\end{tabular}




\section{Appendix A.3: Science Interest Survey (Year One) \\ Science Interest Survey}

Teacher's name:

Grade

School:

Check whether you are: A boy ___ or a girl

Do you speak Spanish at home: $\overline{Y E S}$ _ NO

We're interesting in finding out what you think about science. Read each statement, and then circle the response that best describes how true the statement is for you.

\begin{tabular}{|c|c|c|c|}
\hline 1. I think science at school is boring. & $\begin{array}{l}\text { Definitely } \\
\text { NOT true for } \\
\text { me }\end{array}$ & $\begin{array}{l}\text { Sometimes } \\
\text { true for me }\end{array}$ & $\begin{array}{l}\text { Definitely } \\
\text { TRUE for me }\end{array}$ \\
\hline $\begin{array}{l}\text { 2. I enjoy talking to my friends and family } \\
\text { about what I'm learning in my life science } \\
\text { class. }\end{array}$ & $\begin{array}{l}\text { Definitely } \\
\text { NOT true for } \\
\text { me }\end{array}$ & $\begin{array}{l}\text { Sometimes } \\
\text { true for me }\end{array}$ & $\begin{array}{l}\text { Definitely } \\
\text { TRUE for me }\end{array}$ \\
\hline $\begin{array}{l}\text { 3. I enjoy learning about science by going } \\
\text { outdoors. }\end{array}$ & $\begin{array}{l}\text { Definitely } \\
\text { NOT true for } \\
\text { me }\end{array}$ & $\begin{array}{l}\text { Sometimes } \\
\text { true for me }\end{array}$ & $\begin{array}{l}\text { Definitely } \\
\text { TRUE for me }\end{array}$ \\
\hline $\begin{array}{l}\text { 4. I think that working as a scientist would be } \\
\text { an interesting way to earn a living. }\end{array}$ & $\begin{array}{l}\text { Definitely } \\
\text { NOT true for } \\
\text { me }\end{array}$ & $\begin{array}{l}\text { Sometimes } \\
\text { true for me }\end{array}$ & $\begin{array}{l}\text { Definitely } \\
\text { TRUE for me }\end{array}$ \\
\hline $\begin{array}{l}\text { 5. When I go to college, I plan to major in } \\
\text { science. }\end{array}$ & $\begin{array}{l}\text { Definitely } \\
\text { NOT true for } \\
\text { me }\end{array}$ & $\begin{array}{l}\text { Sometimes } \\
\text { true for me }\end{array}$ & $\begin{array}{l}\text { Definitely } \\
\text { TRUE for me }\end{array}$ \\
\hline $\begin{array}{l}\text { 6. I have become more aware of the } \\
\text { environment because of my science } \\
\text { lessons. }\end{array}$ & $\begin{array}{l}\text { Definitely } \\
\text { NOT true for } \\
\text { me }\end{array}$ & $\begin{array}{l}\text { Sometimes } \\
\text { true for me }\end{array}$ & $\begin{array}{l}\text { Definitely } \\
\text { TRUE for me }\end{array}$ \\
\hline $\begin{array}{l}\text { 7. I think the Spanish translations of student } \\
\text { material is helpful for me. }\end{array}$ & $\begin{array}{l}\text { Definitely } \\
\text { NOT true for } \\
\text { me }\end{array}$ & $\begin{array}{l}\text { Sometimes } \\
\text { true for me }\end{array}$ & $\begin{array}{l}\text { Definitely } \\
\text { TRUE for me }\end{array}$ \\
\hline $\begin{array}{l}\text { 8. I think you can get along perfectly well in } \\
\text { everyday life without science. }\end{array}$ & $\begin{array}{l}\text { Definitely } \\
\text { NOT true for } \\
\text { me }\end{array}$ & $\begin{array}{l}\text { Sometimes } \\
\text { true for me }\end{array}$ & $\begin{array}{l}\text { Definitely } \\
\text { TRUE for me }\end{array}$ \\
\hline $\begin{array}{l}\text { 9. I think it's important to study the local } \\
\text { animals and plants and their relationships }\end{array}$ & $\begin{array}{l}\text { Definitely } \\
\text { NOT true for } \\
\text { me }\end{array}$ & $\begin{array}{l}\text { Sometimes } \\
\text { true for me }\end{array}$ & $\begin{array}{l}\text { Definitely } \\
\text { TRUE for me }\end{array}$ \\
\hline $\begin{array}{l}\text { 10. I would rather be given the right answer to } \\
\text { a science problem than to work it out } \\
\text { myself. }\end{array}$ & $\begin{array}{l}\text { Definitely } \\
\text { NOT true for } \\
\text { me }\end{array}$ & $\begin{array}{l}\text { Sometimes } \\
\text { true for me }\end{array}$ & $\begin{array}{l}\text { Definitely } \\
\text { TRUE for me }\end{array}$ \\
\hline $\begin{array}{l}\text { 11. I believe you can learn science in lots of } \\
\text { places, not only laboratories or classrooms. }\end{array}$ & $\begin{array}{l}\text { Definitely } \\
\text { NOT true for } \\
\text { me }\end{array}$ & $\begin{array}{l}\text { Sometimes } \\
\text { true for me }\end{array}$ & $\begin{array}{l}\text { Definitely } \\
\text { TRUE for me }\end{array}$ \\
\hline $\begin{array}{l}\text { 12. I am more curious about the plants, } \\
\text { animals, earth and universe where I live } \\
\text { because of my science lessons. }\end{array}$ & $\begin{array}{l}\text { Definitely } \\
\text { NOT true for } \\
\text { me }\end{array}$ & $\begin{array}{l}\text { Sometimes } \\
\text { true for me }\end{array}$ & $\begin{array}{l}\text { Definitely } \\
\text { TRUE for me }\end{array}$ \\
\hline 13. I believe that what is known about a & Definitely & Sometimes & Definitely \\
\hline
\end{tabular}




\begin{tabular}{|l|c|c|c|}
\hline $\begin{array}{l}\text { scientific field like ecology changes as } \\
\text { scientists come up with new ideas from } \\
\text { their experiments. }\end{array}$ & $\begin{array}{c}\text { NOT true for } \\
\text { me }\end{array}$ & true for me & TRUE for me \\
\hline $\begin{array}{l}\text { 14. I like trying to find the answers to } \\
\text { scientific questions by doing experiments, } \\
\text { collecting data, and interpreting the } \\
\text { meaning of the data. }\end{array}$ & $\begin{array}{c}\text { Definitely } \\
\text { NOT true for } \\
\text { me }\end{array}$ & $\begin{array}{c}\text { Sometimes } \\
\text { true for me }\end{array}$ & $\begin{array}{c}\text { Definitely } \\
\text { TRUE for me }\end{array}$ \\
\hline $\begin{array}{l}\text { 15. I enjoy learning science from guests who } \\
\text { visit our classroom and help our teacher } \\
\text { with science lessons }\end{array}$ & $\begin{array}{c}\text { Definitely } \\
\text { NOT true for } \\
\text { me }\end{array}$ & $\begin{array}{l}\text { Sometimes } \\
\text { true for me }\end{array}$ & $\begin{array}{c}\text { Definitely } \\
\text { TRUE for me }\end{array}$ \\
\hline
\end{tabular}




\section{Appendix A.4: 30-Question Pre-Stewardship Survey (Year Two) Stewardship Survey Pre}

Name: Check whether you are: Male

Female Grade: Have you ever helped to restore or conduct research in a natural area before this class?

YES Describe:

$\mathrm{NO}$

We're interesting in finding out what you think about stewardship projects. Read each statement, and then circle the response that best describes how true the statement is for you.

\begin{tabular}{|c|c|c|c|c|c|}
\hline $\begin{array}{l}\text { I. I go outdoors to natural } \\
\text { environments in my free time } \\
\text { whenever I can. }\end{array}$ & $\begin{array}{l}\text { Definitely } \\
\text { NOT true } \\
\text { for me }\end{array}$ & I might & Sometimes & Often & $\begin{array}{l}\text { Definitely } \\
\text { true for } \\
\text { me }\end{array}$ \\
\hline $\begin{array}{l}\text { 2. I enjoy talking to my friends } \\
\text { and family about what I'm } \\
\text { doing in science class. }\end{array}$ & $\begin{array}{l}\text { Definitely } \\
\text { NOT true } \\
\text { for me }\end{array}$ & I might & Sometimes & Often & $\begin{array}{l}\text { Definitely } \\
\text { true for } \\
\text { me }\end{array}$ \\
\hline $\begin{array}{l}\text { 3. I don't really like finding } \\
\text { signs of animals or learning } \\
\text { about the plants, while I am } \\
\text { outdoors. }\end{array}$ & $\begin{array}{l}\text { Definitely } \\
\text { NOT true } \\
\text { for me }\end{array}$ & I might & Sometimes & Often & $\begin{array}{l}\text { Definitely } \\
\text { true for } \\
\text { me }\end{array}$ \\
\hline $\begin{array}{l}\text { 4. I feel a strong attachment to } \\
\text { particular natural places. }\end{array}$ & $\begin{array}{l}\text { Definitely } \\
\text { NOT true } \\
\text { for me }\end{array}$ & I might & Sometimes & Often & $\begin{array}{l}\text { Definitely } \\
\text { true for } \\
\text { me }\end{array}$ \\
\hline $\begin{array}{l}\text { 5. I think that I am going to } \\
\text { help the environment through } \\
\text { our project in science class. }\end{array}$ & $\begin{array}{l}\text { Definitely } \\
\text { NOT true } \\
\text { for me }\end{array}$ & I might & Sometimes & Often & $\begin{array}{l}\text { Definitely } \\
\text { true for } \\
\text { me }\end{array}$ \\
\hline $\begin{array}{l}\text { 6. I would like to help restore or } \\
\text { study natural areas in my } \\
\text { community. }\end{array}$ & $\begin{array}{l}\text { Definitely } \\
\text { NOT true } \\
\text { for me }\end{array}$ & I might & Sometimes & Often & $\begin{array}{l}\text { Definitely } \\
\text { true for } \\
\text { me }\end{array}$ \\
\hline $\begin{array}{l}\text { 7. I would not give } \$ 15 \text { of my } \\
\text { own money to help the } \\
\text { environment. }\end{array}$ & $\begin{array}{l}\text { Definitely } \\
\text { NOT true } \\
\text { for me }\end{array}$ & I might & Sometimes & Often & $\begin{array}{l}\text { Definitely } \\
\text { true for } \\
\text { me }\end{array}$ \\
\hline $\begin{array}{l}\text { 8. I think you can get along fine } \\
\text { without spending time in } \\
\text { nature. }\end{array}$ & $\begin{array}{l}\text { Definitely } \\
\text { NOT true } \\
\text { for me }\end{array}$ & I might & Sometimes & Often & $\begin{array}{l}\text { Definitely } \\
\text { true for } \\
\text { me }\end{array}$ \\
\hline $\begin{array}{l}\text { 9. I think people can do } \\
\text { something helpful for the } \\
\text { natural world. }\end{array}$ & $\begin{array}{l}\text { Definitely } \\
\text { NOT true } \\
\text { for me }\end{array}$ & I might & Sometimes & Often & $\begin{array}{l}\text { Definitely } \\
\text { true for } \\
\text { me }\end{array}$ \\
\hline $\begin{array}{l}\text { 10. If I had to move away, I } \\
\text { would miss the natural areas } \\
\text { where I have visited with my } \\
\text { class. }\end{array}$ & $\begin{array}{l}\text { Definitely } \\
\text { NOT true } \\
\text { for me }\end{array}$ & I might & Sometimes & Often & $\begin{array}{l}\text { Definitely } \\
\text { true for } \\
\text { me }\end{array}$ \\
\hline $\begin{array}{l}\text { 11. I think it will be fun to } \\
\text { collect data in a natural area. }\end{array}$ & $\begin{array}{l}\text { Definitely } \\
\text { NOT true }\end{array}$ & I might & Sometimes & Often & $\begin{array}{l}\text { Definitely } \\
\text { true for }\end{array}$ \\
\hline
\end{tabular}




\begin{tabular}{|c|c|c|c|c|c|}
\hline & for me & & & & me \\
\hline $\begin{array}{l}\text { 12. I think my work in natural } \\
\text { areas is doing something } \\
\text { useful. }\end{array}$ & $\begin{array}{l}\text { Definitely } \\
\text { NOT true } \\
\text { for me }\end{array}$ & I might & Sometimes & Often & $\begin{array}{l}\text { Definitely } \\
\text { true for } \\
\text { me }\end{array}$ \\
\hline $\begin{array}{l}\text { 13. I would show the natural area } \\
\text { where I worked to my friends } \\
\text { and/or family, if I have a } \\
\text { chance. }\end{array}$ & $\begin{array}{l}\text { Definitely } \\
\text { NOT true } \\
\text { for me }\end{array}$ & I might & Sometimes & Often & $\begin{array}{l}\text { Definitely } \\
\text { true for } \\
\text { me }\end{array}$ \\
\hline $\begin{array}{l}\text { 14. I think that by collecting } \\
\text { data, better management } \\
\text { decisions about a natural area } \\
\text { can be made. }\end{array}$ & $\begin{array}{l}\text { Definitely } \\
\text { NOT true } \\
\text { for me }\end{array}$ & I might & Sometimes & Often & $\begin{array}{l}\text { Definitely } \\
\text { true for } \\
\text { me }\end{array}$ \\
\hline $\begin{array}{l}\text { 15. I like to learn about natural } \\
\text { ecosystems, the plants and } \\
\text { animals that live in them. }\end{array}$ & $\begin{array}{l}\text { Definitely } \\
\text { NOT true } \\
\text { for me }\end{array}$ & I might & Sometimes & Often & $\begin{array}{l}\text { Definitely } \\
\text { true for } \\
\text { me }\end{array}$ \\
\hline $\begin{array}{l}\text { 16. I like the chance to be } \\
\text { outdoors. }\end{array}$ & $\begin{array}{l}\text { Definitely } \\
\text { NOT true } \\
\text { for me }\end{array}$ & I might & Sometimes & Often & $\begin{array}{l}\text { Definitely } \\
\text { true for } \\
\text { me }\end{array}$ \\
\hline $\begin{array}{l}\text { 17. I can recognize unhealthy } \\
\text { landscapes (like ones with } \\
\text { invasive species). }\end{array}$ & $\begin{array}{l}\text { Definitely } \\
\text { NOT true } \\
\text { for me }\end{array}$ & I might & Sometimes & Often & $\begin{array}{l}\text { Definitely } \\
\text { true for } \\
\text { me }\end{array}$ \\
\hline $\begin{array}{l}\text { 18. I am more aware of my } \\
\text { impacts to the natural } \\
\text { environment (than before). }\end{array}$ & $\begin{array}{l}\text { Definitely } \\
\text { NOT true } \\
\text { for me }\end{array}$ & I might & Sometimes & Often & $\begin{array}{l}\text { Definitely } \\
\text { true for } \\
\text { me }\end{array}$ \\
\hline $\begin{array}{l}\text { 19. I get upset when I learn about } \\
\text { the destruction of natural } \\
\text { areas, even if they are far } \\
\text { away. }\end{array}$ & $\begin{array}{l}\text { Definitely } \\
\text { NOT true } \\
\text { for me }\end{array}$ & I might & Sometimes & Often & $\begin{array}{l}\text { Definitely } \\
\text { true for } \\
\text { me }\end{array}$ \\
\hline $\begin{array}{l}\text { 20. I try to seek out more } \\
\text { information about the natural } \\
\text { world whenever I can. }\end{array}$ & $\begin{array}{l}\text { Definitely } \\
\text { NOT true } \\
\text { for me }\end{array}$ & I might & Sometimes & Often & $\begin{array}{l}\text { Definitely } \\
\text { true for } \\
\text { me }\end{array}$ \\
\hline $\begin{array}{l}\text { 21. I write letters to elected } \\
\text { officials about environmental } \\
\text { issues. }\end{array}$ & $\begin{array}{l}\text { Definitely } \\
\text { NOT true } \\
\text { for me }\end{array}$ & I might & Sometimes & Often & $\begin{array}{l}\text { Definitely } \\
\text { true for } \\
\text { me }\end{array}$ \\
\hline $\begin{array}{l}\text { 22. I have encouraged my family } \\
\text { to change their energy use. }\end{array}$ & $\begin{array}{l}\text { Definitely } \\
\text { NOT true } \\
\text { for me }\end{array}$ & I might & Sometimes & Often & $\begin{array}{l}\text { Definitely } \\
\text { true for } \\
\text { me }\end{array}$ \\
\hline $\begin{array}{l}\text { 23. When I am on a trail, I try not } \\
\text { to go off trail. }\end{array}$ & $\begin{array}{l}\text { Definitely } \\
\text { NOT true } \\
\text { for me }\end{array}$ & I might & Sometimes & Often & $\begin{array}{l}\text { Definitely } \\
\text { true for } \\
\text { me }\end{array}$ \\
\hline $\begin{array}{l}\text { 24. I feel at home when I am in } \\
\text { natural areas. }\end{array}$ & $\begin{array}{l}\text { Definitely } \\
\text { NOT true } \\
\text { for me }\end{array}$ & I might & Sometimes & Often & $\begin{array}{l}\text { Definitely } \\
\text { true for } \\
\text { me }\end{array}$ \\
\hline
\end{tabular}




\begin{tabular}{|l|l|l|l|l|c|}
\hline $\begin{array}{l}\text { 25. People are often surprised } \\
\text { about how many species I } \\
\text { can identify in natural areas. }\end{array}$ & $\begin{array}{c}\text { Definitely } \\
\text { NOT true } \\
\text { for me }\end{array}$ & I might & Sometimes & Often & $\begin{array}{c}\text { Definitely } \\
\text { true for } \\
\text { me }\end{array}$ \\
\hline $\begin{array}{l}\text { 26. I enjoy observing things in } \\
\text { nature. }\end{array}$ & $\begin{array}{c}\text { Definitely } \\
\text { NOT true } \\
\text { for me }\end{array}$ & I might & Sometimes & Often & $\begin{array}{c}\text { Definitely } \\
\text { true for } \\
\text { me }\end{array}$ \\
\hline $\begin{array}{l}\text { 27. I think my work in natural } \\
\text { areas will result in } \\
\text { improvements in } \\
\text { environmental conditions. }\end{array}$ & $\begin{array}{c}\text { Definitely } \\
\text { NOT true } \\
\text { for me }\end{array}$ & I might & Sometimes & Often & $\begin{array}{c}\text { Definitely } \\
\text { true for } \\
\text { me }\end{array}$ \\
\hline $\begin{array}{l}\text { 28. I like the feeling of doing } \\
\text { something useful. }\end{array}$ & $\begin{array}{c}\text { Definitely } \\
\text { NOT true } \\
\text { for me }\end{array}$ & I might & Sometimes & Often & $\begin{array}{c}\text { Definitely } \\
\text { true for } \\
\text { me }\end{array}$ \\
\hline $\begin{array}{l}\text { 29. I actively advocate for } \\
\text { conservation by talking to } \\
\text { others. }\end{array}$ & $\begin{array}{c}\text { Definitely } \\
\text { NOT true } \\
\text { for me }\end{array}$ & I might & Sometimes & Often & $\begin{array}{c}\text { Definitely } \\
\text { true for } \\
\text { me }\end{array}$ \\
\hline $\begin{array}{l}\text { 30. I am concerned about present } \\
\text { conditions in Forest Park and } \\
\text { about how it can be } \\
\text { preserved. }\end{array}$ & $\begin{array}{l}\text { Definitely } \\
\text { NOT true } \\
\text { for me }\end{array}$ & I might & Sometimes & Often & $\begin{array}{c}\text { Definitely } \\
\text { true for } \\
\text { me }\end{array}$ \\
\hline
\end{tabular}




\section{Appendix A.5: 30-Question Post-Stewardship Survey (Year Two) Stewardship Survey Post}

Teacher's Name:

Grade: Check whether you are: Male

Female

Have you ever helped to restore or conduct research in a natural area?

YES Describe:

$\mathrm{NO}$

We're interested in finding out what you think about stewardship projects. Read each statement, and then circle the response that best describes how true the statement is for you.

\begin{tabular}{|c|c|c|c|c|c|}
\hline $\begin{array}{l}\text { I. I go outdoors to natural } \\
\text { environments in my free time } \\
\text { more than before. }\end{array}$ & $\begin{array}{l}\text { Definitely } \\
\text { NOT true } \\
\text { for me }\end{array}$ & I might & Sometimes & Often & $\begin{array}{l}\text { Definitely } \\
\text { true for } \\
\text { me }\end{array}$ \\
\hline $\begin{array}{l}\text { 2. I enjoy talking to my friends } \\
\text { and family about what I'm } \\
\text { doing in science class. }\end{array}$ & $\begin{array}{l}\text { Definitely } \\
\text { NOT true } \\
\text { for me }\end{array}$ & I might & Sometimes & Often & $\begin{array}{l}\text { Definitely } \\
\text { true for } \\
\text { me }\end{array}$ \\
\hline $\begin{array}{l}\text { 3. I don't really like finding } \\
\text { signs of animals or learning } \\
\text { about the plants, while I am } \\
\text { outdoors. }\end{array}$ & $\begin{array}{l}\text { Definitely } \\
\text { NOT true } \\
\text { for me }\end{array}$ & I might & Sometimes & Often & $\begin{array}{l}\text { Definitely } \\
\text { true for } \\
\text { me }\end{array}$ \\
\hline $\begin{array}{l}\text { 4. I feel a strong attachment to } \\
\text { particular natural places more } \\
\text { than before. }\end{array}$ & $\begin{array}{l}\text { Definitely } \\
\text { NOT true } \\
\text { for me }\end{array}$ & I might & Sometimes & Often & $\begin{array}{l}\text { Definitely } \\
\text { true for } \\
\text { me }\end{array}$ \\
\hline $\begin{array}{l}\text { 5. I think that I helped the } \\
\text { environment through our } \\
\text { project in science class. }\end{array}$ & $\begin{array}{l}\text { Definitely } \\
\text { NOT true } \\
\text { for me }\end{array}$ & I might & Sometimes & Often & $\begin{array}{l}\text { Definitely } \\
\text { true for } \\
\text { me }\end{array}$ \\
\hline $\begin{array}{l}\text { 6. I like to help restore or study } \\
\text { natural areas in my } \\
\text { community. }\end{array}$ & $\begin{array}{l}\text { Definitely } \\
\text { NOT true } \\
\text { for me }\end{array}$ & I might & Sometimes & Often & $\begin{array}{l}\text { Definitely } \\
\text { true for } \\
\text { me }\end{array}$ \\
\hline $\begin{array}{l}\text { 7. I would not give } \$ 15 \text { of my } \\
\text { own money to help the } \\
\text { environment. }\end{array}$ & $\begin{array}{l}\text { Definitely } \\
\text { NOT true } \\
\text { for me }\end{array}$ & I might & Sometimes & Often & $\begin{array}{l}\text { Definitely } \\
\text { true for } \\
\text { me }\end{array}$ \\
\hline $\begin{array}{l}\text { 8. I think you can get along fine } \\
\text { without spending time in } \\
\text { nature. }\end{array}$ & $\begin{array}{l}\text { Definitely } \\
\text { NOT true } \\
\text { for me }\end{array}$ & I might & Sometimes & Often & $\begin{array}{l}\text { Definitely } \\
\text { true for } \\
\text { me }\end{array}$ \\
\hline $\begin{array}{l}\text { 9. I think people can do } \\
\text { something helpful for the } \\
\text { natural world. }\end{array}$ & $\begin{array}{l}\text { Definitely } \\
\text { NOT true } \\
\text { for me }\end{array}$ & I might & Sometimes & Often & $\begin{array}{l}\text { Definitely } \\
\text { true for } \\
\text { me }\end{array}$ \\
\hline $\begin{array}{l}\text { 10. If I had to move away, I } \\
\text { would miss the natural areas } \\
\text { at my school. }\end{array}$ & $\begin{array}{l}\text { Definitely } \\
\text { NOT true } \\
\text { for me }\end{array}$ & I might & Sometimes & Often & $\begin{array}{l}\text { Definitely } \\
\text { true for } \\
\text { me }\end{array}$ \\
\hline $\begin{array}{l}\text { 11. I think it is fun to collect data } \\
\text { in a natural area. }\end{array}$ & $\begin{array}{l}\text { Definitely } \\
\text { NOT true } \\
\text { for me }\end{array}$ & I might & Sometimes & Often & $\begin{array}{l}\text { Definitely } \\
\text { true for } \\
\text { me }\end{array}$ \\
\hline
\end{tabular}




\begin{tabular}{|c|c|c|c|c|c|}
\hline $\begin{array}{l}\text { 12. I think my work in natural } \\
\text { areas is doing something } \\
\text { useful. }\end{array}$ & $\begin{array}{l}\text { Definitely } \\
\text { NOT true } \\
\text { for me }\end{array}$ & I might & Sometimes & Often & $\begin{array}{l}\text { Definitely } \\
\text { true for } \\
\text { me }\end{array}$ \\
\hline $\begin{array}{l}\text { 13. I would show the natural area } \\
\text { at my school to my friends } \\
\text { and/or family, if I have a } \\
\text { chance. }\end{array}$ & $\begin{array}{l}\text { Definitely } \\
\text { NOT true } \\
\text { for me }\end{array}$ & I might & Sometimes & Often & $\begin{array}{l}\text { Definitely } \\
\text { true for } \\
\text { me }\end{array}$ \\
\hline $\begin{array}{l}\text { 14. I think that by collecting } \\
\text { data, better management } \\
\text { decisions about a natural area } \\
\text { can be made. }\end{array}$ & $\begin{array}{l}\text { Definitely } \\
\text { NOT true } \\
\text { for me }\end{array}$ & I might & Sometimes & Often & $\begin{array}{l}\text { Definitely } \\
\text { true for } \\
\text { me }\end{array}$ \\
\hline $\begin{array}{l}\text { 15. I like to learn about natural } \\
\text { ecosystems and the plants } \\
\text { and animals that live in them. }\end{array}$ & $\begin{array}{l}\text { Definitely } \\
\text { NOT true } \\
\text { for me }\end{array}$ & I might & Sometimes & Often & $\begin{array}{l}\text { Definitely } \\
\text { true for } \\
\text { me }\end{array}$ \\
\hline 16. I li & $\begin{array}{l}\text { Definitely } \\
\text { NOT true } \\
\text { for me }\end{array}$ & I might & Sometimes & Often & $\begin{array}{l}\text { Definitely } \\
\text { true for } \\
\text { me }\end{array}$ \\
\hline $\begin{array}{l}\text { 17. I can recognize unhealthy } \\
\text { landscapes (like ones with } \\
\text { invasive species). }\end{array}$ & $\begin{array}{l}\text { Definitely } \\
\text { NOT true } \\
\text { for me }\end{array}$ & I might & Sometimes & Often & $\begin{array}{l}\text { Definitely } \\
\text { true for } \\
\text { me }\end{array}$ \\
\hline $\begin{array}{l}\text { 18. I am more aware of my } \\
\text { impacts to the natural } \\
\text { environment than before. }\end{array}$ & $\begin{array}{l}\text { Definitely } \\
\text { NOT true } \\
\text { for me }\end{array}$ & I might & Sometimes & Often & $\begin{array}{l}\text { Definitely } \\
\text { true for } \\
\text { me }\end{array}$ \\
\hline $\begin{array}{l}\text { 19. I get upset when I learn about } \\
\text { the destruction of natural } \\
\text { areas, even if they are far } \\
\text { away. }\end{array}$ & $\begin{array}{l}\text { Definitely } \\
\text { NOT true } \\
\text { for me }\end{array}$ & I might & Sometimes & Often & $\begin{array}{l}\text { Definitely } \\
\text { true for } \\
\text { me }\end{array}$ \\
\hline $\begin{array}{l}\text { 20. I try to seek out more } \\
\text { information about the natural } \\
\text { world whenever I can. }\end{array}$ & $\begin{array}{l}\text { Definitely } \\
\text { NOT true } \\
\text { for me }\end{array}$ & I might & Sometimes & Often & $\begin{array}{l}\text { Definitely } \\
\text { true for } \\
\text { me }\end{array}$ \\
\hline $\begin{array}{l}\text { 21. I write letters to elected } \\
\text { officials about environmental } \\
\text { issues more than before. }\end{array}$ & $\begin{array}{l}\text { Definitely } \\
\text { NOT true } \\
\text { for me }\end{array}$ & I might & Sometimes & Often & $\begin{array}{l}\text { Definitely } \\
\text { true for } \\
\text { me }\end{array}$ \\
\hline $\begin{array}{l}\text { 22. I have encouraged my family } \\
\text { to change their energy use. }\end{array}$ & $\begin{array}{l}\text { Definitely } \\
\text { NOT true } \\
\text { for me }\end{array}$ & I might & Sometimes & Often & $\begin{array}{l}\text { Definitely } \\
\text { true for } \\
\text { me }\end{array}$ \\
\hline $\begin{array}{l}\text { 23. When I am on a trail, I try not } \\
\text { to go off trail. }\end{array}$ & $\begin{array}{l}\text { Definitely } \\
\text { NOT true } \\
\text { for me }\end{array}$ & I might & Sometimes & Often & $\begin{array}{l}\text { Definitely } \\
\text { true for } \\
\text { me }\end{array}$ \\
\hline $\begin{array}{l}\text { 24. I feel at home when I am in } \\
\text { natural areas. }\end{array}$ & $\begin{array}{l}\text { Definitely } \\
\text { NOT true } \\
\text { for me }\end{array}$ & I might & Sometimes & Often & $\begin{array}{l}\text { Definitely } \\
\text { true for } \\
\text { me }\end{array}$ \\
\hline
\end{tabular}




\begin{tabular}{|l|c|l|l|l|c|}
\hline $\begin{array}{l}\text { 25. People are often surprised } \\
\text { about how many species I } \\
\text { can identify in natural areas. }\end{array}$ & $\begin{array}{c}\text { Definitely } \\
\text { NOT true } \\
\text { for me }\end{array}$ & I might & Sometimes & Often & $\begin{array}{c}\text { Definitely } \\
\text { true for } \\
\text { me }\end{array}$ \\
\hline $\begin{array}{l}\text { 26. I enjoy observing things in } \\
\text { nature. }\end{array}$ & $\begin{array}{c}\text { Definitely } \\
\text { NOT true } \\
\text { for me }\end{array}$ & I might & Sometimes & Often & $\begin{array}{c}\text { Definitely } \\
\text { true for } \\
\text { me }\end{array}$ \\
\hline $\begin{array}{l}\text { 27. I think my work in natural } \\
\text { areas will result in } \\
\text { improvements in } \\
\text { environmental conditions. }\end{array}$ & $\begin{array}{c}\text { Definitely } \\
\text { NOT true } \\
\text { for me }\end{array}$ & I might & Sometimes & Often & $\begin{array}{c}\text { Definitely } \\
\text { true for } \\
\text { me }\end{array}$ \\
\hline $\begin{array}{l}\text { 28. I like the feeling of doing } \\
\text { something useful. }\end{array}$ & $\begin{array}{l}\text { Definitely } \\
\text { NOT true } \\
\text { for me }\end{array}$ & I might & Sometimes & Often & $\begin{array}{c}\text { Definitely } \\
\text { true for } \\
\text { me }\end{array}$ \\
\hline $\begin{array}{l}\text { 29. I actively advocate for } \\
\text { conservation by talking to } \\
\text { others. }\end{array}$ & $\begin{array}{l}\text { Definitely } \\
\text { NOT true } \\
\text { for me }\end{array}$ & I might & Sometimes & Often & $\begin{array}{c}\text { Definitely } \\
\text { true for } \\
\text { me }\end{array}$ \\
\hline $\begin{array}{l}\text { 30. I am concerned about present } \\
\text { conditions in parks and about } \\
\text { how they can be preserved. }\end{array}$ & $\begin{array}{l}\text { Definitely } \\
\text { NOT true } \\
\text { for me }\end{array}$ & I might & Sometimes & Often & $\begin{array}{c}\text { Definitely } \\
\text { true for } \\
\text { me }\end{array}$ \\
\hline
\end{tabular}




\section{Appendix A.6: Revised Science Interest Survey (Year Two) Science Interest Survey}

Teacher's name:

Grade: School:

Check whether you are: male female

We're interesting in finding out what you think about science. Read each statement, and then circle the response that best describes how true the statement is for you.

\begin{tabular}{|c|c|c|c|c|c|}
\hline $\begin{array}{l}\text { 1. I think science at school is } \\
\text { boring. }\end{array}$ & $\begin{array}{l}\text { Never } \\
\text { true for } \\
\text { me }\end{array}$ & $\begin{array}{l}\text { Sometimes } \\
\text { true for me }\end{array}$ & $\begin{array}{c}\text { Often } \\
\text { true for } \\
\text { me }\end{array}$ & $\begin{array}{c}\text { Usually } \\
\text { true for } \\
\text { me }\end{array}$ & $\begin{array}{c}\text { Always } \\
\text { true for } \\
\text { me }\end{array}$ \\
\hline $\begin{array}{l}\text { 2. I enjoy talking to my friends } \\
\text { and family about what I'm } \\
\text { learning in my life science } \\
\text { class. }\end{array}$ & $\begin{array}{l}\text { Never } \\
\text { true for } \\
\text { me }\end{array}$ & $\begin{array}{l}\text { Sometimes } \\
\text { true for me }\end{array}$ & $\begin{array}{l}\text { Often } \\
\text { true for } \\
\text { me }\end{array}$ & $\begin{array}{l}\text { Usually } \\
\text { true for } \\
\text { me }\end{array}$ & $\begin{array}{c}\text { Always } \\
\text { true for } \\
\text { me }\end{array}$ \\
\hline $\begin{array}{l}\text { 3. I enjoy learning about } \\
\text { science by going outdoors. }\end{array}$ & $\begin{array}{l}\text { Never } \\
\text { true for } \\
\text { me }\end{array}$ & $\begin{array}{l}\text { Sometimes } \\
\text { true for me }\end{array}$ & $\begin{array}{l}\text { Often } \\
\text { true for } \\
\text { me }\end{array}$ & $\begin{array}{c}\text { Usually } \\
\text { true for } \\
\text { me }\end{array}$ & $\begin{array}{c}\text { Always } \\
\text { true for } \\
\text { me }\end{array}$ \\
\hline $\begin{array}{l}\text { 4. I think that working as a } \\
\text { scientist would be an } \\
\text { interesting way to earn a } \\
\text { living. }\end{array}$ & $\begin{array}{l}\text { Never } \\
\text { true for } \\
\text { me }\end{array}$ & $\begin{array}{l}\text { Sometimes } \\
\text { true for me }\end{array}$ & $\begin{array}{l}\text { Often } \\
\text { true for } \\
\text { me }\end{array}$ & $\begin{array}{l}\text { Usually } \\
\text { true for } \\
\text { me }\end{array}$ & $\begin{array}{c}\text { Always } \\
\text { true for } \\
\text { me }\end{array}$ \\
\hline $\begin{array}{l}\text { 5. When I go to college, I plan } \\
\text { to major in science. }\end{array}$ & $\begin{array}{l}\text { Never } \\
\text { true for } \\
\text { me }\end{array}$ & $\begin{array}{l}\text { Sometimes } \\
\text { true for me }\end{array}$ & $\begin{array}{l}\text { Often } \\
\text { true for } \\
\text { me }\end{array}$ & $\begin{array}{l}\text { Usually } \\
\text { true for } \\
\text { me }\end{array}$ & $\begin{array}{c}\text { Always } \\
\text { true for } \\
\text { me }\end{array}$ \\
\hline $\begin{array}{l}\text { 6. I have become more aware of } \\
\text { the environment because of } \\
\text { my science lessons. }\end{array}$ & $\begin{array}{l}\text { Never } \\
\text { true for } \\
\text { me }\end{array}$ & $\begin{array}{l}\text { Sometimes } \\
\text { true for me }\end{array}$ & $\begin{array}{l}\text { Often } \\
\text { true for } \\
\text { me }\end{array}$ & $\begin{array}{l}\text { Usually } \\
\text { true for } \\
\text { me }\end{array}$ & $\begin{array}{l}\text { Always } \\
\text { true for } \\
\text { me }\end{array}$ \\
\hline $\begin{array}{l}\text { 7. I think you can get along } \\
\text { perfectly well in everyday } \\
\text { life without science. }\end{array}$ & $\begin{array}{l}\text { Never } \\
\text { true for } \\
\text { me }\end{array}$ & $\begin{array}{l}\text { Sometimes } \\
\text { true for me }\end{array}$ & $\begin{array}{l}\text { Often } \\
\text { true for } \\
\text { me }\end{array}$ & $\begin{array}{l}\text { Usually } \\
\text { true for } \\
\text { me }\end{array}$ & $\begin{array}{l}\text { Always } \\
\text { true for } \\
\text { me }\end{array}$ \\
\hline $\begin{array}{l}\text { 8. I think it's important to study } \\
\text { the local animals and plants } \\
\text { and their relationships. }\end{array}$ & $\begin{array}{l}\text { Never } \\
\text { true for } \\
\text { me }\end{array}$ & $\begin{array}{l}\text { Sometimes } \\
\text { true for me }\end{array}$ & $\begin{array}{l}\text { Often } \\
\text { true for } \\
\text { me }\end{array}$ & $\begin{array}{l}\text { Usually } \\
\text { true for } \\
\text { me }\end{array}$ & $\begin{array}{l}\text { Always } \\
\text { true for } \\
\text { me }\end{array}$ \\
\hline $\begin{array}{l}\text { 9. I would rather be given the } \\
\text { right answer to a science } \\
\text { problem than to work it out } \\
\text { myself. }\end{array}$ & $\begin{array}{l}\text { Never } \\
\text { true for } \\
\text { me }\end{array}$ & $\begin{array}{l}\text { Sometimes } \\
\text { true for me }\end{array}$ & $\begin{array}{l}\text { Often } \\
\text { true for } \\
\text { me }\end{array}$ & $\begin{array}{l}\text { Usually } \\
\text { true for } \\
\text { me }\end{array}$ & $\begin{array}{c}\text { Always } \\
\text { true for } \\
\text { me }\end{array}$ \\
\hline $\begin{array}{l}\text { 10. I believe you can learn } \\
\text { science in lots of places, not } \\
\text { only laboratories or } \\
\text { classrooms. }\end{array}$ & $\begin{array}{l}\text { Never } \\
\text { true for } \\
\text { me }\end{array}$ & $\begin{array}{l}\text { Sometimes } \\
\text { true for me }\end{array}$ & $\begin{array}{l}\text { Often } \\
\text { true for } \\
\text { me }\end{array}$ & $\begin{array}{c}\text { Usually } \\
\text { true for } \\
\text { me }\end{array}$ & $\begin{array}{c}\text { Always } \\
\text { true for } \\
\text { me }\end{array}$ \\
\hline $\begin{array}{l}\text { 11. I am more curious about } \\
\text { plants, animals, earth and } \\
\text { universe because of my } \\
\text { science lessons. }\end{array}$ & $\begin{array}{l}\text { Never } \\
\text { true for } \\
\text { me }\end{array}$ & $\begin{array}{l}\text { Sometimes } \\
\text { true for me }\end{array}$ & $\begin{array}{c}\text { Often } \\
\text { true for } \\
\text { me }\end{array}$ & $\begin{array}{c}\text { Usually } \\
\text { true for } \\
\text { me }\end{array}$ & $\begin{array}{c}\text { Always } \\
\text { true for } \\
\text { me }\end{array}$ \\
\hline 12. I believe that what is known & Never & Sometimes & Often & Usually & Always \\
\hline
\end{tabular}




\begin{tabular}{|l|c|c|c|c|c|}
\hline $\begin{array}{l}\text { about a scientific field like } \\
\text { ecology changes as scientists } \\
\text { come up with new ideas from } \\
\text { their experiments. }\end{array}$ & $\begin{array}{c}\text { true for } \\
\text { me }\end{array}$ & true for me & $\begin{array}{c}\text { true for } \\
\text { me }\end{array}$ & $\begin{array}{c}\text { true for } \\
\text { me }\end{array}$ & $\begin{array}{c}\text { true for } \\
\text { me }\end{array}$ \\
\hline $\begin{array}{l}\text { 13. I like trying to find the } \\
\text { answers to scientific } \\
\text { questions by doing } \\
\text { experiments, collecting data, } \\
\text { and interpreting the meaning } \\
\text { of the data. }\end{array}$ & $\begin{array}{c}\text { Never } \\
\text { true for } \\
\text { me }\end{array}$ & $\begin{array}{c}\text { Sometimes } \\
\text { true for me }\end{array}$ & $\begin{array}{c}\text { Often } \\
\text { true for } \\
\text { me }\end{array}$ & $\begin{array}{c}\text { Usually } \\
\text { true for } \\
\text { me }\end{array}$ & $\begin{array}{c}\text { Always } \\
\text { true for } \\
\text { me }\end{array}$ \\
\hline $\begin{array}{l}\text { 14. I enjoy learning science from } \\
\text { guests who visit our } \\
\text { classroom and help our } \\
\text { teacher with science lessons }\end{array}$ & $\begin{array}{c}\text { Never } \\
\text { true for } \\
\text { me }\end{array}$ & Sometimes \\
true for me & $\begin{array}{c}\text { Often } \\
\text { true for } \\
\text { me }\end{array}$ & $\begin{array}{c}\text { Usually } \\
\text { true for } \\
\text { me }\end{array}$ & $\begin{array}{c}\text { Always } \\
\text { true for } \\
\text { me }\end{array}$ \\
\hline $\begin{array}{l}\text { 15. Science is my favorite class. } \\
\text { Sever }\end{array}$ & $\begin{array}{c}\text { Neve for } \\
\text { me }\end{array}$ & $\begin{array}{c}\text { Sometimes } \\
\text { true for me }\end{array}$ & $\begin{array}{c}\text { Often } \\
\text { true for } \\
\text { me }\end{array}$ & $\begin{array}{c}\text { Usually } \\
\text { true for } \\
\text { me }\end{array}$ & $\begin{array}{c}\text { Always } \\
\text { true for } \\
\text { me }\end{array}$ \\
\hline
\end{tabular}




\section{APPENDIX B: TABLES OF RESULTS}

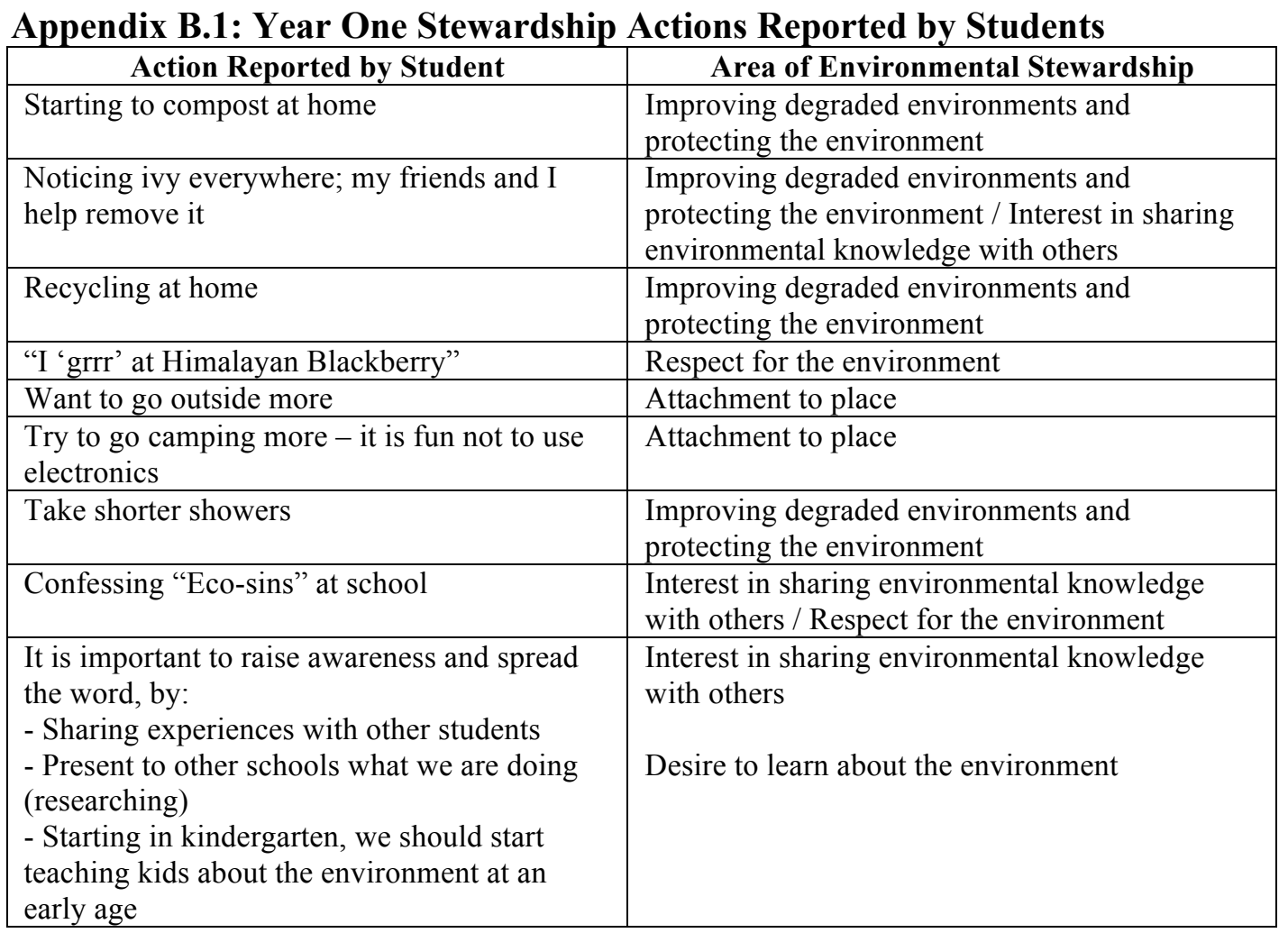




Appendix B.2: Year One Stewardship Actions Reported by Parents
\begin{tabular}{|l|l|}
\hline \multicolumn{1}{|c|}{ Action Reported by Parent } & \multicolumn{1}{c|}{ Area of Environmental Stewardship } \\
\hline Child notices more ivy & Respect for the environment \\
\hline $\begin{array}{l}\text { Child taught mom about ivy (how it is taking } \\
\text { over, how it shouldn't be grown in the } \\
\text { backyard) }\end{array}$ & $\begin{array}{l}\text { Interest in sharing environmental knowledge } \\
\text { with others / Improving degraded environments } \\
\text { and protecting the environment }\end{array}$ \\
\hline $\begin{array}{l}\text { Confidence in identifying different species, the } \\
\text { effects different species have on one another, } \\
\text { "that he can master this [environmental] area of } \\
\text { science" }\end{array}$ & Desire to learn about the environment \\
\hline Child is more engaged in the local environment & $\begin{array}{l}\text { Respect for the environment / Attachment to } \\
\text { place }\end{array}$ \\
\hline $\begin{array}{l}\text { When hiking, the child will identify invasive } \\
\text { plants and name plants }\end{array}$ & $\begin{array}{l}\text { Desire to learn about the environment / Interest } \\
\text { in sharing environmental knowledge with } \\
\text { others }\end{array}$ \\
\hline $\begin{array}{l}\text { Child will teach other students in a way that } \\
\text { that they can understand (ex. river changes) }\end{array}$ & $\begin{array}{l}\text { Interest in sharing environmental knowledge } \\
\text { with others }\end{array}$ \\
\hline $\begin{array}{l}\text { Influencing others: "Dad, do you really need } \\
\text { that much fertilizer?" }\end{array}$ & $\begin{array}{l}\text { Interest in sharing environmental knowledge } \\
\text { with others / Respect for the environment / } \\
\text { Improving degraded environments and } \\
\text { protecting the environment }\end{array}$ \\
\hline $\begin{array}{l}\text { Starting a compost bin at home, asking her } \\
\text { daughter how to do it }\end{array}$ & $\begin{array}{l}\text { Improving degraded environments and } \\
\text { protecting the environment / Interest in sharing } \\
\text { environmental knowledge with others }\end{array}$ \\
\hline $\begin{array}{l}\text { Daughter wants a scooter because it is less } \\
\text { destructive to the environment }\end{array}$ & $\begin{array}{l}\text { Improving degraded environments and } \\
\text { protecting the environment }\end{array}$ \\
\hline $\begin{array}{l}\text { Child talks to his soccer team encouraging } \\
\text { them to ride bikes and compost }\end{array}$ & $\begin{array}{l}\text { Interest in sharing environmental knowledge } \\
\text { with others }\end{array}$ \\
\hline
\end{tabular}




\begin{tabular}{|c|c|}
\hline Action Reported by Teacher & Area of Environmental Stewardship \\
\hline $\begin{array}{l}\text { In new spaces they visit, really want to remove } \\
\text { the ivy; lots of energy behind the desire to } \\
\text { remove ivy }\end{array}$ & $\begin{array}{l}\text { Improving degraded environments and } \\
\text { protecting the environment }\end{array}$ \\
\hline $\begin{array}{l}\text { There is no "away." Garbage, once it's gone, } \\
\text { it's not really gone, it has to go somewhere. } \\
\text { Students are ganging up on teachers that are } \\
\text { considered "Eco-terrorists" when throwing } \\
\text { away paper in the trash (There is recycling } \\
\text { around the school) }\end{array}$ & $\begin{array}{l}\text { Respect for the environment / Interest in } \\
\text { sharing environmental knowledge with others }\end{array}$ \\
\hline $\begin{array}{l}\text { Student told another student not to step on a } \\
\text { bug on the sidewalk; it is an herbaceous } \\
\text { arthropod, because she knew about them she } \\
\text { cared to protect it }\end{array}$ & $\begin{array}{l}\text { Interest in sharing environmental knowledge } \\
\text { with others / Respect for the environment / } \\
\text { Desire to learn about the environment }\end{array}$ \\
\hline $\begin{array}{l}\text { In her Ecoclub, the students confess "Eco-sins" } \\
\text { that they have committed including: long, hot } \\
\text { showers, electronic waste (lots of iPods, etc.) } \\
\text { and fashinistas (buying lots of shoes) }\end{array}$ & $\begin{array}{l}\text { Interest in sharing environmental knowledge } \\
\text { with others / Respect for the environment }\end{array}$ \\
\hline $\begin{array}{l}\text { One student makes her family going back to } \\
\text { places where students have worked; show } \\
\text { parents what they have done }\end{array}$ & $\begin{array}{l}\text { Interest in sharing environmental knowledge } \\
\text { with others / Attachment to place }\end{array}$ \\
\hline $\begin{array}{l}\text { One dad got involved in the park that the } \\
\text { students walk through, set up with Tualatin } \\
\text { Hills to restore the park (invasive species } \\
\text { removed, } 600+\text { plants planted, students } \\
\text { involved with volunteering at the site) }\end{array}$ & $\begin{array}{l}\text { Interest in sharing environmental knowledge } \\
\text { with others / Attachment to place / Improving } \\
\text { degraded environments and protecting the } \\
\text { environment }\end{array}$ \\
\hline $\begin{array}{l}\text { One parent hired some students to remove } \\
\text { [invasive] blackberry from her backyard; kids } \\
\text { loved it! }\end{array}$ & $\begin{array}{l}\text { Improving degraded environments and } \\
\text { protecting the environment }\end{array}$ \\
\hline $\begin{array}{l}\text { Students can't leave the spot until the } \\
\text { [invasive] blackberry is removed; very } \\
\text { motivated }\end{array}$ & $\begin{array}{l}\text { Improving degraded environments and } \\
\text { protecting the environment }\end{array}$ \\
\hline $\begin{array}{l}\text { One girl who said, "I've never looked at a leaf } \\
\text { before and they're beautiful" }\end{array}$ & Respect for the environment \\
\hline $\begin{array}{l}\text { At the end of the project there were kids who } \\
\text { thanked me for taking them outside. I also } \\
\text { heard them say "this is cool!" and "why didn't } \\
\text { we do this sooner?" }\end{array}$ & $\begin{array}{l}\text { Attachment to place / Desire to learn about the } \\
\text { environment }\end{array}$ \\
\hline
\end{tabular}




\section{Appendix B.4: Year Two Stewardship Actions Reported by Students Before their Projects}

\begin{tabular}{|c|c|}
\hline \multirow{2}{*}{\multicolumn{2}{|c|}{$\begin{array}{l}\text { November } 9,2010-6^{\text {th }} \text { Grade, } 6 \text { boys } \mid \text { November } 16,2010-6^{\text {th }} \text { Grade, } 3 \text { boys, } 3 \text { girls } \mid \\
\text { November } 18,2010-8^{\text {th }} \text { Grade, } 5 \text { boys, } 1 \text { girl } \mid \text { November } 30,2010-8^{\text {th }} \text { Grade, } 3 \text { boys, } 1 \text { girl } \\
\text { Question: Do you share or teach what you learn about the environment with other people? } \\
\text { Who? }\end{array}$}} \\
\hline & \\
\hline $\begin{array}{l}\text { I talk to my mom when I go home from school; } \\
\text { we talk about environmental issues - removing } \\
\text { blackberry and she tells me how I could do } \\
\text { better at it }\end{array}$ & $\begin{array}{l}\text { Interest in sharing environmental knowledge } \\
\text { with others / Desire to learn about the } \\
\text { environment }\end{array}$ \\
\hline Family & $\begin{array}{l}\text { Interest in sharing environmental knowledge } \\
\text { with others }\end{array}$ \\
\hline $\begin{array}{l}\text { Family, mom, and dad help me do homework, } \\
\text { really helpful }\end{array}$ & $\begin{array}{l}\text { Interest in sharing environmental knowledge } \\
\text { with others }\end{array}$ \\
\hline Family, discuss site visits & $\begin{array}{l}\text { Interest in sharing environmental knowledge } \\
\text { with others }\end{array}$ \\
\hline $\begin{array}{l}\text { Family and friends online, talk about what I did } \\
\text { that day }\end{array}$ & $\begin{array}{l}\text { Interest in sharing environmental knowledge } \\
\text { with others }\end{array}$ \\
\hline Dad, share what we did during the day & $\begin{array}{l}\text { Interest in sharing environmental knowledge } \\
\text { with others }\end{array}$ \\
\hline Friends & $\begin{array}{l}\text { Interest in sharing environmental knowledge } \\
\text { with others }\end{array}$ \\
\hline $\begin{array}{l}\text { Have brought family and friends back to some } \\
\text { of the sites we have visited: hiking at Hoyt } \\
\text { Arboretum, Multnomah Falls, Oregon Food } \\
\text { Bank, SOLV }\end{array}$ & $\begin{array}{l}\text { Interest in sharing environmental knowledge } \\
\text { with others }\end{array}$ \\
\hline $\begin{array}{l}\text { Family, to save energy - turn off the lights } \\
\text { when you leave a room }\end{array}$ & $\begin{array}{l}\text { Interest in sharing environmental knowledge } \\
\text { with others / Improving degraded environments } \\
\text { and protecting the environment }\end{array}$ \\
\hline Parents, photosynthesis & $\begin{array}{l}\text { Interest in sharing environmental knowledge } \\
\text { with others }\end{array}$ \\
\hline Parents and friends, plants & $\begin{array}{l}\text { Interest in sharing environmental knowledge } \\
\text { with others }\end{array}$ \\
\hline $\begin{array}{l}\text { Teach people about nature, hard to do so in my } \\
\text { family because they know more than me; we } \\
\text { teach each other }\end{array}$ & $\begin{array}{l}\text { Interest in sharing environmental knowledge } \\
\text { with others / Desire to learn about the } \\
\text { environment }\end{array}$ \\
\hline $\begin{array}{l}\text { My friend, he has snide people in his house; I } \\
\text { teach him to turn off the lights when leaving a } \\
\text { room, turn off the water when brushing his } \\
\text { teeth - I put up a white board with reminders } \\
\text { on it for him }\end{array}$ & $\begin{array}{l}\text { Interest in sharing environmental knowledge } \\
\text { with others / Improving degraded environments } \\
\text { and protecting the environment }\end{array}$ \\
\hline $\begin{array}{l}\text { Parents, they know a lot of stuff already; talk } \\
\text { about photosynthesis and how the plants take } \\
\text { in air to clean it }\end{array}$ & $\begin{array}{l}\text { Interest in sharing environmental knowledge } \\
\text { with others }\end{array}$ \\
\hline $\begin{array}{l}\text { Family and friends, I identify leaf } \\
\text { characteristics }\end{array}$ & $\begin{array}{l}\text { Interest in sharing environmental knowledge } \\
\text { with others }\end{array}$ \\
\hline I try to make my family recycle more & $\begin{array}{l}\text { Interest in sharing environmental knowledge } \\
\text { with others / Improving degraded environments } \\
\text { and protecting the environment }\end{array}$ \\
\hline $\begin{array}{l}\text { I teach my dad and people that come to park } \\
\text { work parties which invasives should be } \\
\text { removed (blackberry not the sword fern) }\end{array}$ & $\begin{array}{l}\text { Interest in sharing environmental knowledge } \\
\text { with others / Improving degraded environments } \\
\text { and protecting the environment }\end{array}$ \\
\hline
\end{tabular}




\begin{tabular}{|c|c|}
\hline $\begin{array}{l}\text { At Cooper Mountain Nature Park I want to } \\
\text { volunteer this summer to work with younger } \\
\text { kids that come to summer came there }\end{array}$ & $\begin{array}{l}\text { Interest in sharing environmental knowledge } \\
\text { with others }\end{array}$ \\
\hline I answer lots of questions about ivy & $\begin{array}{l}\text { Interest in sharing environmental knowledge } \\
\text { with others }\end{array}$ \\
\hline $\begin{array}{l}\text { My family and friends, I often argue with my } \\
\text { grandma about drilling for oil }\end{array}$ & $\begin{array}{l}\text { Interest in sharing environmental knowledge } \\
\text { with others }\end{array}$ \\
\hline $\begin{array}{l}\text { I try to teach anyone I can! I drive my parents } \\
\text { crazy talking about plants and animals }\end{array}$ & $\begin{array}{l}\text { Interest in sharing environmental knowledge } \\
\text { with others }\end{array}$ \\
\hline $\begin{array}{l}\text { My grandma pays me } \$ 10 \text { an hour to remove } \\
\text { ivy from her yard }\end{array}$ & $\begin{array}{l}\text { Improving degraded environments and } \\
\text { protecting the environment }\end{array}$ \\
\hline \multicolumn{2}{|l|}{ I don't share the information I learn } \\
\hline I talk to my mom and dad & $\begin{array}{l}\text { Interest in sharing environmental knowledge } \\
\text { with others }\end{array}$ \\
\hline $\begin{array}{l}\text { I talk to my parents and get mad at them if they } \\
\text { sometimes don't recycle or leave the TV on for } \\
\text { too long }\end{array}$ & $\begin{array}{l}\text { Interest in sharing environmental knowledge } \\
\text { with others / Improving degraded environments } \\
\text { and protecting the environment }\end{array}$ \\
\hline $\begin{array}{l}\text { When my friends and I are in the woods } \\
\text { playing together I teach them about different } \\
\text { plants that I know }\end{array}$ & $\begin{array}{l}\text { Interest in sharing environmental knowledge } \\
\text { with others }\end{array}$ \\
\hline \multicolumn{2}{|c|}{$\begin{array}{l}\text { Question: Are there specific natural areas that you frequently visit (or would if you could on } \\
\text { your own), which you enjoy? Where? }\end{array}$} \\
\hline Hoyt Arboretum - like pulling ivy; fun to pull & Attachment to place \\
\hline Multnomah Falls - good hike & Attachment to place \\
\hline $\begin{array}{l}\text { I like hiking, fishing, and I want to learn to } \\
\text { hunt }\end{array}$ & Attachment to place \\
\hline $\begin{array}{l}\text { I have a friend with a stream in his backyard } \\
\text { and I love to play there; pulling blackberry, it is } \\
\text { so fun! }\end{array}$ & $\begin{array}{l}\text { Improving degraded environments and } \\
\text { protecting the environment / Attachment to } \\
\text { place }\end{array}$ \\
\hline \multicolumn{2}{|c|}{\begin{tabular}{l|l} 
In the park, I like to play basketball and & \\
lacrosse &
\end{tabular}} \\
\hline $\begin{array}{l}\text { I like the forest by my dad's house; we hike } \\
\text { there and catch frogs and tadpoles in the pond }\end{array}$ & Attachment to place \\
\hline $\begin{array}{l}\text { My grandpa worked at Multnomah Falls, I like } \\
\text { to visit there }\end{array}$ & Attachment to place \\
\hline $\begin{array}{l}\text { My parents and grandparents own a cattle } \\
\text { ranch in Eugene, I like to go there, it was } \\
\text { covered in invasive blackberry and removed it } \\
\text { and planted } 700+\text { trees }\end{array}$ & $\begin{array}{l}\text { Improving degraded environments and } \\
\text { protecting the environment / Attachment to } \\
\text { place }\end{array}$ \\
\hline $\begin{array}{l}\text { Black Butte, I like to hike, ride bikes, play in } \\
\text { the creek }\end{array}$ & Attachment to place \\
\hline $\begin{array}{l}\text { My Uncle's house in Eugene; I like to sit } \\
\text { outside and watch things, pick blackberries and } \\
\text { make a pie }\end{array}$ & Attachment to place \\
\hline I like hiking and riding my bike & Attachment to place \\
\hline Mt. Hood area, I love the snow & Attachment to place \\
\hline I like the Canadian forests & Attachment to place \\
\hline Icy places, I want to go to Antarctica & Attachment to place \\
\hline Autumn Ridge Park, I like to play there & Attachment to place \\
\hline $\begin{array}{l}\text { I want to visits prairies and run through prairies } \\
\text { but I can't because of my allergies }\end{array}$ & Attachment to place \\
\hline Willow Creek Wetlands, Oxbow Park, & Attachment to place \\
\hline
\end{tabular}




\begin{tabular}{|c|c|}
\hline Multnomah Falls & \\
\hline $\begin{array}{l}\text { Ravine by my house, Cooper Mountain Nature } \\
\text { Park, Hoyt Arboritium - I like to bring my } \\
\text { parents }\end{array}$ & $\begin{array}{l}\text { Interest in sharing environmental knowledge } \\
\text { with others / Attachment to place }\end{array}$ \\
\hline SOLV & Attachment to place \\
\hline Oregon Food Bank & Attachment to place \\
\hline The garden outside & Attachment to place \\
\hline The woods and wetland behind the school & Attachment to place \\
\hline My friend's house with woods in his backyard & Attachment to place \\
\hline Woods out in Ridge Park & Attachment to place \\
\hline Mt. Hood area to go fishing & Attachment to place \\
\hline \multicolumn{2}{|c|}{$\begin{array}{l}\text { Question: Outside of what you do in school, what specific activities do you do so that you } \\
\text { can help the environment? }\end{array}$} \\
\hline $\begin{array}{l}\text { Pulled out ivy at home and pulled out } \\
\text { blackberry at home }\end{array}$ & $\begin{array}{l}\text { Improving degraded environments and } \\
\text { protecting the environment }\end{array}$ \\
\hline $\begin{array}{l}\text { Worked in the gardens at the Oregon Food } \\
\text { Bank }\end{array}$ & $\begin{array}{l}\text { Improving degraded environments and } \\
\text { protecting the environment }\end{array}$ \\
\hline $\begin{array}{l}\text { Planted a garden at home growing pears and } \\
\text { tomatoes }\end{array}$ & $\begin{array}{l}\text { Improving degraded environments and } \\
\text { protecting the environment }\end{array}$ \\
\hline $\begin{array}{l}\text { Climbed a tree at home to level out a bird's } \\
\text { nest so that it wouldn't fall; I have seen birds in } \\
\text { it! }\end{array}$ & $\begin{array}{l}\text { Improving degraded environments and } \\
\text { protecting the environment }\end{array}$ \\
\hline Recycle soda cans & $\begin{array}{l}\text { Improving degraded environments and } \\
\text { protecting the environment }\end{array}$ \\
\hline $\begin{array}{l}\text { Remove blackberry from a park behind my } \\
\text { house }\end{array}$ & $\begin{array}{l}\text { Improving degraded environments and } \\
\text { protecting the environment }\end{array}$ \\
\hline Planted native plants at home & $\begin{array}{l}\text { Improving degraded environments and } \\
\text { protecting the environment }\end{array}$ \\
\hline $\begin{array}{l}\text { Pulled ivy at home, then it kept coming back, } \\
\text { so we rototilled it }\end{array}$ & $\begin{array}{l}\text { Improving degraded environments and } \\
\text { protecting the environment }\end{array}$ \\
\hline Removed bush at home and planted new plants & $\begin{array}{l}\text { Improving degraded environments and } \\
\text { protecting the environment }\end{array}$ \\
\hline $\begin{array}{l}\text { At our ranch in Eugene there is a dam there } \\
\text { that we want to remove, it is on our property }\end{array}$ & $\begin{array}{l}\text { Improving degraded environments and } \\
\text { protecting the environment }\end{array}$ \\
\hline $\begin{array}{l}\text { In Sunriver where I visit, there is a river and } \\
\text { pond area where I help pick up trash from the } \\
\text { bike path }\end{array}$ & $\begin{array}{l}\text { Improving degraded environments and } \\
\text { protecting the environment }\end{array}$ \\
\hline I turn off lights when I leave a room & $\begin{array}{l}\text { Improving degraded environments and } \\
\text { protecting the environment }\end{array}$ \\
\hline I turn off water when I'm in the bathroom & $\begin{array}{l}\text { Improving degraded environments and } \\
\text { protecting the environment }\end{array}$ \\
\hline $\begin{array}{l}\text { In this greenspace in our neighborhood I } \\
\text { helped clean up trash that was left behind by } \\
\text { construction workers }\end{array}$ & $\begin{array}{l}\text { Improving degraded environments and } \\
\text { protecting the environment }\end{array}$ \\
\hline Pick up litter in the forest & $\begin{array}{l}\text { Improving degraded environments and } \\
\text { protecting the environment }\end{array}$ \\
\hline $\begin{array}{l}\text { Part of "Earthsavers" and we plant plants, pick } \\
\text { up trash and we want to go and visit a } \\
\text { greenroof }\end{array}$ & $\begin{array}{l}\text { Improving degraded environments and } \\
\text { protecting the environment }\end{array}$ \\
\hline $\begin{array}{l}\text { Hack down invasive plants like ivy and } \\
\text { blackberry }\end{array}$ & $\begin{array}{l}\text { Improving degraded environments and } \\
\text { protecting the environment }\end{array}$ \\
\hline I've been hired to help out in my grandparent's & Improving degraded environments and \\
\hline
\end{tabular}




\begin{tabular}{|c|c|}
\hline $\begin{array}{l}\text { yard killing weeds, removing thorns and } \\
\text { blackberry, and working on ivy removal }\end{array}$ & protecting the environment \\
\hline $\begin{array}{l}\text { I work with my dad at his contracting sites; } \\
\text { while he is building I work to remove invasive } \\
\text { plants like ivy and blackberry }\end{array}$ & $\begin{array}{l}\text { Improving degraded environments and } \\
\text { protecting the environment }\end{array}$ \\
\hline I remove ivy everywhere, parks, etc. & $\begin{array}{l}\text { Improving degraded environments and } \\
\text { protecting the environment }\end{array}$ \\
\hline $\begin{array}{l}\text { Me and my sister go to Autumn Park and } \\
\text { remove ivy off of the trees together }\end{array}$ & $\begin{array}{l}\text { Improving degraded environments and } \\
\text { protecting the environment }\end{array}$ \\
\hline $\begin{array}{l}\text { I go to my grandma's house and pull } \\
\text { blackberry }\end{array}$ & $\begin{array}{l}\text { Improving degraded environments and } \\
\text { protecting the environment }\end{array}$ \\
\hline Turn off the TV & $\begin{array}{l}\text { Improving degraded environments and } \\
\text { protecting the environment }\end{array}$ \\
\hline $\begin{array}{l}\text { My dad goes back and forth from work to eat } \\
\text { lunch at home and I tell him not to do all that } \\
\text { extra driving; he should just pack his lunch }\end{array}$ & $\begin{array}{l}\text { Interest in sharing environmental knowledge } \\
\text { with others / Improving degraded environments } \\
\text { and protecting the environment }\end{array}$ \\
\hline Turn off the lights when I leave the room & $\begin{array}{l}\text { Improving degraded environments and } \\
\text { protecting the environment }\end{array}$ \\
\hline $\begin{array}{l}\text { Our house's energy is partially covered by } \\
\text { wind power }\end{array}$ & $\begin{array}{l}\text { Improving degraded environments and } \\
\text { protecting the environment }\end{array}$ \\
\hline $\begin{array}{l}\text { I'm careful not to print out lots of paper or do } \\
\text { unnecessary printing }\end{array}$ & $\begin{array}{l}\text { Improving degraded environments and } \\
\text { protecting the environment }\end{array}$ \\
\hline $\begin{array}{l}\text { At our farm there are a lot of blackberries and } \\
\text { we are pulling them out; we pull tansy in } \\
\text { Newberg, too }\end{array}$ & $\begin{array}{l}\text { Improving degraded environments and } \\
\text { protecting the environment }\end{array}$ \\
\hline $\begin{array}{l}\text { I try to eat lots of invasive blackberries so their } \\
\text { seeds will not be spread by birds, then I destroy } \\
\text { the blackberry bushes }\end{array}$ & $\begin{array}{l}\text { Improving degraded environments and } \\
\text { protecting the environment }\end{array}$ \\
\hline \multicolumn{2}{|c|}{ Question: How does helping the environment help your community/neighborhood? } \\
\hline $\begin{array}{l}\text { Public transit cuts down on pollution } \\
\text { Conserving water and energy creates less } \\
\text { pollution and leads to fewer power outages }\end{array}$ & $\begin{array}{l}\text { Improving degraded environments and } \\
\text { protecting the environment }\end{array}$ \\
\hline Using public transit saves power and gas & $\begin{array}{l}\text { Improving degraded environments and } \\
\text { protecting the environment }\end{array}$ \\
\hline $\begin{array}{l}\text { Using public transit supports more public } \\
\text { transit, a good thing! }\end{array}$ & $\begin{array}{l}\text { Improving degraded environments and } \\
\text { protecting the environment }\end{array}$ \\
\hline Pick up litter and recycles what she can & $\begin{array}{l}\text { Improving degraded environments and } \\
\text { protecting the environment }\end{array}$ \\
\hline Try to recycle everything we can & $\begin{array}{l}\text { Improving degraded environments and } \\
\text { protecting the environment }\end{array}$ \\
\hline Turn off lights whenever we leave a room & $\begin{array}{l}\text { Improving degraded environments and } \\
\text { protecting the environment }\end{array}$ \\
\hline $\begin{array}{l}\text { Don't waste energy; the source of the energy } \\
\text { pollutes so by using less we are causing less } \\
\text { pollution }\end{array}$ & $\begin{array}{l}\text { Improving degraded environments and } \\
\text { protecting the environment }\end{array}$ \\
\hline $\begin{array}{l}\text { I have worked with my neighbors to help clean } \\
\text { up the woods }\end{array}$ & $\begin{array}{l}\text { Improving degraded environments and } \\
\text { protecting the environment }\end{array}$ \\
\hline $\begin{array}{l}\text { Turning off lights/water - if everyone does it, it } \\
\text { will be effective }\end{array}$ & $\begin{array}{l}\text { Interest in sharing environmental knowledge } \\
\text { with others / Improving degraded environments } \\
\text { and protecting the environment }\end{array}$ \\
\hline $\begin{array}{l}\text { Clean up projects make the neighborhood look } \\
\text { nicer, makes a better habitat for animals which }\end{array}$ & $\begin{array}{l}\text { Improving degraded environments and } \\
\text { protecting the environment }\end{array}$ \\
\hline
\end{tabular}




\begin{tabular}{|c|c|}
\hline tters & \\
\hline $\begin{array}{l}\text { Clean green spaces can be used by more people } \\
\text { and that is helpful }\end{array}$ & $\begin{array}{l}\text { Improving degraded environments and } \\
\text { protecting the environment }\end{array}$ \\
\hline $\begin{array}{l}\text { Improve park habitats so that animals want to } \\
\text { use the natural spaces and not the peoples' } \\
\text { spaces }\end{array}$ & $\begin{array}{l}\text { Improving degraded environments and } \\
\text { protecting the environment }\end{array}$ \\
\hline $\begin{array}{l}\text { By cleaning up the earth for animals we are } \\
\text { cleaning it for us which is healthier for us }\end{array}$ & $\begin{array}{l}\text { Improving degraded environments and } \\
\text { protecting the environment }\end{array}$ \\
\hline $\begin{array}{l}\text { If we leave trash all over the trees/animals will } \\
\text { not have room to reproduce }\end{array}$ & $\begin{array}{l}\text { Improving degraded environments and } \\
\text { protecting the environment }\end{array}$ \\
\hline $\begin{array}{l}\text { We need the oxygen that the trees/plants } \\
\text { produce }\end{array}$ & $\begin{array}{l}\text { Improving degraded environments and } \\
\text { protecting the environment }\end{array}$ \\
\hline \multicolumn{2}{|l|}{$\begin{array}{l}\text { Makes some people happy (like me!) that we } \\
\text { are helping the environment }\end{array}$} \\
\hline $\begin{array}{l}\text { Recycling is reusing material which leads to } \\
\text { less waste }\end{array}$ & $\begin{array}{l}\text { Improving degraded environments and } \\
\text { protecting the environment }\end{array}$ \\
\hline $\begin{array}{l}\text { I teach interested people and/or ignorant people } \\
\text { what plants they should have in their gardens, } \\
\text { why we need plants and trees, and not to be } \\
\text { scared of insects }\end{array}$ & $\begin{array}{l}\text { Interest in sharing environmental knowledge } \\
\text { with others }\end{array}$ \\
\hline $\begin{array}{l}\text { By us removing ivy we can save other people } \\
\text { time }\end{array}$ & $\begin{array}{l}\text { Improving degraded environments and } \\
\text { protecting the environment }\end{array}$ \\
\hline $\begin{array}{l}\text { Ivy pulls down trees which could fall on houses } \\
\text { which is dangerous for people }\end{array}$ & $\begin{array}{l}\text { Improving degraded environments and } \\
\text { protecting the environment / Respect for the } \\
\text { environment }\end{array}$ \\
\hline $\begin{array}{l}\text { When removing blackberry we could be sued } \\
\text { by landowners }\end{array}$ & $\begin{array}{l}\text { Improving degraded environments and } \\
\text { protecting the environment }\end{array}$ \\
\hline $\begin{array}{l}\text { Plant more trees (like with SOLV) leading to } \\
\text { less pollution in the air }\end{array}$ & $\begin{array}{l}\text { Improving degraded environments and } \\
\text { protecting the environment }\end{array}$ \\
\hline $\begin{array}{l}\text { More animals can live there and there will be } \\
\text { more diversity and there will not be one plant } \\
\text { over dominating }\end{array}$ & Respect for the environment \\
\hline $\begin{array}{l}\text { There will be no pest problems because of the } \\
\text { natural predators }\end{array}$ & Respect for the environment \\
\hline \multicolumn{2}{|c|}{$\begin{array}{l}\text { Question: What things have you learned in science class that have changed how you behave } \\
\text { or changed how you feel towards the environment? }\end{array}$} \\
\hline $\begin{array}{l}\text { Leaves are very important to the } \\
\text { environment/earth/air/humans - now I leave } \\
\text { them and let them grow where they are }\end{array}$ & Respect for the environment \\
\hline Sometimes I help support plants to grow better & $\begin{array}{l}\text { Improving degraded environments and } \\
\text { protecting the environment }\end{array}$ \\
\hline $\begin{array}{l}\text { Removing weeds, now I know what should and } \\
\text { shouldn't be removed (native vs. invasive } \\
\text { blackberry) }\end{array}$ & $\begin{array}{l}\text { Desire to learn about the environment / } \\
\text { Improving degraded environments and } \\
\text { protecting the environment }\end{array}$ \\
\hline $\begin{array}{l}\text { Pesticides are unhealthy for the environment; } \\
\text { now we use vinegar }\end{array}$ & $\begin{array}{l}\text { Improving degraded environments and } \\
\text { protecting the environment }\end{array}$ \\
\hline $\begin{array}{l}\text { Learned plant names (scientific and regular); I } \\
\text { share names with my grandpa (he is forester); } \\
\text { point out plants to my mom }\end{array}$ & $\begin{array}{l}\text { Interest in sharing environmental knowledge } \\
\text { with others / Desire to learn about the } \\
\text { environment }\end{array}$ \\
\hline $\begin{array}{l}\text { Now I know that ivy is evil, kills trees, leads to } \\
\text { erosion }\end{array}$ & Desire to learn about the environment \\
\hline Ivy harms the bark of trees and can kill any & Desire to learn about the environment \\
\hline
\end{tabular}




\begin{tabular}{|c|c|}
\hline plant & \\
\hline $\begin{array}{l}\text { The scientific names of plants help you learn } \\
\text { what other plants are }\end{array}$ & Desire to learn about the environment \\
\hline $\begin{array}{l}\text { Plants, makes people more excited about the } \\
\text { environment - the more people learn about the } \\
\text { environment the more active they become } \\
\text { about environmental issues }\end{array}$ & Desire to learn about the environment \\
\hline $\begin{array}{l}\text { Learned to turn off lights when I leave the } \\
\text { house - now I feel guilty if I don't turn them } \\
\text { off }\end{array}$ & $\begin{array}{l}\text { Desire to learn about the environment / } \\
\text { Improving degraded environments and } \\
\text { protecting the environment / Respect for the } \\
\text { environment }\end{array}$ \\
\hline $\begin{array}{l}\text { Learned the parts of plants so now I get upset } \\
\text { when I see people pulling leaves off of the } \\
\text { trees }\end{array}$ & $\begin{array}{l}\text { Desire to learn about the environment / Respect } \\
\text { for the environment }\end{array}$ \\
\hline $\begin{array}{l}\text { The more I know about the plants the more I } \\
\text { don't want to hurt it - hurting the leaves will } \\
\text { destroy the whole structure }\end{array}$ & $\begin{array}{l}\text { Desire to learn about the environment / Respect } \\
\text { for the environment }\end{array}$ \\
\hline $\begin{array}{l}\text { Watching the salmon eggs hatch, I learned how } \\
\text { delicate life really is. }\end{array}$ & $\begin{array}{l}\text { Desire to learn about the environment / Respect } \\
\text { for the environment }\end{array}$ \\
\hline $\begin{array}{l}\text { Now I step carefully because I could be } \\
\text { stepping on an endangered plant }\end{array}$ & Respect for the environment \\
\hline $\begin{array}{l}\text { When we were driving down the road my mom } \\
\text { threw her sandwich out of the window and I } \\
\text { told her not to because it was dangerous to } \\
\text { squirrels (they could come out into the road } \\
\text { and be killed) we also do not want squirrels to } \\
\text { be dependent on people }\end{array}$ & Respect for the environment \\
\hline $\begin{array}{l}\text { What I learn in science relates to a lot of } \\
\text { conversations that I have with my older } \\
\text { brothers }\end{array}$ & $\begin{array}{l}\text { Interest in sharing environmental knowledge } \\
\text { with others }\end{array}$ \\
\hline $\begin{array}{l}\text { I tell my dad that it is dangerous to throw } \\
\text { plastic into the fire and that he shouldn't do it }\end{array}$ & $\begin{array}{l}\text { Interest in sharing environmental knowledge } \\
\text { with others / Improving degraded environments } \\
\text { and protecting the environment }\end{array}$ \\
\hline $\begin{array}{l}\text { I try to make my family understand how to } \\
\text { change their ways like recycling more, walking } \\
\text { more, riding their bikes more, buying paper } \\
\text { plates made from recycled paper, using } \\
\text { reusable bags }\end{array}$ & $\begin{array}{l}\text { Interest in sharing environmental knowledge } \\
\text { with others / Improving degraded environments } \\
\text { and protecting the environment }\end{array}$ \\
\hline $\begin{array}{l}\text { Encourage people to think about the } \\
\text { environment not just what is the easiest thing to } \\
\text { do }\end{array}$ & $\begin{array}{l}\text { Interest in sharing environmental knowledge } \\
\text { with others / Improving degraded environments } \\
\text { and protecting the environment / Respect for } \\
\text { the environment }\end{array}$ \\
\hline $\begin{array}{l}\text { By watching an Inconvenient Truth I learned } \\
\text { that the polar bears are dying because their ice } \\
\text { is melting and they are moving south to } \\
\text { interbreed with other bears }\end{array}$ & Respect for the environment \\
\hline Recycle more, have a compost bin & $\begin{array}{l}\text { Improving degraded environments and } \\
\text { protecting the environment }\end{array}$ \\
\hline $\begin{array}{l}\text { Learned about compost bins and got my family } \\
\text { to get one }\end{array}$ & $\begin{array}{l}\text { Desire to learn about the environment / } \\
\text { Improving degraded environments and } \\
\text { protecting the environment }\end{array}$ \\
\hline Now we want a worm bin & $\begin{array}{l}\text { Improving degraded environments and } \\
\text { protecting the environment }\end{array}$ \\
\hline
\end{tabular}




\begin{tabular}{|c|c|}
\hline Have a solar powered bbq-er & $\begin{array}{l}\text { Improving degraded environments and } \\
\text { protecting the environment }\end{array}$ \\
\hline $\begin{array}{l}\text { Learn about native and invasive plants and try } \\
\text { not to pick the wrong ones }\end{array}$ & $\begin{array}{l}\text { Desire to learn about the environment / Respect } \\
\text { for the environment }\end{array}$ \\
\hline We learn to destroy blackberry & $\begin{array}{l}\text { Desire to learn about the environment / } \\
\text { Improving degraded environments and } \\
\text { protecting the environment }\end{array}$ \\
\hline Learned about invasive nutria & Desire to learn about the environment \\
\hline $\begin{array}{l}\text { Learned how wetlands are good for the } \\
\text { environment and can control for floods }\end{array}$ & Desire to learn about the environment \\
\hline $\begin{array}{l}\text { Learned where energy comes from and now we } \\
\text { are more aware about turning off lights to make } \\
\text { sure that the electricity isn't wasted }\end{array}$ & $\begin{array}{l}\text { Desire to learn about the environment / } \\
\text { Improving degraded environments and } \\
\text { protecting the environment }\end{array}$ \\
\hline $\begin{array}{l}\text { Energy comes from oil, coal, and natural gas } \\
\text { causing pollution emissions as well as taking a } \\
\text { long time to create! }\end{array}$ & Desire to learn about the environment \\
\hline $\begin{array}{l}\text { A number of things come from trees which } \\
\text { make oxygen }\end{array}$ & Respect for the environment \\
\hline \multicolumn{2}{|c|}{ Question: Other thoughts about the environment and why we learn about it? } \\
\hline The environment is cool! Awesome! & Respect for the environment \\
\hline It provides food, oxygen, animals & Desire to learn about the environment \\
\hline The environment allows for us to survive & Respect for the environment \\
\hline $\begin{array}{l}\text { The whole earth is the environment, even } \\
\text { humans and buildings; it is all part of a cool } \\
\text { system }\end{array}$ & Respect for the environment \\
\hline $\begin{array}{l}\text { Everything has a bad (animals have to eat so } \\
\text { another animal has to be eaten; hunting can be } \\
\text { a good thing too like all of the protecting that } \\
\text { hunters do for the animals they want to hunt) }\end{array}$ & Respect for the environment \\
\hline $\begin{array}{l}\text { When I'm outside I can discover, I learn better } \\
\text { by discovering than in a regular classroom } \\
\text { being lectured to }\end{array}$ & Desire to learn about the environment \\
\hline I love fieldwork! & Desire to learn about the environment \\
\hline $\begin{array}{l}\text { It is important that some kids learn about } \\
\text { environmental issues so that it leads to a chain } \\
\text { reaction and a better environment }\end{array}$ & $\begin{array}{l}\text { Desire to learn about the environment / Respect } \\
\text { for the environment }\end{array}$ \\
\hline \multicolumn{2}{|l|}{$\begin{array}{l}\text { Good for teachers to have a job teaching about } \\
\text { the environment }\end{array}$} \\
\hline $\begin{array}{l}\text { The environment is important, we would die } \\
\text { without it; if the animals die then there is no } \\
\text { food for us }\end{array}$ & Respect for the environment \\
\hline I want to be an environmental engineer & STEM \\
\hline \multicolumn{2}{|l|}{ In this school we learn more "life stuff" } \\
\hline $\begin{array}{l}\text { It is good to learn about the environment as } \\
\text { young kids so that it will stay in our minds and } \\
\text { we will grow up to be scientists and fight for } \\
\text { environmental issues (like the rainforest) }\end{array}$ & $\begin{array}{l}\text { STEM / Interest in sharing environmental } \\
\text { knowledge with others }\end{array}$ \\
\hline $\begin{array}{l}\text { I'll be sharing information on wind energy with } \\
5^{\text {th }} \text { graders }\end{array}$ & $\begin{array}{l}\text { Interest in sharing environmental knowledge } \\
\text { with others }\end{array}$ \\
\hline $\begin{array}{l}\text { Humans are in a bad situation, we need to } \\
\text { make some changes and at RC we learn about } \\
\text { making those changes }\end{array}$ & $\begin{array}{l}\text { Desire to learn about the environment / Respect } \\
\text { for the environment }\end{array}$ \\
\hline
\end{tabular}




\begin{tabular}{|l|l|}
\hline It is important to recycle & $\begin{array}{l}\text { Improving degraded environments and } \\
\text { protecting the environment }\end{array}$ \\
\hline Don't want to keep non-native plants & $\begin{array}{l}\text { Improving degraded environments and } \\
\text { protecting the environment }\end{array}$ \\
\hline Don't destroy native animals and their habitat & $\begin{array}{l}\text { Improving degraded environments and } \\
\text { protecting the environment }\end{array}$ \\
\hline $\begin{array}{l}\text { I'm more aware of the human impact on the } \\
\text { planet }\end{array}$ & Respect for the environment \\
\hline Don't plant English ivy, it dominates! & $\begin{array}{l}\text { Improving degraded environments and } \\
\text { protecting the environment }\end{array}$ \\
\hline
\end{tabular}




\section{Appendix B.5: Year Two Stewardship Actions Reported by Students After their Projects}

\begin{tabular}{|c|c|}
\hline \multirow{2}{*}{\multicolumn{2}{|c|}{$\begin{array}{l}\text { May } 3,2011-6^{\text {th }} \text { Grade, } 3 \text { boys. } 3 \text { girls } \mid \text { May } 4,2011-7^{\text {th }} \text { Grade, } 3 \text { boys, } 3 \text { girls } \mid \text { May } 5,2011- \\
8^{\text {th }} \text { Grade, } 4 \text { boys, } 2 \text { girls } \\
\text { Question: Do you share or teach what you learn about the environment with other people? } \\
\text { Who? }\end{array}$}} \\
\hline & \\
\hline $\begin{array}{l}\text { I tell my mom and dad about what we do in } \\
\text { school and how we do it }\end{array}$ & $\begin{array}{l}\text { Interest in sharing environmental knowledge } \\
\text { with others }\end{array}$ \\
\hline $\begin{array}{l}\text { I tell my family what we do in school and how } \\
\text { learn to help the environment }\end{array}$ & $\begin{array}{l}\text { Interest in sharing environmental knowledge } \\
\text { with others / Desire to learn about the } \\
\text { environment }\end{array}$ \\
\hline $\begin{array}{l}\text { I tell my family (especially my parents and } \\
\text { sister), no total strangers, about the work we do } \\
\text { at site visits }\end{array}$ & $\begin{array}{l}\text { Interest in sharing environmental knowledge } \\
\text { with others }\end{array}$ \\
\hline $\begin{array}{l}\text { I tell whatever family or friends are at the } \\
\text { house about what we did that day }\end{array}$ & $\begin{array}{l}\text { Interest in sharing environmental knowledge } \\
\text { with others }\end{array}$ \\
\hline $\begin{array}{l}\text { I tell friends and family and everyone I know } \\
\text { to make them aware of how we help the } \\
\text { environment and how they should too }\end{array}$ & $\begin{array}{l}\text { Interest in sharing environmental knowledge } \\
\text { with others }\end{array}$ \\
\hline $\begin{array}{l}\text { I tell my family about everything: what we are } \\
\text { learning about, how we should be greener, how } \\
\text { my sister shouldn't pick the flowers }\end{array}$ & $\begin{array}{l}\text { Interest in sharing environmental knowledge } \\
\text { with others }\end{array}$ \\
\hline $\begin{array}{l}\text { My parents, I tell them about how they need to } \\
\text { conserve energy and how to keep the garden } \\
\text { healthy }\end{array}$ & $\begin{array}{l}\text { Interest in sharing environmental knowledge } \\
\text { with others / Improving degraded environments } \\
\text { and protecting the environment }\end{array}$ \\
\hline $\begin{array}{l}\text { My parents, friends and family - I encourage } \\
\text { them to turn off the lights }\end{array}$ & $\begin{array}{l}\text { Interest in sharing environmental knowledge } \\
\text { with others / Improving degraded environments } \\
\text { and protecting the environment }\end{array}$ \\
\hline I tell my parents about the $\mathrm{s}$ & ironmental knowledge \\
\hline $\begin{array}{l}\text { I point out to my parents how other people are } \\
\text { planting things on TV wrong }\end{array}$ & ironmental knowledge \\
\hline $\begin{array}{l}\text { I tell my friends interesting facts that I learn on } \\
\text { site visits, like how a wasp lays its eggs in a } \\
\text { leaf and the leaf protects the eggs }\end{array}$ & $\begin{array}{l}\text { Interest in sharing environmental knowledge } \\
\text { with others }\end{array}$ \\
\hline $\begin{array}{l}\text { My sister, she doesn't know anything about the } \\
\text { environment. I take her to where we have } \\
\text { worked at SOLV and show her things and point } \\
\text { out different types of trees. }\end{array}$ & $\begin{array}{l}\text { Interest in sharing environmental knowledge } \\
\text { with others }\end{array}$ \\
\hline $\begin{array}{l}\text { I tell my parents about what I learn, my mom } \\
\text { knows a lot }\end{array}$ & $\begin{array}{l}\text { Interest in sharing environmental knowledge } \\
\text { with others }\end{array}$ \\
\hline $\begin{array}{l}\text { I tell my little brother about the work we do at } \\
\text { SOLV }\end{array}$ & $\begin{array}{l}\text { Interest in sharing environmental knowledge } \\
\text { with others }\end{array}$ \\
\hline $\begin{array}{l}\text { I tell my friends and family and try to convince } \\
\text { them to go on walks/hikes with me and then I } \\
\text { tell them about what I know }\end{array}$ & $\begin{array}{l}\text { Interest in sharing environmental knowledge } \\
\text { with others }\end{array}$ \\
\hline $\begin{array}{l}\text { I'm surprised by what people don't know about } \\
\text { the environment }\end{array}$ & $\begin{array}{l}\text { Interest in sharing environmental knowledge } \\
\text { with others }\end{array}$ \\
\hline Question: Are there specific natural areas, $p$ & s that you frequently visit (or would \\
\hline $\begin{array}{l}\text { Forest Park, Multnomah Falls (I have been } \\
\text { there on site visits and on my own I have done }\end{array}$ & $\begin{array}{l}\text { Improving degraded environments and } \\
\text { protecting the environment / Attachment to }\end{array}$ \\
\hline
\end{tabular}




\begin{tabular}{|c|c|}
\hline some invasives removal), SOLV site & place \\
\hline $\begin{array}{l}\text { Forest Park because it is peaceful and quiet. } \\
\text { Multnomah Falls because I like to see the } \\
\text { water, it is so awesome in winter - I totally } \\
\text { notice the changes in the spring. An area in } \\
\text { Boise that I don't know the name of. }\end{array}$ & $\begin{array}{l}\text { Attachment to place / Respect for the } \\
\text { environment }\end{array}$ \\
\hline $\begin{array}{l}\text { Tualatin Hills nature park I hike with my } \\
\text { family. It is peaceful and quiet and you can } \\
\text { hear the birds and go anytime. }\end{array}$ & $\begin{array}{l}\text { Interest in sharing environmental knowledge } \\
\text { with others / Attachment to place }\end{array}$ \\
\hline $\begin{array}{l}\text { Any natural place! Multnomah Falls is pretty } \\
\text { in the winder, any trails, Forest Park (I like the } \\
\text { stone house there) }\end{array}$ & Attachment to place \\
\hline $\begin{array}{l}\text { Audubon Society where you can see different } \\
\text { birds and there are trails for hiking. I have } \\
\text { gone with my grandma. }\end{array}$ & $\begin{array}{l}\text { Interest in sharing environmental knowledge } \\
\text { with others / Attachment to place }\end{array}$ \\
\hline $\begin{array}{l}\text { Any park that is close by, I like to relax under } \\
\text { trees }\end{array}$ & Attachment to place \\
\hline $\begin{array}{l}\text { Any park that anyone can go to so that we can } \\
\text { all play together }\end{array}$ & Attachment to place \\
\hline I like to go on hikes in Forest Park & Attachment to place \\
\hline I like the mountains, to get away from worries & Attachment to place \\
\hline $\begin{array}{l}\text { Multnomah Falls because I can easily point out } \\
\text { plants there that I know, both natives and } \\
\text { invasives }\end{array}$ & $\begin{array}{l}\text { Desire to learn about the environment / } \\
\text { Attachment to place }\end{array}$ \\
\hline $\begin{array}{l}\text { The tropical rainforest because of the different } \\
\text { tree and animal species. I want to go there and } \\
\text { try to convince the ranchers that they shouldn't } \\
\text { cut down the trees. }\end{array}$ & $\begin{array}{l}\text { Interest in sharing environmental knowledge } \\
\text { with others / Improving degraded environments } \\
\text { and protecting the environment / Attachment to } \\
\text { place }\end{array}$ \\
\hline $\begin{array}{l}\text { I want to go to the African rain forest to try and } \\
\text { stop the poachers there }\end{array}$ & $\begin{array}{l}\text { Interest in sharing environmental knowledge } \\
\text { with others / Improving degraded environments } \\
\text { and protecting the environment / Attachment to } \\
\text { place }\end{array}$ \\
\hline Olympic Peninsula & Attachment to place \\
\hline Olympic Peninsula & Attachment to place \\
\hline Forest Park, I like to remove ivy there & $\begin{array}{l}\text { Improving degraded environments and } \\
\text { protecting the environment / Attachment to } \\
\text { place }\end{array}$ \\
\hline $\begin{array}{l}\text { I want to go down to the Gulf region and help } \\
\text { clean the birds that there that were impacted by } \\
\text { the oil spill }\end{array}$ & $\begin{array}{l}\text { Improving degraded environments and } \\
\text { protecting the environment / Attachment to } \\
\text { place }\end{array}$ \\
\hline $\begin{array}{l}\text { There is a place by my old house with a } \\
\text { meadow that I really liked }\end{array}$ & Attachment to place \\
\hline \multicolumn{2}{|c|}{$\begin{array}{l}\text { Question: Outside what you have done in school, what specific activities do you do so that } \\
\text { you can help the environment? }\end{array}$} \\
\hline $\begin{array}{l}\text { Whenever it is sunny out, I never use the } \\
\text { thermostat in my house at night; I put reflectors } \\
\text { on my windows to keep the room warm. }\end{array}$ & $\begin{array}{l}\text { Improving degraded environments and } \\
\text { protecting the environment }\end{array}$ \\
\hline $\begin{array}{l}\text { I have gone caving at the Cheese Cave and it } \\
\text { had lots of trash that we removed and cleaned } \\
\text { up to help the different animals that live there. }\end{array}$ & $\begin{array}{l}\text { Improving degraded environments and } \\
\text { protecting the environment / Respect for the } \\
\text { environment }\end{array}$ \\
\hline $\begin{array}{l}\text { We have turned down the thermostat in our } \\
\text { house, we camp a lot. Found a tire and rolled it }\end{array}$ & $\begin{array}{l}\text { Improving degraded environments and } \\
\text { protecting the environment }\end{array}$ \\
\hline
\end{tabular}




\begin{tabular}{|c|c|}
\hline $\begin{array}{l}\text { down a hill and then dragged it back up so that } \\
\text { it could be disposed of. }\end{array}$ & \\
\hline $\begin{array}{l}\text { Beach cleanup in Newport, remove rope that } \\
\text { the fishermen have left on the beach }\end{array}$ & $\begin{array}{l}\text { Improving degraded environments and } \\
\text { protecting the environment }\end{array}$ \\
\hline $\begin{array}{l}\text { I do litter removal from the ground all of the } \\
\text { time with my family. We only use the furnace } \\
\text { when we have to. }\end{array}$ & $\begin{array}{l}\text { Improving degraded environments and } \\
\text { protecting the environment }\end{array}$ \\
\hline $\begin{array}{l}\text { My family volunteers at environmental places: } \\
\text { we have pulled dandelions. We try to use as } \\
\text { little light as possible and I volunteer to clear } \\
\text { weeds }\end{array}$ & $\begin{array}{l}\text { Interest in sharing environmental knowledge } \\
\text { with others / Improving degraded environments } \\
\text { and protecting the environment }\end{array}$ \\
\hline $\begin{array}{l}\text { I use a powerstrip in my bedroom for my } \\
\text { computer so that I can turn off the electricity to } \\
\text { it. My guinea pig uses environmentally } \\
\text { friendly bedding. We turn the lights off when } \\
\text { we leave the house. }\end{array}$ & $\begin{array}{l}\text { Improving degraded environments and } \\
\text { protecting the environment }\end{array}$ \\
\hline $\begin{array}{l}\text { I turn off the lights in my house when I go to } \\
\text { bed and try to use as much daylight as possible } \\
\text { and not watch a lot of TV }\end{array}$ & $\begin{array}{l}\text { Improving degraded environments and } \\
\text { protecting the environment }\end{array}$ \\
\hline $\begin{array}{l}\text { In the wetlands behind my house, my family } \\
\text { has removed some blackberry there }\end{array}$ & $\begin{array}{l}\text { Interest in sharing environmental knowledge } \\
\text { with others / Improving degraded environments } \\
\text { and protecting the environment }\end{array}$ \\
\hline We have a compost pile that we try to use often & $\begin{array}{l}\text { Improving degraded environments and } \\
\text { protecting the environment }\end{array}$ \\
\hline I take bottles and cans in to be recycled & $\begin{array}{l}\text { Improving degraded environments and } \\
\text { protecting the environment }\end{array}$ \\
\hline $\begin{array}{l}\text { We try to take shorter showers and bang on the } \\
\text { door if someone is taking too long }\end{array}$ & $\begin{array}{l}\text { Improving degraded environments and } \\
\text { protecting the environment }\end{array}$ \\
\hline $\begin{array}{l}\text { I try to do the little stuff like recycling, taking } \\
\text { shorter showers, keeping the water on for only } \\
\text { short periods of time - I think that the small } \\
\text { steps add up to a big step }\end{array}$ & $\begin{array}{l}\text { Improving degraded environments and } \\
\text { protecting the environment }\end{array}$ \\
\hline Ride my bike to school & $\begin{array}{l}\text { Improving degraded environments and } \\
\text { protecting the environment }\end{array}$ \\
\hline $\begin{array}{l}\text { Try to convince my parents to go for } 0 \text { food } \\
\text { waste }\end{array}$ & $\begin{array}{l}\text { Improving degraded environments and } \\
\text { protecting the environment }\end{array}$ \\
\hline Remove ivy & $\begin{array}{l}\text { Improving degraded environments and } \\
\text { protecting the environment }\end{array}$ \\
\hline $\begin{array}{l}\text { Do a project about a movie about the } \\
\text { environment }\end{array}$ & $\begin{array}{l}\text { Desire to learn about the environment / } \\
\text { Improving degraded environments and } \\
\text { protecting the environment }\end{array}$ \\
\hline Ride the bus to school everyday & $\begin{array}{l}\text { Improving degraded environments and } \\
\text { protecting the environment }\end{array}$ \\
\hline Pull ivy everywhere I see it & $\begin{array}{l}\text { Improving degraded environments and } \\
\text { protecting the environment }\end{array}$ \\
\hline $\begin{array}{l}\text { I'm conscious about trail health, I notice a lot } \\
\text { of invasives }\end{array}$ & $\begin{array}{l}\text { Improving degraded environments and } \\
\text { protecting the environment }\end{array}$ \\
\hline I pick up litter more & $\begin{array}{l}\text { Improving degraded environments and } \\
\text { protecting the environment }\end{array}$ \\
\hline $\begin{array}{l}\text { When I ride my bike with my friends I stay on } \\
\text { trail and try to convince them to do the same }\end{array}$ & $\begin{array}{l}\text { Improving degraded environments and } \\
\text { protecting the environment / Interest in sharing } \\
\text { environmental knowledge with others / Respect }\end{array}$ \\
\hline
\end{tabular}




\begin{tabular}{|c|c|}
\hline & for the environment \\
\hline \multicolumn{2}{|c|}{ Question: How does helping the environment help your neighborhood/community? } \\
\hline $\begin{array}{l}\text { By postponing global warming and using less } \\
\text { fuels the neighborhood would be cooler than it } \\
\text { could be. }\end{array}$ & Desire to learn about the environment \\
\hline $\begin{array}{l}\text { Some people (my friend) believes that global } \\
\text { warming isn't happening, I try to convince her } \\
\text { otherwise }\end{array}$ & $\begin{array}{l}\text { Interest in sharing environmental knowledge } \\
\text { with others }\end{array}$ \\
\hline $\begin{array}{l}\text { We wash cars at the station and not in the } \\
\text { driveway so that the water doesn't pollute the } \\
\text { plants and soil }\end{array}$ & $\begin{array}{l}\text { Improving degraded environments and } \\
\text { protecting the environment }\end{array}$ \\
\hline $\begin{array}{l}\text { Less pollution around neighborhoods will have } \\
\text { more oxygen in the air. I encourage people to } \\
\text { drive slower so that there is less pollution from } \\
\text { their cars }\end{array}$ & $\begin{array}{l}\text { Improving degraded environments and } \\
\text { protecting the environment }\end{array}$ \\
\hline $\begin{array}{l}\text { Pesticides can cause cancer so by not using } \\
\text { them it eliminates cancer from the community }\end{array}$ & $\begin{array}{l}\text { Desire to learn about the environment / } \\
\text { Improving degraded environments and } \\
\text { protecting the environment }\end{array}$ \\
\hline $\begin{array}{l}\text { We have sold our bigger cars to decrease gas } \\
\text { emissions and have switched to smaller cars, } \\
\text { keeping less } \mathrm{CO} 2 \text { from entering the air }\end{array}$ & $\begin{array}{l}\text { Improving degraded environments and } \\
\text { protecting the environment }\end{array}$ \\
\hline $\begin{array}{l}\text { When I grow up I want to make a car that is } \\
\text { totally environmentally friendly using a fan to } \\
\text { create electricity - could also make a car that } \\
\text { runs off of } \mathrm{CO} 2\end{array}$ & $\begin{array}{l}\text { Desire to learn about the environment / } \\
\text { Improving degraded environments and } \\
\text { protecting the environment }\end{array}$ \\
\hline $\begin{array}{l}\text { Working on environmental projects can bring } \\
\text { people together, for example, if they were to } \\
\text { plant similar vegetables in a community garden } \\
\text { then they could have a conversation and bring } \\
\text { people together }\end{array}$ & $\begin{array}{l}\text { Interest in sharing environmental knowledge } \\
\text { with others }\end{array}$ \\
\hline Helping the environment helps animals & $\begin{array}{l}\text { Improving degraded environments and } \\
\text { protecting the environment }\end{array}$ \\
\hline $\begin{array}{l}\text { Helping the environment makes for a nicer } \\
\text { place to live - it lowers water and electricity } \\
\text { bills. We feel like a community when we all } \\
\text { work towards the same goal }\end{array}$ & $\begin{array}{l}\text { Improving degraded environments and } \\
\text { protecting the environment }\end{array}$ \\
\hline $\begin{array}{l}\text { It is important to clean up roads and pick up } \\
\text { trash }\end{array}$ & $\begin{array}{l}\text { Improving degraded environments and } \\
\text { protecting the environment }\end{array}$ \\
\hline $\begin{array}{l}\text { Having a cleaner environment will result in a } \\
\text { healthier lifestyle for people - no one wants to } \\
\text { go to a trashy park or a dirty street }\end{array}$ & $\begin{array}{l}\text { Improving degraded environments and } \\
\text { protecting the environment }\end{array}$ \\
\hline $\begin{array}{l}\text { The environment (forests and parks) is what } \\
\text { really makes a neighborhood; that is where } \\
\text { kids go to play }\end{array}$ & Attachment to place \\
\hline $\begin{array}{l}\text { Without the environment we wouldn't have } \\
\text { food or resources }\end{array}$ & Respect for the environment \\
\hline $\begin{array}{l}\text { The quality of the environment affects animals } \\
\text { - better habitat for natural animals may be } \\
\text { worse for domestic animals }\end{array}$ & Respect for the environment \\
\hline $\begin{array}{l}\text { Helping natural areas near a neighborhood is } \\
\text { important and so is keeping dogs on leash so } \\
\text { they do not disturb the animals }\end{array}$ & $\begin{array}{l}\text { Improving degraded environments and } \\
\text { protecting the environment }\end{array}$ \\
\hline Detergent in a stream is a problem & \\
\hline
\end{tabular}




\begin{tabular}{|c|c|}
\hline \multicolumn{2}{|l|}{ Washing cars is bad for the environment } \\
\hline Helping the environment provides jobs & \\
\hline Helping the environment provides habitat & Respect for the environment \\
\hline \multicolumn{2}{|c|}{$\begin{array}{l}\text { Question: What things have you learned in science class that have changed how you behave } \\
\text { or changes how you feel towards the environment? }\end{array}$} \\
\hline $\begin{array}{l}\text { Learned how to remove blackberry and it has } \\
\text { opened my eyes to what is really out there } \\
\text { (problems with oil rigs, trash in the oceans, } \\
\text { etc.) }\end{array}$ & $\begin{array}{l}\text { Desire to learn about the environment / } \\
\text { Improving degraded environments and } \\
\text { protecting the environment }\end{array}$ \\
\hline $\begin{array}{l}\text { I encourage my community to use less water, } \\
\text { reuse things, and to create less trash }\end{array}$ & $\begin{array}{l}\text { Interest in sharing environmental knowledge } \\
\text { with others / Improving degraded environments } \\
\text { and protecting the environment }\end{array}$ \\
\hline $\begin{array}{l}\text { We have learned about what is around us and it } \\
\text { has made us more aware }\end{array}$ & $\begin{array}{l}\text { Desire to learn about the environment / Respect } \\
\text { for the environment }\end{array}$ \\
\hline $\begin{array}{l}\text { Here at RC I learned why problems are } \\
\text { happening and how to change it }\end{array}$ & $\begin{array}{l}\text { Desire to learn about the environment / Respect } \\
\text { for the environment }\end{array}$ \\
\hline Now I know how trash effects the environment & Desire to learn about the environment \\
\hline $\begin{array}{l}\text { I value food more because I understand how } \\
\text { difficult it is to grow elsewhere }\end{array}$ & Desire to learn about the environment \\
\hline $\begin{array}{l}\text { When we first started going outside I didn't } \\
\text { realize how connected we all are together }\end{array}$ & Respect for the environment \\
\hline $\begin{array}{l}\text { I am always naming species, it drives my } \\
\text { friends crazy }\end{array}$ & $\begin{array}{l}\text { Interest in sharing environmental knowledge } \\
\text { with others / Desire to learn about the } \\
\text { environment }\end{array}$ \\
\hline I constantly want to go outside now & Attachment to place \\
\hline $\begin{array}{l}\text { What I learn in school (like math) I never think } \\
\text { that I will use but the stuff that we learn in } \\
\text { science I use all of the time }\end{array}$ & Desire to learn about the environment \\
\hline $\begin{array}{l}\text { I used to think that blackberry was good to eat } \\
\text { but now I see it as an invasive and it dominates } \\
\text { everything and takes over }\end{array}$ & Desire to learn about the environment \\
\hline $\begin{array}{l}\text { Ivy dominates houses and I know that it is a } \\
\text { problem }\end{array}$ & Desire to learn about the environment \\
\hline Ivy can take over a forest & Desire to learn about the environment \\
\hline I have always been environmentally conscious & Respect for the environment \\
\hline $\begin{array}{l}\text { Learned that clear cutting can be good for a } \\
\text { forest, sometimes better than wildfires. Not } \\
\text { everyone thinks this way - there is a more } \\
\text { educated way to look at it }\end{array}$ & $\begin{array}{l}\text { Interest in sharing environmental knowledge } \\
\text { with others / Desire to learn about the } \\
\text { environment }\end{array}$ \\
\hline $\begin{array}{l}\text { Forest fire control is a huge problem because of } \\
\text { all of the debris that when there is one it will be } \\
\text { really big }\end{array}$ & Desire to learn about the environment \\
\hline Now I don't break branches off of trees & $\begin{array}{l}\text { Improving degraded environments and } \\
\text { protecting the environment }\end{array}$ \\
\hline $\begin{array}{l}\text { I'm more aware about how plants and animals } \\
\text { effect each other }\end{array}$ & Desire to learn about the environment \\
\hline \multicolumn{2}{|c|}{$\begin{array}{l}\text { Question: Has taking part in a long-term project (Hoyt, SOLV, etc.) changed anything } \\
\text { about how you think about the environment? }\end{array}$} \\
\hline $\begin{array}{l}\text { I used to think that ivy was beautiful before I } \\
\text { started pulling it. }\end{array}$ & $\begin{array}{l}\text { Improving degraded environments and } \\
\text { protecting the environment }\end{array}$ \\
\hline $\begin{array}{l}\text { The site visits have helped me realize how to } \\
\text { help the environment }\end{array}$ & $\begin{array}{l}\text { Improving degraded environments and } \\
\text { protecting the environment / Respect for the }\end{array}$ \\
\hline
\end{tabular}




\begin{tabular}{|c|c|}
\hline & environment \\
\hline $\begin{array}{l}\text { If you mess around with the environment these } \\
\text { animals will come after you }\end{array}$ & Respect for the environment \\
\hline Learned lots about ivy & Desire to learn about the environment \\
\hline $\begin{array}{l}\text { I used to think that you should kill all plants } \\
\text { but now I know that you should just kill } \\
\text { invasives (blackberry and ivy); I have learned } \\
\text { what to do }\end{array}$ & $\begin{array}{l}\text { Desire to learn about the environment / } \\
\text { Improving degraded environments and } \\
\text { protecting the environment }\end{array}$ \\
\hline $\begin{array}{l}\text { I know what the roots are that are hanging from } \\
\text { the ceiling in the classroom - I didn't know } \\
\text { that before; I can ID things now }\end{array}$ & Desire to learn about the environment \\
\hline $\begin{array}{l}\text { Before I didn't know a lot but I wanted to learn } \\
\text { so that I can know a lot like my mom }\end{array}$ & Desire to learn about the environment \\
\hline $\begin{array}{l}\text { I have always liked gardening but now I know } \\
\text { what to remove }\end{array}$ & $\begin{array}{l}\text { Improving degraded environments and } \\
\text { protecting the environment }\end{array}$ \\
\hline I know to destroy the ivy root & $\begin{array}{l}\text { Improving degraded environments and } \\
\text { protecting the environment }\end{array}$ \\
\hline I feel like we all can make a difference & Respect for the environment \\
\hline $\begin{array}{l}\text { After all of the work we do on a site, a } \\
\text { difference has really been made }\end{array}$ & $\begin{array}{l}\text { Improving degraded environments and } \\
\text { protecting the environment / Respect for the } \\
\text { environment }\end{array}$ \\
\hline I have learned how to make things better & Respect for the environment \\
\hline $\begin{array}{l}\text { Learning on hikes about what you can do on } \\
\text { your own }\end{array}$ & $\begin{array}{l}\text { Desire to learn about the environment / Respect } \\
\text { for the environment }\end{array}$ \\
\hline I have removed lots of blackberry & $\begin{array}{l}\text { Improving degraded environments and } \\
\text { protecting the environment }\end{array}$ \\
\hline $\begin{array}{l}\text { I am awed by the amount of work done at the } \\
\text { sites and what we did }\end{array}$ & $\begin{array}{l}\text { Improving degraded environments and } \\
\text { protecting the environment }\end{array}$ \\
\hline $\begin{array}{l}\text { When we were removing blackberry from a } \\
\text { roadside and stop and look back it is really } \\
\text { impressive }\end{array}$ & $\begin{array}{l}\text { Improving degraded environments and } \\
\text { protecting the environment }\end{array}$ \\
\hline $\begin{array}{l}\text { It is fun to do the work with friends because } \\
\text { you can work and talk }\end{array}$ & $\begin{array}{l}\text { Interest in sharing environmental knowledge } \\
\text { with others }\end{array}$ \\
\hline $\begin{array}{l}\text { I appreciate the environment around us and I } \\
\text { know how to change it }\end{array}$ & $\begin{array}{l}\text { Desire to learn about the environment / } \\
\text { Improving degraded environments and } \\
\text { protecting the environment / Respect for the } \\
\text { environment }\end{array}$ \\
\hline $\begin{array}{l}\text { We are not the only ones using this space - } \\
\text { trash in the areas with the animals where the } \\
\text { they have to live - we have to fix it }\end{array}$ & $\begin{array}{l}\text { Improving degraded environments and } \\
\text { protecting the environment / Respect for the } \\
\text { environment }\end{array}$ \\
\hline $\begin{array}{l}\text { I feel good about going to sites but it is hard } \\
\text { because all of the work doesn't amount to } \\
\text { much change very quickly. I am proud that we } \\
\text { are changing the areas, though }\end{array}$ & $\begin{array}{l}\text { Improving degraded environments and } \\
\text { protecting the environment / Respect for the } \\
\text { environment }\end{array}$ \\
\hline They made me want to take action more & $\begin{array}{l}\text { Improving degraded environments and } \\
\text { protecting the environment }\end{array}$ \\
\hline I'm more into helping ecosystems now & $\begin{array}{l}\text { Improving degraded environments and } \\
\text { protecting the environment }\end{array}$ \\
\hline $\begin{array}{l}\text { After working at SOLV and in Forest Park, I'm } \\
\text { happy to see places like that now and I want to } \\
\text { change my own environment to be like that }\end{array}$ & $\begin{array}{l}\text { Improving degraded environments and } \\
\text { protecting the environment }\end{array}$ \\
\hline My definition of school work has defiantly & Desire to learn about the environment \\
\hline
\end{tabular}




\begin{tabular}{|l|l|}
\hline changed & \\
\hline $\begin{array}{l}\text { My definition of community service has } \\
\text { changed }\end{array}$ & \\
\hline $\begin{array}{l}\text { It is fun to do restoration work and I didn't } \\
\text { think that it would be }\end{array}$ & $\begin{array}{l}\text { Improving degraded environments and } \\
\text { protecting the environment }\end{array}$ \\
\hline
\end{tabular}




\section{Appendix B.6: Year Two Responses from Parents about Student Stewardship Attitudes}

\begin{tabular}{|c|c|}
\hline \multicolumn{2}{|c|}{$\begin{array}{l}\text { Question: What changes have you seen in your child that you think are linked to the work } \\
\text { and projects they take part in at this school? }\end{array}$} \\
\hline $\begin{array}{l}\text { They are more environmentally aware and they } \\
\text { now have background to site what she has } \\
\text { learned }\end{array}$ & Desire to learn about the environment \\
\hline \multicolumn{2}{|l|}{ He has always been that way } \\
\hline More observant & Desire to learn about the environment \\
\hline $\begin{array}{l}\text { Having the science fair projects integrated into } \\
\text { the curriculum, they know a lot about the } \\
\text { scientific method giving them a good critical } \\
\text { thinking ability }\end{array}$ & Desire to learn about the environment \\
\hline $\begin{array}{l}\text { On the site visits, the kids work hard and like } \\
\text { to test things; they are all really trying } \\
\text { regardless of their rate of success }\end{array}$ & $\begin{array}{l}\text { Improving degraded environments and } \\
\text { protecting the environment }\end{array}$ \\
\hline \multicolumn{2}{|l|}{$\begin{array}{l}\text { They have good behavior and support each } \\
\text { other; less cliquey than at other middle schools }\end{array}$} \\
\hline \multicolumn{2}{|l|}{$\begin{array}{l}\text { Teachers break up the groups of friends all of } \\
\text { the time and the students don't seem to mind }\end{array}$} \\
\hline $\begin{array}{l}\text { They work in bad conditions (muddy, cold, } \\
\text { rain) and still get the job done; it seems like } \\
\text { they do more work at the SOLV site than in } \\
\text { their regular lives }\end{array}$ & $\begin{array}{l}\text { Attachment to place / Improving degraded } \\
\text { environments and protecting the environment }\end{array}$ \\
\hline $\begin{array}{l}\text { It is easy to get them to see their results at } \\
\text { SOLV }\end{array}$ & $\begin{array}{l}\text { Improving degraded environments and } \\
\text { protecting the environment }\end{array}$ \\
\hline \multicolumn{2}{|c|}{$\begin{array}{l}\text { Question: Specifically, had your child suggested changes your family should make in } \\
\text { regards to changing energy usage, recycling, composting, changing modes of transportation, } \\
\text { planting different plants (removing invasives, planting natives), etc.? }\end{array}$} \\
\hline Aware of which plants are native & Desire to learn about the environment \\
\hline $\begin{array}{l}\text { We have ivy in our yard and she is always } \\
\text { pulling it }\end{array}$ & $\begin{array}{l}\text { Desire to learn about the environment / } \\
\text { Improving degraded environments and } \\
\text { protecting the environment }\end{array}$ \\
\hline $\begin{array}{l}\text { He talks about pollution and energy } \\
\text { consumption }\end{array}$ & $\begin{array}{l}\text { Desire to learn about the environment / Interest } \\
\text { in sharing environmental knowledge with } \\
\text { others }\end{array}$ \\
\hline $\begin{array}{l}\text { When we bought a hybrid car last year my } \\
\text { child did all of the research on fuel efficiency }\end{array}$ & $\begin{array}{l}\text { Desire to learn about the environment / Interest } \\
\text { in sharing environmental knowledge with } \\
\text { others / Improving degraded environments and } \\
\text { protecting the environment }\end{array}$ \\
\hline My child is turning the lights off all the time! & $\begin{array}{l}\text { Improving degraded environments and } \\
\text { protecting the environment }\end{array}$ \\
\hline $\begin{array}{l}\text { My child asked why we didn't have solar } \\
\text { panels on our roof and I had to tell him all } \\
\text { about the energy audit that we had done }\end{array}$ & $\begin{array}{l}\text { Interest in sharing environmental knowledge } \\
\text { with others / Improving degraded environments } \\
\text { and protecting the environment }\end{array}$ \\
\hline My child asks about gas mileage in new cars & $\begin{array}{l}\text { Desire to learn about the environment / } \\
\text { Improving degraded environments and } \\
\text { protecting the environment }\end{array}$ \\
\hline \multicolumn{2}{|c|}{$\begin{array}{l}\text { Question: Are there activities or actions that your family took part in before your child } \\
\text { came to Rachel Carson that could have supported their environmental attitude? How do } \\
\text { you encourage environmental behaviors at home? }\end{array}$} \\
\hline We have a creek in the backyard and she is & Attachment to place \\
\hline
\end{tabular}




\begin{tabular}{|c|c|}
\hline $\begin{array}{l}\text { always bringing in crawdads and eels; I tell her } \\
\text { to put them back where she found them }\end{array}$ & \\
\hline $\begin{array}{l}\text { She gets excited about watching the grey } \\
\text { herons }\end{array}$ & Respect for the environment \\
\hline $\begin{array}{l}\text { She and a friend remove garbage from the } \\
\text { creek all the time and fill up my bins }\end{array}$ & $\begin{array}{l}\text { Improving degraded environments and } \\
\text { protecting the environment }\end{array}$ \\
\hline $\begin{array}{l}\text { We have always recycled and composted; we } \\
\text { reuse plastic bags, reuse containers, use cloth } \\
\text { bags at the grocery store, and buy in bulk to } \\
\text { save on packaging }\end{array}$ & $\begin{array}{l}\text { Improving degraded environments and } \\
\text { protecting the environment }\end{array}$ \\
\hline $\begin{array}{l}\text { My daughter gets very upset if we are ever } \\
\text { wasting food; she says it is so bad! }\end{array}$ & $\begin{array}{l}\text { Improving degraded environments and } \\
\text { protecting the environment / Respect for the } \\
\text { environment }\end{array}$ \\
\hline We garden & $\begin{array}{l}\text { Improving degraded environments and } \\
\text { protecting the environment }\end{array}$ \\
\hline We hike for fun & Attachment to place \\
\hline We camp & Attachment to place \\
\hline We hike & Attachment to place \\
\hline \multicolumn{2}{|c|}{$\begin{array}{l}\text { Question: Have you noticed a change in the amount of time your child spends or wants to } \\
\text { spend outdoors? }\end{array}$} \\
\hline $\begin{array}{l}\text { Once the sun comes out she is outside; we call } \\
\text { her the solar-powered baby }\end{array}$ & Attachment to place \\
\hline He has always liked to spend time outdoors & Attachment to place \\
\hline $\begin{array}{l}\text { He has more homework now so he can't be } \\
\text { outside as much }\end{array}$ & Attachment to place \\
\hline $\begin{array}{l}\text { He would like to be outside as much as } \\
\text { possible but he has always been that way }\end{array}$ & Attachment to place \\
\hline $\begin{array}{l}\text { The outdoor aspect of this school attracted him } \\
\text { to it }\end{array}$ & Attachment to place \\
\hline He would be outdoors anyway & Attachment to place \\
\hline The projects give them good planning skills & Desire to learn about the environment \\
\hline \multicolumn{2}{|c|}{ Question: Does your child teach you about what they learn in school? What specifically? } \\
\hline $\begin{array}{l}\text { Lots about plants and their scientific names } \\
\text { including root nodules and pinnation }\end{array}$ & $\begin{array}{l}\text { Desire to learn about the environment / Interest } \\
\text { in sharing environmental knowledge with } \\
\text { others }\end{array}$ \\
\hline $\begin{array}{l}\text { About non-indigenous plants, asking, "don't } \\
\text { you want to pull the ivy?" }\end{array}$ & $\begin{array}{l}\text { Interest in sharing environmental knowledge } \\
\text { with others / Improving degraded environments } \\
\text { and protecting the environment }\end{array}$ \\
\hline $\begin{array}{l}\text { He identifies reed canary grass and suggests } \\
\text { sites that should be SOLV sites for next year }\end{array}$ & $\begin{array}{l}\text { Interest in sharing environmental knowledge } \\
\text { with others / Improving degraded environments } \\
\text { and protecting the environment }\end{array}$ \\
\hline $\begin{array}{l}\text { I have a few of the students in the carpool and } \\
\text { they talk to each other about systems and } \\
\text { ecosystems in a thoughtful conversation }\end{array}$ & $\begin{array}{l}\text { Desire to learn about the environment / Interest } \\
\text { in sharing environmental knowledge with } \\
\text { others }\end{array}$ \\
\hline $\begin{array}{l}\text { My son is constantly identifying sites that } \\
\text { should be SOLV sites }\end{array}$ & $\begin{array}{l}\text { Interest in sharing environmental knowledge } \\
\text { with others / Improving degraded environments } \\
\text { and protecting the environment }\end{array}$ \\
\hline $\begin{array}{l}\text { They are often spotting blackberry and ivy } \\
\text { saying that they could fix that }\end{array}$ & $\begin{array}{l}\text { Improving degraded environments and } \\
\text { protecting the environment }\end{array}$ \\
\hline $\begin{array}{l}\text { Identifying holly in the backyard and getting } \\
\text { excited about removing it }\end{array}$ & $\begin{array}{l}\text { Interest in sharing environmental knowledge } \\
\text { with others / Improving degraded environments } \\
\text { and protecting the environment / Respect for }\end{array}$ \\
\hline
\end{tabular}




\begin{tabular}{|l|l|}
\hline & the environment \\
\hline $\begin{array}{l}\text { I'm impressed by how this school allows them } \\
\text { to feel competent and gain confidence; they } \\
\text { don't want to leave here; they have the best } \\
\text { experiences of their lives! }\end{array}$ & Respect for the environment \\
\hline $\begin{array}{l}\text { Question: Can you attribute any of the changes you have seen in your child to the projects } \\
\text { they do in school that you may not have mentioned beforehand? Specific examples. }\end{array}$ \\
\hline $\begin{array}{l}\text { She is more observant when watching a show } \\
\text { or reading something }\end{array}$ & Desire to learn about the environment \\
\hline $\begin{array}{l}\text { He has the big picture in mind with the whole } \\
\text { ecosystem }\end{array}$ & Desire to learn about the environment \\
\hline Question: What does your child want to be when they grow up? \\
\hline Veterinarian & STEM \\
\hline Physician & STEM \\
\hline Find a cure for HIV or cancer & STEM \\
\hline Computer graphics or film/movies & STEM \\
\hline They are all over the place & STEM \\
\hline $\begin{array}{l}\text { Abstract art in order to be a video game } \\
\text { designer }\end{array}$ & STEM \\
\hline Architect or engineer & STEM / Respect for the environment \\
\hline $\begin{array}{l}\text { Really excited about doing work like they do in } \\
\text { the FIT group; he gets mad when he has to } \\
\text { miss it }\end{array}$ & \\
\hline
\end{tabular}




\section{Appendix B.7: Year Two Responses from Teachers about Student Stewardship Attitudes}

\begin{tabular}{|c|c|}
\hline \multicolumn{2}{|c|}{$\begin{array}{l}\text { Question: What activities that your students have taken part in so far this school year may } \\
\text { have contributed to their stewardship attitude? }\end{array}$} \\
\hline Teacher & Response \\
\hline $\begin{array}{l}\text { Quinn / RC } \\
\text { Control* }\end{array}$ & $\begin{array}{l}\text { Forest Inventory Team: } 15-20 \text { students who met after school every Tuesday } \\
\text { Science Class: Tree tagging, measuring and identification; Plant unit at the } \\
\text { start of year } \\
\text { Site visits: Hoyt Arboretum, Stiegerwald refuge, Tualatin NWR, Willow } \\
\text { Creek with SOLV }\end{array}$ \\
\hline $\begin{array}{l}6^{\text {th }} \text { Grade FO } \\
\text { Control }\end{array}$ & $\begin{array}{l}\text { We will be doing ecology and possibly working outdoors towards the end } \\
\text { of the year. In April, for Earth Day, my classes take part in picking up } \\
\text { garbage around our school and down by the wetlands. }\end{array}$ \\
\hline $\begin{array}{l}7^{\text {th }} \text { Grade FO } \\
\text { Control }\end{array}$ & $\begin{array}{l}\text { My students have been going outside on a regular basis. We have } \\
\text { conducted plant, bird and wildlife surveys and investigated surrounding } \\
\text { areas. Much of my classroom and focus is on local ecology (ex. Raising } \\
\text { salmon and trout in classroom tanks, etc.) }\end{array}$ \\
\hline $\begin{array}{l}8^{\text {th }} \text { Grade FO } \\
\text { Control }\end{array}$ & No response given. \\
\hline \multicolumn{2}{|c|}{$\begin{array}{l}\text { Question: Have you seen your students share or teach with they have learned about the } \\
\text { environment with other people? Who? Examples? }\end{array}$} \\
\hline $\begin{array}{l}\text { Quinn / RC } \\
\text { Control* }\end{array}$ & $\begin{array}{l}\text { Some students have shared environment related learning with their science } \\
\text { fair project, others have talked to class about } 8^{\text {th }} \text { grade projects they are } \\
\text { doing. Science fair projects included a comparison of Doug firs at Forest } \\
\text { Park vs. Doug firs at our school. } 8^{\text {th }} \text { grade projects include ocean pollution, } \\
\text { wolf habitat, turtles and metro greenspaces. }\end{array}$ \\
\hline $\begin{array}{l}6^{\text {th }} \text { Grade FO } \\
\text { Control }\end{array}$ & No response given. \\
\hline $\begin{array}{l}7^{\text {th }} \text { Grade FO } \\
\text { Control }\end{array}$ & $\begin{array}{l}\text { Our students will often partner with other classrooms. Some student } \\
\text { 'leaders' will teach other students different topics or how to use certain } \\
\text { tools, etc.) }\end{array}$ \\
\hline $\begin{array}{l}8^{\text {th }} \text { Grade FO } \\
\text { Control }\end{array}$ & No response given. \\
\hline \multicolumn{2}{|c|}{$\begin{array}{l}\text { Question: Do your students speak of specific natural places that they like to visit? Which } \\
\text { places? Is there a sense of pride? }\end{array}$} \\
\hline $\begin{array}{l}\text { Quinn / RC } \\
\text { Control* }\end{array}$ & $\begin{array}{l}\text { Several students talk proudly about going back to visit places we have } \\
\text { taken them on site visits. This would include a wildlife refuge, Oaks } \\
\text { Bottom and Hoyt Arboretum. }\end{array}$ \\
\hline $\begin{array}{l}6^{\text {th }} \text { Grade FO } \\
\text { Control }\end{array}$ & No response given. \\
\hline $\begin{array}{l}7^{\text {th }} \text { Grade FO } \\
\text { Control }\end{array}$ & $\begin{array}{l}\text { Some. Most often it is local attractions like the beach or mountains. Many } \\
\text { use the Tualatin Hills Parks and Recreation Department areas in the } \\
\text { Beaverton area. Students also get involved with community happenings } \\
\text { such as Earthday, Slug fest (at THPRD nature park). I try to expose kids to } \\
\text { many natural areas as well through a focus on Oregon Field Guide } \\
\text { segments as warmups. }\end{array}$ \\
\hline $\begin{array}{l}8^{\text {th }} \text { Grade FO } \\
\text { Control }\end{array}$ & No response given. \\
\hline \multicolumn{2}{|c|}{$\begin{array}{l}\text { Question: What changes have your students made outside of school (at home, in their } \\
\text { community, etc.) because of their environmental work? Either reported from the students } \\
\text { or their parents? }\end{array}$} \\
\hline Quinn / RC & More than one group of students have told me they have removed invasive \\
\hline
\end{tabular}




\begin{tabular}{|c|c|}
\hline Control* & $\begin{array}{l}\text { species from their yards and their neighbor's yards based on what we have } \\
\text { done at school. }\end{array}$ \\
\hline $\begin{array}{l}6^{\text {th }} \text { Grade FO } \\
\text { Control }\end{array}$ & No response given. \\
\hline $\begin{array}{l}7^{\text {th }} \text { Grade FO } \\
\text { Control }\end{array}$ & $\begin{array}{l}\text { Many students stay involved with stewardship activities we started here at } \\
\text { the school. They often come back to check on their areas and trees we } \\
\text { planted. Some get involved taking high school ecology classes and or join } \\
\text { high school ecology/service related clubs. Some students have also } \\
\text { mentioned working on METRO projects (Ex. Oregon Beach Cleanup) }\end{array}$ \\
\hline $\begin{array}{l}8^{\text {th }} \text { Grade FO } \\
\text { Control }\end{array}$ & No response given. \\
\hline \multicolumn{2}{|c|}{ Question: Do you have any specific anecdotes of stewardship examples from your students? } \\
\hline $\begin{array}{l}\text { Quinn / RC } \\
\text { Control* }\end{array}$ & $\begin{array}{l}\text { Students are organizing for other students to attend community service } \\
\text { projects including ivy pulls and beach cleanups. I had one student who for } \\
\text { the last three years has continued to remove blackberries from his backyard. }\end{array}$ \\
\hline $\begin{array}{l}6^{\text {th }} \text { Grade FO } \\
\text { Control }\end{array}$ & No response given. \\
\hline $\begin{array}{l}7^{\text {th }} \text { Grade FO } \\
\text { Control }\end{array}$ & $\begin{array}{l}\text { Probably the best story was with my initial class of } 9^{\text {th }} \text { graders. They were } \\
\text { in my 'Field Biology' class as there were not deemed smart enough for } \\
\text { Chemistry or Marine Biology. They were alternative kids who needed a } \\
\text { different experience. I told them to all get raincoats and boots as we would } \\
\text { be outside everyday in the forest/stream area. Together we explored the } \\
\text { area and investigated it from a forestry and biology perspective. We } \\
\text { worked with the State Fish and Wildlife dept. to determine bird, amphibian } \\
\text { and mammal species living in the area. One day we went out and were } \\
\text { greeted by survey stakes. My students were outraged. This led to them } \\
\text { involving themselves fully into trying to save the forest from development. } \\
\text { They held fundraisers, got neighbors involved with a weekly newsletter, } \\
\text { worked with the county planners and eventually with the developer himself. } \\
\text { It was an incredible experience. For years afterward many of them would } \\
\text { come by and check on the area and stop by to let me know about anything } \\
\text { they found 'out of place'. }\end{array}$ \\
\hline $\begin{array}{l}8^{\text {th }} \text { Grade FO } \\
\text { Control }\end{array}$ & No response given. \\
\hline \multicolumn{2}{|c|}{$\begin{array}{l}\text { Question: If applicable, please give me a detailed explanation of your long-term ecology } \\
\text { projects you have carried out with your students (duration, work the students did, where } \\
\text { the project took place, etc.) }\end{array}$} \\
\hline $\begin{array}{l}\text { Quinn / RC } \\
\text { Control* }\end{array}$ & $\begin{array}{l}\text { One long term project is our Willow Creek SOLV site work. This has been } \\
\text { going on for } 7 \text { years and has included invasive species removal, water } \\
\text { quality monitoring, turtle habitat restoration, planting of over 1,000 native } \\
\text { plants and plant monitoring }\end{array}$ \\
\hline $\begin{array}{l}6^{\text {th }} \text { Grade FO } \\
\text { Control }\end{array}$ & My $6^{\text {th }}$ graders have not done a stewardship project this year. \\
\hline $\begin{array}{l}7^{\text {th }} \text { Grade FO } \\
\text { Control }\end{array}$ & $\begin{array}{l}\text { I have looped with my students in } 2 \text { year cycles. This has allowed me to } \\
\text { plan out a way to investigate the natural areas over a longer period than } \\
\text { normally available and in turn given students more ownership in the areas } \\
\text { we study. These are the major projects we are involved with: } \\
\text { Tree Planting: much of our forest and wetland areas have been developed. } \\
\text { With each class we investigate the area and then create plans to naturally } \\
\text { re-establish areas that have been cleared or have invasives to bring it back } \\
\text { to a more natural state. We plant native plants in these areas and over a } 2 \\
\text { year process study how effective it has been. } \\
\text { Wetland Monitoring: students are assigned a section of Willow Creek to }\end{array}$ \\
\hline
\end{tabular}




\begin{tabular}{|l|l|}
\hline & $\begin{array}{l}\text { study and monitor. We perform the EPA's Stream Walk data collection and } \\
\text { then students learn of different ways to monitor health (macroinvertebrate } \\
\text { studies, population density, carbon storage, invasive species, etc.). They } \\
\text { then continue to investigate their area regularly throughout the year(s). }\end{array}$ \\
$\begin{array}{l}\text { Bird Studies: using the Project Feederwatch from Cornell University as a } \\
\text { basis, we conduct winter bird population surveys in the school and wetland } \\
\text { areas. This too is an ongoing activity. }\end{array}$ \\
\hline $\begin{array}{l}8^{\text {th }} \text { Grade FO } \\
\text { Control }\end{array}$ & \begin{tabular}{l} 
No response given. \\
\hline
\end{tabular}
\end{tabular}

*The students in the experimental group and in the RC control took part in all of the same projects and fieldwork, they just had different lead teachers. 


\title{
APPENDIX C: HUMAN SUBJECTS DOCUMENTATION
}

\author{
Appendix C.1: 2009-2010 Human Subjects Form \\ Teaching Ecosystem Complexity through Field Science Inquiry
}

1A- Project prospectus: Our program will develop, test, and disseminate guidelines for a two-week teacher training workshop lead by Professional Development Providers using supplementary webbased material for conducting ecological research projects. Professional Development Providers (PDP) are defined as teams of scientists, science educators, and experienced teachers who provide in-service teacher training at nature centers, botanical gardens, city park departments, state and federal land management agencies, universities, and Long Term Ecological Research (LTER) sites (other than the five sites collaborating on this project). Web-based materials consist of activities and resources that will facilitate transference of the teachers' science research skills to the classroom. The proposed training manual will be built upon the collective experiences of five teams of scientists and educators at geographically distinct LTER sites in Oregon, Colorado, New Mexico, Phoenix, Arizona, and Puerto Rico. Between 16 and 18 new teams of Professional Development Providers will receive training in the use of the materials and subsequently will field test the materials with their own groups of teachers. We will measure how effectively the materials promote teacher confidence, knowledge, science inquiry skills, and understanding of ecological complexity. Participating teachers will help us measure how effectively their students gain ecological knowledge and inquiry skills. Another goal of the project is to increase the participation of Spanish-speaking students in the field of ecology. This program will provide teacher training and infusion of resources in Spanish to serve the growing proportion of Hispanic students.

During this last project y ear, we will test how effectively this strategy increased student interest in science, student stewardship attitudes, and student understanding of ecology.. Project evaluation will be carried out cooperatively between project staff and Dr. Joan La France. This evaluation was required by NSF in order to provide feedback about each aspect of the program. In addition, some of the results have educational research potential and will provide us with data to be submitted to peerreviewed journals for possible publication. All survey instruments described will be developed over the first year of the grant. We will submit all of the instruments to the HS Review board for review and approval before any of the instruments are utilized.

Students: Work samples (ecosystem models and science reports) from participating classes will be submitted and rubrics will be used to evaluate these samples to determine the ensuing changes in student learning (e.g., Do students understand complexity using their models? Do their science project reports show adequate application of inquiry?) Science Inquiry Skills Rubric: prompts and rubrics adapted from the Oregon State Science Inquiry guide will be used to assess science reports for the 4 key aspects of science inquiry: posing a question, designing a study, choice of data analysis, and quality of data interpretation. Ecosystem Model rubrics: will be developed to assess the degree to which student's explanations of their understanding using their models represent an increased understanding of ecological complexity. Most of the student data will be used by the instructor for their grade in the class and subsequently by the evaluators. Student Science Interest Survey: A pre- and post-study survey of students of participating teachers will assess perceived benefits to students, their level of interest in ecology, and the usefulness of the Spanish-language materials to Hispanic students. In addition, a Student Stewardship questionnaire will

Once parental consent has been received, the student would then use a password to log on to the site on the computer where their questionnaire is provided. If the participating teacher could not obtain enough permissions, he or she could then modify our survey with his/her own questions that are directly related to their own learning goals for the class ecology program. The teacher would provide us with their own anonymous results. We would at least be able to obtain some feedback about student preferences. 
II- Exemption Claim: According to HSRRC regulations, we cannot claim an exemption. A similar project; Teachers in the Woods, was reviewed and approved by the HSRRC committee 5 years ago.

III- Subject Recruitment: Experienced science teachers will be recruited to our program by the following methods: electronic list-servers, printed newsletters to access members of state level science-teacher organizations, the NSTA list-serve, teacher training college job listing networks in the region, and at regional science teacher conferences. Project staff will mail flyers to science faculty at schools and districts who have shown a previous interest in professional development opportunities. Teachers from schools having a majority of Spanish-speaking students will be recruited through their professional organizations. All participants in this program will have volunteered to do so. During the first scheduled meeting day of the program, all teachers will be informed about all the components of the program assessment. Participation in the program is not predicated by teachers' participation in the evaluation. The PI will grant those who do not wish to participate in any aspect of the evaluation an exemption.

IV- Informed Consent: An informed consent form will be provided to all teachers after the discussion described above. A copy of the form we will use is provided.

V- First person scenario about the evaluation/research aspect of this project:

Teacher: During the first day of the summer program, to which I had applied and been admitted, a project staff member addressed our group with an overview of the purpose of the evaluation. After agreeing to participate and signing the consent form, I was given the first teacher survey to fill out. During the summer program I participated in a one hour interview about the ecology models I had made during the training program. At the end of the summer program, I was asked to fill out a brief form evaluating how the summer program went for me.

Then, I was given a student evaluation kit, to begin in the fall before my students begin their field science projects. I was given adequate time to read through the kit and ask any questions. I was made to understand that all student identification information would be kept confidential. The evaluator explained that student surveys would be conducted in the fall and again in the spring, and that I was to collect student work samples in the spring that would be appraised in the use of science inquiry and ecological complexity using criteria that was then given out for each of us to review.

Over the school year I was sent and completed additional survey forms. I passed out and collected parent consent and student assent forms of students interested in participating in the study. I collected, photocopied, and removed student identification from a few work samples that I sent to the researchers. These work samples were selected from the pool of students that returned parent consent and student assent forms. I also administered two surveys to my students who completed consent and student assent forms. This survey examined student interest in ecology. After the evaluation was completed, I was sent a summary of the results from the entire group to the evaluator via the internet.

Student: My science teacher gave us a letter to take home to our parents. The letter was from some people at Portland State University. The Portland State University people want to see if the actives I participated in during class affected my interest in ecology. To do that, they want to have me and other students in my class fill out two surveys. They also wanted to look at my science project write up and ecology models from class. I took the letter home to my Dad/Mom, who read it over with me. We both signed that it was okay for the Portland State University people to give me a survey and to look at my school work. I took the signed portion back to my teacher. My teacher gave us a survey that asked about our interest in ecology. We did a field project with our class that was lead by my teacher. Near the end of the year my teacher gave us another survey with more questions about our interest in ecology. 
VI- Potential Risks and Safeguards: There are only minimal potential risks involved in participating in this evaluation. These include possible inconvenience due to the time it will take to fill out the forms and possible risk of embarrassment from participation in an interview.

VII- Potential benefits: The primary goal of this proposed program is to accelerate the adoption of inquiry field research-based approaches to ecology education. Results from this study can be used to develop a greater understanding about what is required to support teachers in utilizing ecological inquiry in their practice. Secondarily, the goal is to increase the integration of ecology into the curriculum of high school science classes. The potential impact of increased public understanding of the science behind the question of the future of our forests is immense.

VIII- Records and Distribution: All information collected will be kept confidential. All forms, including the consent forms initially signed by participants, will be kept in a locked file cabinet by Dr. Dresner at the PSU campus. Original student information that contains students own names will be kept in a locked file cabinet at the teachers own classroom, copies of the student data encoded with a pseudonym or number will be used only by the PI or Co-PIs. Under no circumstances will information about any individual teacher or student be used so as to violate their confidentiality. These records will be kept on file for three years after completion of the study.

IX- Appendices: All informed consent forms are included below.

\section{Teaching Ecosystem Complexity Evaluation Teacher Consent Form}

As a participant in the Teaching Ecosystem Complexity program this summer, you are also being asked to participate in a valuable evaluation of the program. As you know, the purpose of the program is to provide you with an opportunity to learn to incorporate science inquiry, field ecology, ecological modeling, and the study of ecological complexity into your teaching. The project staff has developed surveys about teaching science inquiry and ecological knowledge that you will be asked to fill out. We have also developed student assessment rubrics with which we will score your student project work and student generated ecological models. Lastly, we have developed student interest surveys.

You will be asked to fill out a series of survey forms, and you will be asked to take part in an informal discussion concerning the progress of your work with a member of the project staff. Some of the evaluation forms will be completed during the 2 week summer session, taking about 1 hour. Teacher interviews will take place during summer workshop for less than 1 hour. Additional survey forms will be completed during the school year, taking a total of about 3 hours. In addition, during the school year, you will be asked to collect and submit student work samples showing your students' progress in field ecology work, understanding of ecological complexity, and use of ecological models. These will be scored by us using the rubrics we have developed. You will also be asked to conduct the survey of student interest in science, which will be provided to you on the computer. Some of the benefits of participation in this aspect of the program include your own insights gained as you change as a professional during the course of your participation in this project. Also, this study will help the project staff continue to make revisions in the program to benefit future participants. Lastly, the results of this study will help accelerate the adoption of ecology research-based teaching.

Any risks involved with participating in this evaluation are minimal. It may be inconvenient for you to take the time to fill out the forms. The project staff has informed you about their willingness to answer any questions you might have about this evaluation. All information you provide regarding this evaluation will be kept confidential. Your participation is voluntary, and if you choose at any time not to participate in this evaluation and you are taking this for graduate credit, it will not affect 
your grade. Your signature indicates that you have read and understand the above information and agree to take place in this assessment. By signing, you do not waive any legal claims, rights or remedies. You will be provided with a copy of this form.

Signed:

Date:

If you have any questions or concerns about this evaluation, please contact Dr. Marion Dresner at dresnem@pdx.edu or 503-725-5961, or the Chair of the Human Subjects Committee, Research and Sponsored Projects, 111 Cramer Hall, Portland State University, Portland, OR 97207, Telephone 503-725-4288.Hsrrc@lists.pdx.edu

\section{Parent Consent Form}

Your child is invited to participate in a study conducted by a group of universities, lead by Dr. Marion Dresner from Portland State University. The researchers hope to gain a better understanding of how students' interest in and knowledge about ecology change when they participate in a teacherlead field project. Your child was selected as a possible participant in this study because his/her science teacher was a participant in the Teaching Ecosystem Complexity summer training program. Every student in your child's science class will be invited to participate in this study.

If you and your child decide to have your child participate, your child will be asked to fill out two surveys. Each survey should take about thirty minutes and will be administered to all participants at one time during school hours by your child's science teacher. In addition, your child's science teacher may make photocopies of science reports and ecology modeling work done by a few randomly chosen students during regular science class. The student name/identification will be removed and the copies will be sent to the researchers. The researchers will score the student work using rubrics to measure understanding of science inquiry skills and understanding of ecosystem complexity. The survey and work samples will provide information to the researchers and your child's teacher about the usefulness of their field ecology program in helping them to learn more about how scientific knowledge is constructed.

Any risks involved with participating in this evaluation are minimal. While participating in this study, it is possible that your child may feel bored, overwhelmed, or concerned about the repercussion of his/her answers. In order to safeguard against this your child will be reminded that his/her responses on the survey will not affect his/her grades in any way. You and your child may not receive any direct benefits from taking part in this study. However, the study may help to increase knowledge about how students learn ecology, which may help future students.

All results will be anonymous. Your child's science teacher will collect and keep all survey responses in a locked filed cabinet. The teacher will send the researchers the completed surveys without any information that identifies the name of the child who completed the survey. Your child's participation is voluntary. Your child does not have to take part in this study, and it will not affect your child's grade or relationship with his/her science teacher or with Portland State University. Your child may withdraw or you may with draw your consent at any time without affecting his/her grade or relationship with the researcher or with his/her science teacher. Your signature indicated that you have read and understand the above information and agree to allow your child to take part in this study. By signing, you do not waive any legal claims, rights or remedies. You will be provided with a copy of this form.

\section{Signature}

If you have any questions or concerns about this evaluation, please contact Dr. Marion Dresner at dresnerm@pdx.edu or 503-725-5961, or the Chair of the Human Subjects Committee, Research and Sponsored Projects, 111 Cramer Hall, Portland State University, Portland, OR 97207, Telephone 503-725-4288. 


\section{Teaching Ecosystem Complexity}

Student Assent

\section{Student's name}

Your parent or guardian has said that it is okay for you to take part in a project about your interest in ecology. If you choose to do it, you will be asked to fill out two surveys. Each survey should take about thirty minutes. Your responses on the survey will not affect your grades at all.

If you want to take a break and rest, or stop completely, just tell your science teacher - you won't get into any trouble. In fact if you don't want to do it at all, you don't have to. Just say so. Also, if you have any questions about what you will be doing, just as your science teacher to explain.

In addition, your science teacher may photocopy some work done during your regular science class by a few participating students. Your name will be removed and this copy will then be sent to the researchers.

If you do want to try it, please sign your name on the line below. 


\section{Appendix C.2: 2010-2011 Human Subjects Form}

\section{P Portland State}

Human Subjects Research Review Committee

Post Office Box 751

$503-725-4288$ tel

Portland, Oregon 97207-0751 503-725-3416 fax

hstrciolists. pdx,edu

December 10,2010

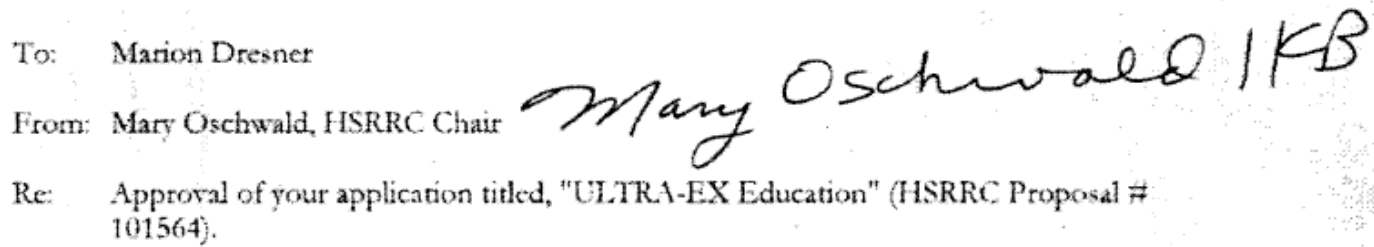

Dear Marion,

In accordance with your request, the Human Subjects Research Review Committee has reviewed your proposal referenced above for compliance with DHHS policies and regulations coreting the protection of human subjects. The committe is satisfied that your provisions for protecting the rights and welfare of all subjects participating in the research are adequate, and your project is approved. Picase note the following requements:

Changes to Protocol: Any changes in the proposed study, whether to procedures, survey instruments, consent forms or cover lettets, must be outlined and submitted to the Chair of the HSRRC immediatety. The proposed changes cannot be implemented before they have been reviewed and approved by the Commintec.

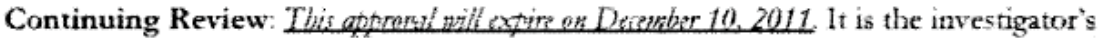
responsibility to ensure that a Continuing Review Report (available in ORSP) of the status of the project is submitted to the HSRRC two months before the expimaion date and that approval of the study is kept current.

Adverse Reactions: If any adverse reactions occur as a result of this study, you are required to notify the Chair of the HSRRC immediately. If the problem is serious, approval may be withdrawn pending an investigation by the Commitree.

Completion of Study: Please notify the Chair of the Human Subjects Research Review Committee (campus mail code ORSP) as soon as your research has been completed. Srudy records, including protocols and signed consent forms for each participant, must be kept by the investigator in a secure location for three years following completion of the study

If you have questions or concerns, please contact the HSRRC in the Office of Research and Sponsored Projects (ORSP), (503) 725-4288, 6th Floor, Lnitus Building, 4h \& Lincoln.

Ce: Inda Geotge 